


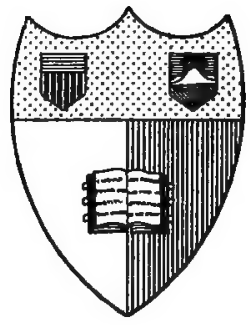

\section{Avem 3 gark \\ State Gallege of Agriculture}

At Ofornell 3tninergity

Jthaca, 封.

\section{Jibrary}




\section{Cornell University Library}

Wild creatures of garden and hedgerow,

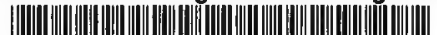




\section{Cornell University Library}

The original of this book is in the Cornell University Library.

There are no known copyright restrictions in the United States on the use of the text. 




\section{WILD CREATURES OF GARDEN AND HEDGEROW}


SOME BOOKS DEALING WITH NATURAL HISTORY

THE FLOWER AND THE BEE By JoHN M. LovelL. Illustrated. ros. 6 d. net.
A popular exposition of pollination
for Gardeners, Bee Keepers, and all Lovers of Nature.

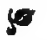

PLANTS AND THEIR USES

An introduction to Botany by F. Leroy SARGENT. $\quad 3^{84}$ Illustrations. 7 s. 6d. net.

\author{
$s$ \\ ERNEST THOMPSON-SETON \\ BIOGRAPHY OF A SILVER FOX \\ MONARCH THE BIG BEAR \\ ROLF IN THE WOODS \\ BOOK OF WOODCRAFT \\ ARCTIC PRAIRIES \\ ANIMAL HEROES
}





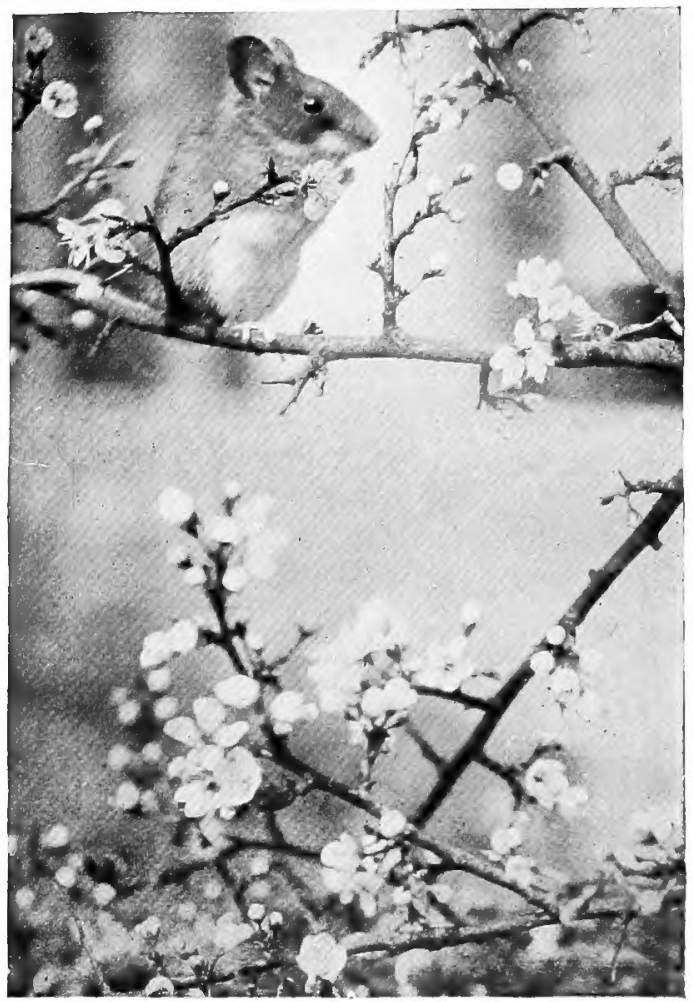

Frontisptece

THE LONG-TAILED FIELD MOUSE

A mouse up aloft among the wild plum blossom 




\title{
WILD CREATURES OF
}

\section{GARDEN AND HEDGEROW}

\author{
BY \\ FRANCES PITT
}

NEW YOR K

DODD, MEAD AND COMPANY

1920 
WILD CREATURES OF GARDEN AND HEDGEROW different things that we see happening daily. We want facts, and the descriptions that are given hereinafter are almost entirely the observations and notes made while watching the creatures in question; and any value these studies may possess will, I believe, be found due to the fact that they are records at first hand of what has been thus seen and learnt. Four chapters have previously appeared as essays in the National Reviero, to the Editor of which, Mr. L. J. Maxse, I am indebted for kindly allowing them to be republished herein.

FRANCES PITT. 


\section{CONTENTS}

CHAP.

I. BATS.

II. THE BANK VOLE . $\quad$ - $\quad$ - $\quad$ - $\quad 24$

III. TWO COMMON BIRDS . . . 45

IV. SHREWS . $\quad$ - $\quad$. $\quad$. $\quad$. $\quad$. 71

V. TOADS AND FROGS $\quad$ - $\quad$ - $\quad$. 95

VI. THE LONG-TAILED FIELD MOUSE • . 118

VII. 'THE LITTLE GENTLEMAN IN THE BLACK VELVET COAT'

VIII. THIEVES OF THE NIGHT — $\quad$ • $\quad 166$

IX. SOME GARDEN BIRDS . . . . 192

X. THE HEDGEHOG . . . . . 214

XI. THREE COMMON REPTILES • . $\quad 239$

XII. THE SHORT-TAILED FIELD VOLE • . 260 



\section{LIST OF ILLUSTRATIONS}

The Long-Talled Finld Mouse

Frontispiece

Long-Eared Bats Asleep . . . . To face page 6

Long-Eared Bats Awake. . . . .

Pipistrelle about to take Flight . . " 6

Thirteen Long-Eared Bats . . . . ” 16

Bank Voles-'Stolen Goods" . . . . " 36

Bank Voles-'ON the Alert" . ., 96

Young Song Thrush-'Waiting' . . " " 54

Young Song Thrush-'Is that Mother

Coming?" . . . . . . . . $\quad$, 54

Blackbird on Her Nest . . . . . . , 64

The Pigmy or Lesser Shrew . . . . "

The Water Shrew . . . . . . . .

A Toad Climbing $\quad . \quad$. $\quad . \quad . \quad . \quad . \quad 100$

The Long-Tailed Field Mouse (2 Photographs) " 128

The Mole (2 Photographs) . . . . " 144

'Whiskers' and Old Puss . . . ” 174

An Old English Black Rat Busy Eating " 186

A Common Brown Rat with a Hen's Egg " 186

The Great Tit Carrying Home Food ror ITS Young. . . . . , 210

A Hedgehog Family-the Mother Rolegd UP " 234

A Hedgehog Family-the Old Hedgehog UNROLLS . . . . . . . " 234

The Harmless Grass Snake . . . . "244

The InNocent BuINDWorm. . . . . . " 244

The Meadow Vole or Short-Talled Field Mouse (3 Photographs) . . . . 264 



\section{CHAPTER I}

BATS

Go out any warm still evening into your garden, whether it be a town or country one; wait and watch for a few minutes, and as the light begins to fail you will see the shadowy shapes of the bats wheeling and turning against the sunset sky. There are big ones and little ones, tiny things flittering up and down the hedgerows, bigger ones flying round the trees, and larger still dashing by high overhead with strong purposeful flight. Strange shrill squeaks fill the air as they turn and twist and chase one another, tumbling sometimes through the air as if romping and playing together. So high is the note, so shrill the voices, that many people cannot hear the bats calling to one another; they stand and listen and do not hear a sound, yet the evening air will be full of tiny voices, of high-pitched squeaks, as the little 'flittermice' race and chase the moths and other night-flying insects to and fro. 


\section{WILD CREATURES OF GARDEN AND HEDGEROW}

Some persons call them 'leathery-bats,' others 'flitter-mice,' but neither name is a good one, for they are not mice, nor are their wings at all leathery. The wing of a bat is really a very wonderful thing. It is a hand with long fingers, between which the skin has been drawn out so as to make the membrane of the wing. If you spread out your hand, and imagine the four fingers pulled out and grown until very very long, while the thumb remains short and stumpy, and that the skin between the fingers has also grown and been stretched until it extends not only from tip to tip of the fingers but along the side of the body to the hind foot, you will understand how a bat's wing has become what it is. It is simply a much changed and developed hand, the bones of this hand acting like the ribs of an umbrella and serving to keep the skin stretched and taut when the owner is in flight. When the bat alights it folds up its hands, the skin falls into wrinkly folds, and, using the thumb joint as a fore foot, it is able to run about almost as quickly as a mouse. The skin of the wings extends along the side of the body, is attached to the hind leg, and then joins the tail, thus making a rudder with which the bat steers itself when flying; 
also, when the tail is curved upwards, forming a sort of pouch, but of the use of this pouch more presently.

'Flitter-mouse' is hardly a better name than 'leathery-bat,' because, as I have already said, bats have nothing whatever to do with mice; they are not, as some people think, mice with wings, but all the same they are mammals. By mammals is meant creatures which suckle their young. If you can find or catch a bat you will see it is not a bit like a mouse, even its soft delicate grey or brown fur is longer and more silky; but it is in the shape of its skull and teeth that the greatest differences lie. In the front of the mouth of a mouse or rat you will see two pairs of sharp-edged cutting teeth, or incisors, between which and the molars or grinding teeth there is a considerable gap. In the bat's tiny mouth will be seen pointed teeth arranged evenly all round, totally different from the peculiar cutting teeth of the Rodents, as mice, rats, and rabbits are called.

So bats are just bats, and have nothing to do with anything else. Very quaint, curious, and wonderful little creatures they are too, besides which they do a great deal of good, for they live entirely upon insects, eating great numbers, 
and take up at dusk the work on which the swallows have been busy all day, i.e. that of chasing and catching flies and gnats. Any evening when it is warm enough for them to be out and about you will be able to see how hard they work. How they flitter, flutter, dash, and turn, until in the failing light it makes one almost giddy trying to keep one's eyes on the little grey forms that appear and disappear, whirling round one's head, vanishing into the shadows, darting out again, rustling past with beating wings, again to disappear along the hedgerow or round the rose-bushes. But as the dusk deepens into darkness, as it becomes more and more difficult to see, when only ghost-like white moths can be made out in the gloom, when the brown owl's hoot rings startlingly loud through the night, it will dawn upon you that the rustling wings have gone, that the high-pitched squeaks are no longer to be heard-in short, the bats have vanished! The explanation is simple enough. The majority of bats do not keep on the wing all night; they only fly for a short time at sundown and at dawn, spending the night in their snug homes, generally a crevice in an old building or a hole in a tree. During their short flights they 
gorge themselves with insects, feeding twice in the twenty-four hours-a good supper in the evening, a good breakfast in the morning; but to see the daybreak flight you must be up early, before the sun, for they are off home to their hiding-places as soon as the light gets strong.

When watching bats on the wing, the first thing that strikes you is that there are big and little ones, some much bigger than the others, flying straight and strong like birds high in the sky, while the medium-sized ones fly lower, and the smallest flitter and flutter round the bushes. They are not old and young ones, or anything of that sort, but different kinds, for we have no less than twelve sorts of bats in this country. The commonest are the pipistrelle, or 'flitter-mouse,' the one which seems to fly so weakly; the noctule, or great bat, the high-flying one, which is much bigger; and the long-eared bat, which is of a medium size, and flies in and out about the trees. The latter can be known at once, as it has such very long ears, almost as long as its body; no other British bat has ears anything like them. When not in use these ears are curled up and tucked back under the wings for safety, only 
a piece of skin or membrane, that is situated inside the ear, and looks just like a second one, remaining on view. This false ear or 'tragus' is so like a proper ear that the bat looks as if it had a second pair. It is only while the owner is asleep that the real ears are tucked away; as soon as it wakes up they are drawn out, uncurl, and come forward. They are most wonderfully sensitive delicate organs, contracting and withdrawing, then being extended again, something after the manner of a snail's 'feelers.' For instance, if you put your finger near one of these bats it will, though the hand has not touched it and it could not have seen the approaching finger, draw back at once the ear on that side. As the long-eared bat is fond of hunting round trees, and in and out between the branches, its extraordinarily sensitive ears must be a great help to it, enabling it to dodge between the twigs and know where the moths and flies are. It undoubtedly depends chiefly on its ears when hunting, though it has a pair of sharp keen little eyes with which it can see well. How the old saying 'blind as a bat' came into being I cannot think, for all bats can see well. Certainly their eyes are not very big, but they are there all right, and are thoroughly useful 

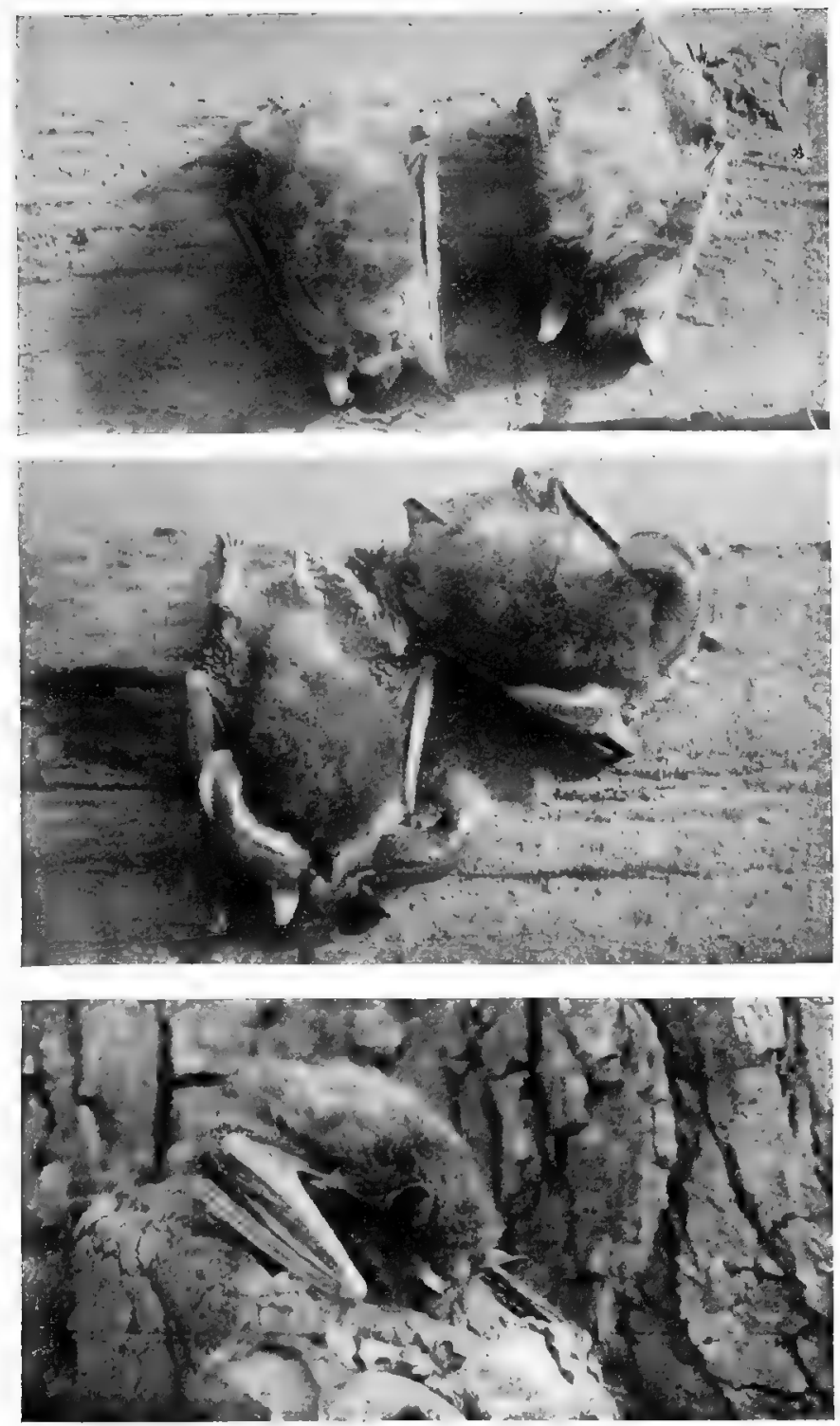

\section{BATS}

No. I, Long-eared Bats asleep: note the long ears tucked away

No. 2. Long-eared Bats awake: note the great ears waving to and fro

No. 3. Pipistrelle about to take flight

(Nos. $x$ and 2 are $\frac{1}{3}$ life size, No. 3 life size) 

eyes too! But such strange things are believed sometimes that it is no wonder that mistaken ideas get about concerning little-known creatures like bats. I have heard girls scream because a bat flew by them and they thought it wanted to alight on their head, where it would get entangled in their hair and they would never get it out. Of course the idea is pure nonsense, the little creature being even more afraid of them than they were of it, and with as little wish to get tied up in their hair as they had to have it there. As a matter of fact all the bats found in this country are perfectly harmless, being unable to hurt anything bigger than an insect. Even the biggest, the noctule, could not hurt one much, even if it tried, for its teeth are not big enough to do any real damage. A fine noctule that I had taken out of a hole in a tree did try to bite me, snapping angrily at my fingers like a little bull-dog, but even it did not draw blood.

It is usually rather difficult to find the hidingplaces where bats sleep, but this noctule let everybody into his secret by falling out with his friends. I was walking under an old willow tree, when a continuous shrill squeaking made me look up. It undoubtedly came from 
above and it was as undoubtedly made by bats. There were two or three holes some way up the tree that had been made by the greenwoodpecker, and it was evident that the bats were living in them. I soon brought a ladder and got up to the holes; the squeaking came from one of them, which was also marked by a peculiar musty smell which belongs to this kind of bat. It sounded like a family quarrel, for they were squeaking most furiously : however, they talked even more angrily when, having enlarged the hole a bit, I was able to put my hand in and pull them out. One by one I popped them into a muslin bag, wherein they were safe and could not get away, for I wanted to photograph them, which was the reason $I$ had taken so much trouble to get them out. There were four of them, one being a brighter brown in colour than the others. This was the male, the other three being females. The ladies were duller, their soft silky fur being a subdued brown. They were all about the same size, having a wing expanse of a little over fourteen inches. They scrambled about, one over the other, seeming in a very bad temper at the fix they had got into, snapping and biting and squeaking angrily. At last, the photographs 
having been taken, I was able to let them go, when they darted away swiftly, flying high up over the trees and soon being lost to sight; for bats, like owls, though they are creatures of the night, can see perfectly well in the daytime and are by no means dazzled by sunlight. I have even seen a long-eared bat hunting in bright sunshine on a warm spring day. It was about twelve o'clock, and there was this bat hawking and turning and twisting as happily as if it were evening !

Another noctule I kept for some days, though all bats are extremely difficult to feed and look after. It was brought to me by some children who had found it in a sleepy condition, but when brought into the warm room it began to revive. By evening it was quite lively, so I tried to feed it. It was too early in the year to get any insects, so I offered it very small bits of meat, no bigger than a pin's head, on a pair of forceps. It snapped at the forceps, seemingly from anger and annoyance, but its teeth closed on the morsel of meat. Finding the meat in its mouth the bat turned it over and over, chewed it thoughtfully for some minutes, and finally swallowed it. It ate three more bits, then refused morsel after morsel. It took them 
off the forceps, turned them over in its mouth, spit them out, or wiped them off its tongue on to the twig on which it was sitting. It did it something after the manner of a bird wiping its beak.

It is wonderful how particular bats are about their fur, licking and dressing it most carefully with their tiny pink tongues; indeed they are really most dainty creatures, and I became very fond of a tiny pipistrelle that I kept for a time in order to learn something of its ways. Though some people think bats repulsive creatures, any one who had watched it would soon have changed their opinion. It was daintily clad in soft, silky, brown fur, which was an even tint above and below. Its movements were very quick, and it could run like a mouse. It could move almost as fast backwards as forwards, indeed when climbing up a stick seemed to prefer to shuffle up backwards. Of course it is no hardship to a bat to have its head lower than its tail, for when at rest they always hitch themselves up by their hind feet and hang head downwards. At first this bat was much annoyed when touched, squeaking vigorously, and continuing to do so long after the offending hand had been taken away. As 
it seemed so annoyed I left it alone, and having explored the cage it at last tucked itself away behind a dry sod of earth that was propped up against one side. This was October 11th, a time when all bats are preparing for their winter sleep, for bats, being insect-feeders, have to hibernate during the cold months when flies are not to be had. Some of them sleep through the winter, remaining cold and unconscious in their hiding-places from October to April until the spring weather calls them to life again; but the slumber of the pipistrelle is not so sound, and $I$ have seen them on the wing on mild days even in mid-winter. For instance, in $\mathbf{1 9 1 7}$ I saw pipistrelles out hunting on November 15th, 16th, January 18th, 22nd, and 25th. Like all animals which sleep for considerable periods, bats get very fat in the autumn, this store of fat serving them in the place of food during the long months that they are hidden away. By spring it is all used up, and they have become quite thin.

My little pipistrelle remained cold and unconscious for three days, when the weather getting warmer it woke up. I made a collection of flies and spiders and tried to feed it. It snapped at a big bluebottle and munched 
it up with great relish, but stopped eating whenever it heard the slightest sound, and seemed very shy and nervous. It would not touch the spiders nor a woodlouse, and I afterwards found that it did not like either, only eating flies with any enjoyment. The next evening it was again very lively, and seemed much less afraid, taking flies readily from my fingers. It would only eat quite fresh ones, and turned away in disgust from those that had been killed the day before. The following day it was even tamer, eating happily while sitting on my hand, which much increased my respect for its intelligence, for it is only creatures which have brains which learn by experience, and this little bat had already, though so much afraid at first, learnt that I meant it no harm and that it could trust me. It no longer squeaked frantically when touched, or opened its little mouth in defiance. Instead, it sat on my hand eating all the flies that it could get. Twelve house flies, two bluebottles, one drone fly (that large brown fly which looks just like a hive bee, but is really nothing of the sort), and a large gnat. The big drone fly gave it a lot of trouble. First it chewed its head off and dropped the body, which I picked up and 


\section{BATS}

returned. Then it ate the thorax, taking care to let the wings fall, and dropped the abdomen, which I picked up, when it finished off its meal. In one case when it dropped part of a fly it began to search my hand for it and bit me quite hard! Of course its tiny teeth could not make any mark, yet it gave quite a respectable pinch. It appeared to smell and not to see the flies, and no doubt it was the scent of flies on my fingers that made it make the mistake. It was most amusing to see the way it licked its lips with its tiny pink tongue after each morsel, as much as to say, 'Wasn't that good!' All the smaller flies were eaten up completely even to the wings, but in the case of the larger ones the wings were bitten off and dropped. One of its troubles when eating was that it was not used to dealing with flies while sitting still. All bats feed when on the wing: they chase their prey, catch it, eat it then and there, and dash on after the next fly or gnat as the case may be. It sounds rather a difficult thing to dispose of your food when dashing through the air as hard as you can go, and it is by no means easy to see how bats manage it; but if you watch them carefully when they are hawking to and fro you will get some idea of the clever way in 
which they do it. First, it must be remembered that the skin or membrane of a bat's wing stretches from the 'fingers' to the 'ankle' of the hind foot, and from the foot to the tip of the tail. When the tail is brought forward under the body the skin on either side forms a pouch or bag. It is called the interfemoral membrane and the interfemoral pouch, the word 'interfemoral' really meaning 'between the thighs.' Now when a bat is flying along and grabs an insect it drops its head down into its pouch, where its prey cannot escape, and, still flying, crunches it up. The whole thing is done so quickly that it is very hard to follow, but when watching bats in the twilight you will often see them make a dash after an insect, and then apparently tumble through the air for a foot or two. This is when the pouching is taking place, and if you are very sharp-eyed you may even see more or less what the bat does. My. little pipistrelle had hitherto caught and pouched all its food when on the wing, and from habit felt compelled to try and pouch the flies I gave it, though sitting in an attitude that made this almost impossible. The result was that time after time it tumbled over, and would right itself 14 
with such a puzzled and bewildered look! However, the difficulty of doing the proper thing did not stop it eating. It had a tremendous appetite, and I was hopeful of keeping it safely through the winter and letting it go again in the spring. Insects were now scarce out of doors, but in an attic window I could find plenty of flies. The bat made nothing of twenty to thirty at a meal, and one evening ate no less than fifty ! They were chiefly house flies and 'greenbottles.' It was decidedly 'full-fed' and sleepy after this meal. It was now November, when it ought to have been hibernating, and to get it to go to sleep I kept it in an unheated room, but day after day it continued lively. Sometimes it would hang itself up in a corner of its cage, and, resting head downwards, with wings tucked to its sides, sleep for twenty-four hours, but the middle of November came without it really hibernating. Then a day passed, and another, and it remained quiet in its corner. I thought it was really asleep at last, and that I should get it through the winter all right, but alas! the sleep was too sound! Something about the little form made me suspicious: I touched it and found it cold with a chilliness which was 
not that of the lowered temperature of the winter sleep-the poor little pipistrelle was dead!

Though most bats are gregarious in the summer-that is to say, live together in parties sometimes numbering scores, and even hundreds-yet in the winter they prefer solitude and quiet. They go off singly, or at the most in twos and threes, to snug holes and crevices in rocks, old buildings, and trees. An example of this was the thirteen long-eared bats found in a barn; with two exceptions, where there were couples together, they were hidden singly under the rafters. As this was in mid-October there is no doubt these were their hibernating quarters. I kept one of them for a few days so as to learn something of its habits. It was really a beautiful little animal, with its silky grey fur, quaint face, and long sensitive ears, which seemed to throb and quiver with life. There is a row of stiffish hairs along the outer margins of the ears which, after watching this bat, I am inclined to think is a help to it in threading its way among twigs and leaves. Like the pipistrelle, the long-eared bat soon learnt to take flies well. The first that I offered it, a greenbottle, it grabbed eagerly, 16 


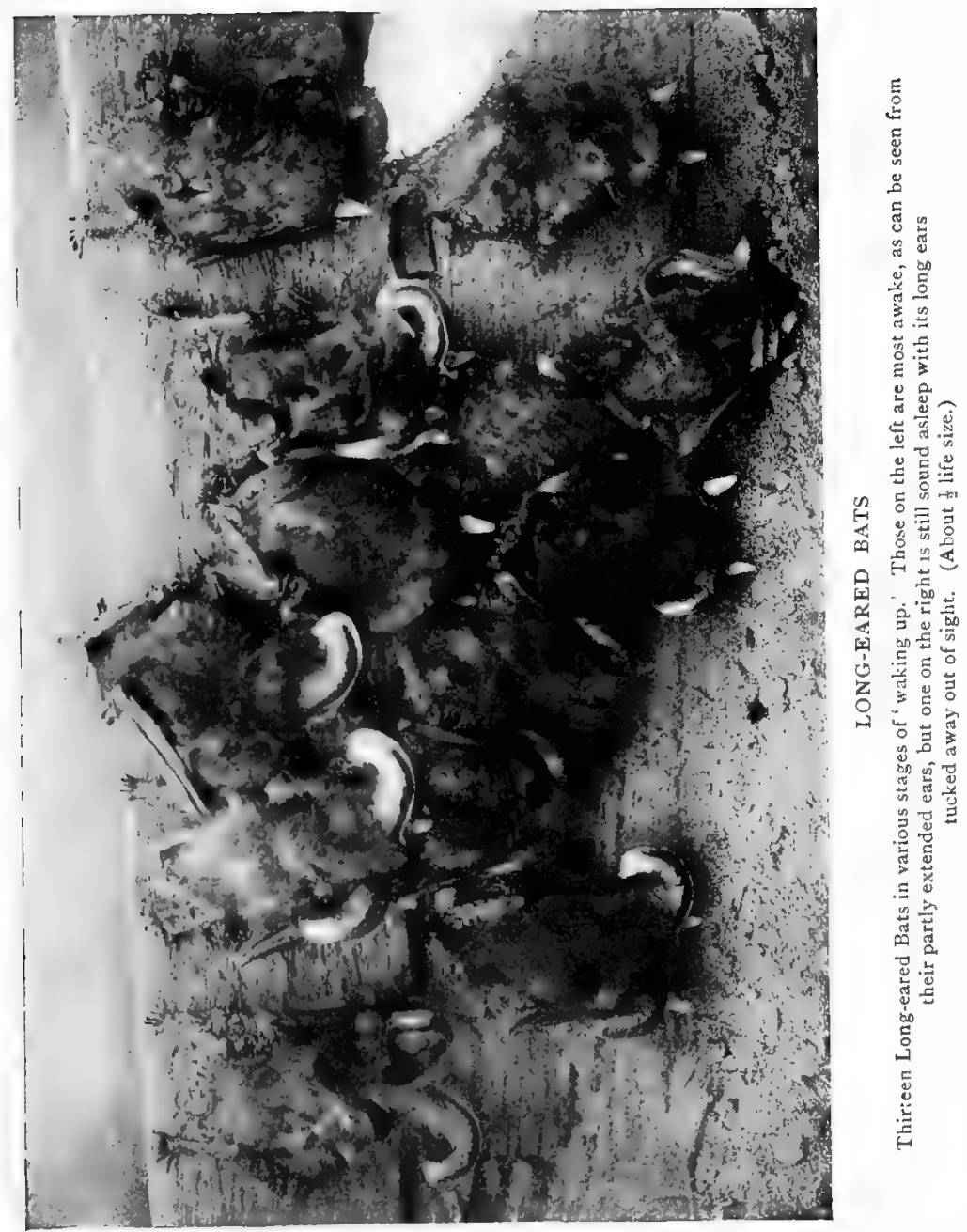



bobbed its head down and tried to pouch it, then chewed it up, rejecting the wings and legs. At this first meal it took no less than fifteen flies, in nearly all cases dropping the wings and legs. 'Jimmie,' as I called him, had quite as good, if not a better appetite than the pipistrelle, eating for his second meal over fifty flies! He grabbed them all greedily, spreading out his wings and trying to pouch them in his tail pouch, often over-balancing in his effort to do that which he was in the habit of doing. He would grab the fly and drop it into his pouch, and therein get a fresh and better hold of it, after which it was eaten in the ordinary manner. He would run towards me for flies when they were held an inch or two away from him, but I could not be sure whether he saw or smelt them. He got quite indifferent to being touched, and would go on happily munching while I stroked him. After keeping Jimmie for several days I took him to a loft and let him go, as I hoped he would there find a safe hiding-place. I was afraid to keep him any longer, for flies were growing scarce, and, with the pipistrelle's fate as a warning, I knew I could not give him all he would want. All the people who have tried 


\section{WILD CREATURES OF GARDEN AND HEDGEROW}

to keep bats, so as to find out more about their ways and habits, have experienced the same difficulty in keeping them alive and well. Whether it is a question of not getting the right food, want of exercise, or what, I cannot say, but it is impossible to get a bat to live for long in a cage. So if you should come across a bat, do not shut up the poor little creature, but after finding out all you can about it let it go again. There is plenty to learn about bats, for really, compared with other animals, we know so little of their habits.

Take the matter of their young : how many people have seen a baby bat, or can tell you what one is like? Most of the British bats have only a single baby at a time, though abroad it is the rule rather than the exception for two little ones to be born. They are naked pink mites at first, but have wonderful powers of clinging, clutching to their mother's fur, and never letting go until some weeks old. The mother suckles her baby just like any other animal, for bats are mammals, which means they suckle their young. Wherever the old bat goes she carries her little one with her, and is quite at a loss what to do if anything happens and she parts with it. Clinging to her 


\section{BATS}

side, safe under her wing, it is snug and warm while its coat comes and it grows and develops. As young bats are generally born in the middle of the summer, they are full grown and able to look after themselves before the time comes for the winter sleep.

Some bats separate for the winter, like the long-eared bats I have mentioned, but others congregate in large numbers. This is especially the case with those kinds that like caves, such as the horse-shoe bats, of which more by and by. There are some caves which have been used by bats for countless years, and their droppings have accumulated until they are a thick mass on the floor. If you look at a heap such as this, you will be able to form an idea of what bats feed upon, for it is made up of the undigested hard parts of insects, chewed wings, wing cases of small beetles, insects' legs, all broken up and difficult to distinguish, but unmistakably belonging to insects. It is the search for good roosting-places that sometimes makes bats come into the house.

The long-eared bat is the one which so often gets into the rooms in an evening, for when hunting round the house for insects it is apt to dart in at any open window, only to cause 
excitement that is too foolish considering what a harmless little thing it really is. However frightened the people are, the poor bat is more terrified, as it is chased here and there as they try to drive it out. It is wonderful how these bats can dodge, turn, and twist. It is almost impossible to catch one with a butterfly net, and I have often tried for twenty minutes or more before getting it. Whatever the wing power of the long-eared bat, it is nothing to that of the great bat or noctule. It flies more like a swallow than a bat. I never see one of these bats darting across the sky without thinking of the summer evening when I had been fishing on some large ponds that lay in a wooded valley. Just as the light began to fade, numbers of swifts came hawking for insects over the pools, and it was extraordinary how loud the rushing of their wings sounded on the still air. Their flying was a marvel to watch. At the 'edge of night' noctules appeared among them, swooping and turning like the swifts, but flying with the highest-this was about 10.30 P.M. (summer time) - and as it grew a little darker the birds vanished and only bats were left. There were hundreds of them dashing to and fro 20 


\section{BATS}

in splendid style. As the shadows deepened over the pool other bats came out. A number of swift-flying bats skimmed low along the surface of the water, which they frequently dipped into like swallows on a summer afternoon. ${ }^{1}$ Near the shore little flitter-mice fluttered up and down, and shapes that appeared and disappeared among the trees that overhung the water were certainly long-eared bats. But the flight did not last long; by 10.55 the noctules were getting less, and in a little while had all gone. The little pipistrelles were left last, for these small bats stay longer on the wing than the big ones, and sometimes even stay out all night when other bats are resting to be ready for the morning's hunting. It was a wonderful sight to see all these bats flying about together; and the pool in the twilight, backed with the shadowy purple woods, reflecting the crimson sunset dyed sky, with the hosts of first swifts and then bats turning and wheeling against it, was a thing to remember.

I have already said that there are no less than twelve different kinds of bats in this country. Perhaps the strangest looking are

1 Almost certainly Daubenton's Bat, a water-loving species. 
the two horse-shoe bats, known as the greater and the lesser. They both have 'nose-leafs,' which make them look as if they carried tiny horse-shoes in front of their faces. It is to this quaint decoration that they owe their name. They are chiefly found in the south of England and are not very common. The whiskered bat is a small grey-coloured bat, about the same size as the pipistrelle. It is fairly common, and may be seen flying with it in almost any garden. But any evening that you go out just when the light is fading you may be certain of seeing the pipistrelle and the long-eared bat hawking round the house and up and down the garden, for there are few buildings where these two common bats cannot manage to find a snug hiding-place. Of the other six bats there is not much to say, for they are uncommon and not likely to be met with, but this is not such a great loss, for they are not a bit more interesting than those which we can see and watch any warm quiet evening.

(The twelve species of British bats are as follows: Rhinolophus ferrum-equinum, and $\boldsymbol{R}$. hipposideros, the Greater and Lesser Horse-shoe Bats; Myotis daubentonii, M. mystacinus, $M$. nattereri, $M$. bechsteinii are respectively Daubenton's Bat, usually found near 22 


\section{BATS}

water, the Whiskered Bat, a not uncommon species, Natterer's Bat, which is not often met with, and Bechstein's Bat, which is rare. Pipistrellus pipistrellus is the common little 'flitter-mouse'; Eptesicus serotinus, the Serotine, is very rare in England; as is Leisler's Bat, Nyctalus leisleri; but $N$. noctula, the Great Bat or Noctule, is one of our commonest species. Also plentiful is Plecotus auritus, the Longeared Bat, but the Barbastelle, Barbastella barbastellus, is very seldom found.) 


\section{CHAPTER II}

\section{THE BANK VOLE}

IF you see a little red creature running hurriedly along the bank of the garden hedge, or scurrying away through the undergrowth, you may be sure it was a bank vole, or red mouse. It has been called the 'bank' vole because it likes woods, hedgerows, and sheltered places, and does not care for the open fields like its relation the little short-tailed field vole. Out in the open there are so many enemies to be feared; the keen-eyed kestrel hovering high overhead keeps watch by day for all the wee creatures that move beneath him, and by night there are the different owls, hunting silently like winged cats, and which like nothing better than a poor little mouse. The other name, red mouse, refers to its colour, which is a very pretty bright red-brown. Before going further I had better explain that the words "vole" and 'mouse' mean the same thing, but in books on animals it is usual to write of the 24 
short-tailed, long-furred, short-eared mice, as voles, and of the slim, long-tailed, thin-coated, big-eared, big-eyed mice, as mice. There are several kinds of each in England, but of the voles the bank vole is far the prettiest. It is really a sweet little creature, so bright and smart in its red coat, white under-parts, with its little prick ears and beady bright eyes. It has little wee paws just like tiny hands, with which it is constantly washing itself. I have watched a bank vole sit up on its hind legs, lick its paws, run them over its head, lick them again, rub its head again, and repeat this again and again, just like a cat washing her face, until at last it was satisfied that even the backs of its ears were thoroughly cleaned. Then it twisted round and began to lick its back, parting the fur with its paws so as to get down to the very roots. Bit by bit it was all gone over, after which it turned its attention to its stomach, licking carefully with its tiny pink tongue the greyish-white fur, and parting it too so as to get at the under-part, when it showed the greyish roots, for the hair, though white at the top, is grey underneath. Having finished its 'waistcoat,' it worked on lower down, and finally picked up its tail and 
cleaned it too from root to tip. Finished at last, it sat up, looked round, listened for a moment, took alarm at some slight sound, and was gone in less time than it takes to tell. When a mouse is frightened it does one of two things: it either dashes for home and shelter, trying to reach cover before its foe is upon it, or it 'freezes' where it is, keeping quite still until the danger is past, hoping that it will not be seen, and trusting to the colour of its coat to hide it. The red-brown fur matches the soil, dead leaves, and withered grass wonderfully well, so that the vole is very difficult to see while it keeps still. It is lost, has become merely a bit earth, a broken clod, and the likeness is helped by its white under-parts, which do away with the dark shadow that its body would otherwise cast. Even the keeneyed kestrel will be deceived, but woe to the mouse if it moves too soon! Out of the sky will fall the hawk, dropping like a stone on its prey, and that vole will be gone from its home for ever.

That it is danger from above which all mice fear most was well shown when I kept three bank voles in a large glass-sided cage. They did not take any notice of things moving beside 
them, but the slightest thing overhead sent them dashing for cover or made them crouch like stones where they were. The cage was arranged to be as much like part of a bank as possible. There was soil, stones, and turfs in it, and leaves and dry grass for bedding. There were three voles, two small and one big one. The latter, a male, did not seem to think it necessary to be polite to the ladies, for when the three were put into their new home they at once began to fight. It was such a scrimmage that I thought they would hurt one another, but after watching them for a bit could see there was a good deal of bluff about the fighting. They would stand opposite each other squeaking furiously, and from the noise it sounded as if they meant murder, but they never came to actual grips-the worst that happened was for one to push at the other with its fore paws. Once the big mouse knocked one of the little ones over (as I have said, he was quite a Hun; he had no manners at all where the ladies were concerned), but she made no attempt to get up-she simply lay where she was, and struck out with both fore and hind feet, ' combing the hair' of the bully with great effect. 
Even after they had settled down in their new home their manners did not improve: they quarrelled over everything, and sometimes over nothing. Food was a constant source of trouble. One day I dropped a bit of bread into the cage, which was soon found by a small mouse. She picked it up, and holding it in her paws began to eat it, but had hardly had time to gnaw more than a mouthful or two when out came a second vole. She did not wait to see what number two would do, but reared on her hind legs and squeaked; so did number two, though it had not seen the 'find ' the first was so anxious to keep. Like two boxers, they came nearer to each other. Round and round they went, prodding now and again at one another. They were far too intent on each other to see that the big mouse had come out; he looked at them, sniffed the bread, picked it up, and scuttled off to the nest, where no doubt he ate it quietly while the others went on with their fight. They squeaked at one another, and if it was not swear words it sounded like it; they pushed and shoved each other about, they fought up and down the cage, until at last one turned tail and ran. After her raced the other, bringing her to bay in the corner of 28 


\section{THE BANK VOLE}

the cage, but here she turned on number two with such effect that it in its turn ran away. Suddenly it dawned upon them that the bread had disappeared, that which they were fighting for had gone! They stood for the moment looking very foolish little mice, then they disappeared into the nest. In a second or two the squeaking began again; they had found the thief and what was left of the bread! Out of the nest he rushed with a bit of the bread still in his mouth. Round the cage he ran with his spoils, followed by the two females, who had forgotten their quarrels and made friends in their anxiety to revenge themselves on the thief. Up and down they raced, the big vole turning every now and then to squeak at those which chased him, but his mouth being full he could only make funny little muffled sounds. The end of it all was that the bread fell to pieces, and each grabbed a bit and ate it up.

For many of their fights and quarrels there seemed no reason at all, neither why they should start or stop, so that I thought it was just idleness and want of something better to do ; in fact, I believe, they enjoyed it very much. There were some more mice in another cage next door to them, which also fell out 


\section{WILD CREATURES OF GARDEN AND HEDGEROW}

sometimes. When the bank voles heard a squeak they would rush out of their nest, glance here and there, eager for the fray, and evidently thinking that strangers had invaded their quarters. After watching one of them sit up with pricked ears and listen to the quarrelling next door, one could not doubt that, like the Irishman, they loved a shindy. Once being short of a cage for a newly captured bank vole, I put it in with the three, but they went for it with such fury, and all three at once, that I had to take it out again for fear they should kill it.

Despite their bad temper the three bank voles shared one bed. They scratched a hole under a sod of grass and carried into it leaves, dry grass, and fibre, which they shredded up until it was very fine and made a most warm and comfortable lining. It was most interesting to watch them gathering bedding material. A mouse would come out, look about it, sniff the air, and then begin to gather up any rubbish that might be lying around, until it had a bundle. The way the sorting into a bunch of equal lengths was done was quite funny, for the vole held the bundle against its stomach in exactly the same manner as a man 
sorting straw for thatching holds his straw. If you have seen this done you will know exactly how the mouse went to work. As soon as a mouthful had been collected, the vole took the bundle in its jaws and ran home with it; but if it found any difficulty in getting the stuff down the entrance hole, it at once turned round and dragged its load in backwards, when it generally went quite easily.

All food not wanted for eating at once was also taken into the nest or buried. It was really sad to see the trouble a vole would take to hide away any particularly nice piece of food, only to have it stolen a few moments later. One day the smallest of the three found a bit of walnut that had not been noticed by the other two. Appearing highly delighted with her find, she picked it up but did not seem to know quite what to do with it. She looked towards the nest, listening and hesitating, but the others were sleeping peacefully inside. This being so, the usual store corner by the sleeping-place was no use, so, after sitting up and thinking, she carried the piece of nut to the far end of the cage-farthest, that is, from her friends-dropped it, and began to scratch in the loose soil. I think she wanted to dig a hole, 
but the soil was so loose that it fell in as she worked, so that she was soon quite buried, though all the time flinging out a little shower of sand with her rapidly moving hind feet. The nut fell in with tumbling soil, and was covered by it. A minute later the vole backed out, covered with dust and earth, but a good shake threw off the bits, leaving her as smart as ever. She looked round for her treasure, which had gone, but she seemed to understand what had become of it, probably smelling where it was buried, for after sniffing at the spot she ran away, caught hold with her teeth of a lettuce leaf, and pulled it to the place where the nut was hidden. Then she dragged another up, also to cover the spot, then another, and yet another, until five leaves were piled one above the other. Even then she was not satisfied. She stood and looked at her work for a second, then turned her back on it and began to scratch up the sandy soil and throw it over the heap. Her fore legs went up and down, and the earth flew out between her hind ones in a pattering stream, then as suddenly as she had begun she stopped, turned round, and looked at her work. No, the result was not perfect yet ! She went close to the pile and 


\section{THE BANK VOLE}

began to push and poke the soil into place with her nose, just as a dog does when it is burying a bone. Then the little bank vole stopped, looking towards the nest and listening with pricked ears, but the others were still quiet, so off she ran, picked up an empty nutshell, and brought it to the heap. Next she found the skin of a sweet chestnut, then two or three other odds and ends, and so she worked on, busily adding to the pile which was to keep her precious piece of nut safe from the other voles; but at last there came a stir and rustle from the sleeping-place, at which she darted away from the heap, scurrying to the opposite side of the cage, where she sat up and washed her face in the most innocent way. At lightning speed her paws passed over her head, and down her body, after which, as the other mice came out, she strolled quietly to the nest hole, seeming as if she said, "There is nothing to interest you two out here!'

Alas! no sooner had the little vole gone home to rest, than the biggest mouse began to sniff about the cage, his keen nose reading the tale of what had been done. He smelt the heap over carefully, began to scratch at its side, and in less time than it takes to tell had 
made a hole under the pile, and was backing out again with the walnut in his mouth. There and then he sat up, and while the owner slept happily in the nest he took it in his paws and nibbled away at it until it was all gone. All her labour had been thrown away!

I do not think these mice really minded very much when their hoards were taken. They had more food than they could eat and their memories were not very good, so the things they had buried were soon forgotten, and in the case of corn, unless dug up by chance, was left until it sprouted. Of course in a wild state hunger might prompt their memories, for in the winter the wee creatures of the countryside are often hard pressed for anything to eat. In the autumn most of the mice lay by stores in their tunnels to provide against the bad times of winter. No mouse works harder at this than the bank vole; anything it does not want at the moment is carried homeberries, nuts, and grain are hidden in the holes. How hard it will work was shown when I dropped a handful of barley into the cage where my voles lived. One of them soon came out, sniffed at the grain, picked up a mouthful and carried it off. In fifteen minutes 


\section{THE BANK VOLE}

it took away seventy-five grains of corn, making eighteen journeys in all. Four pieces of barley were the most it could manage comfortably in its mouth at one time, but it would try and carry more, when they fell out at the corners of its mouth, and it had to pick them up and push them in again, which it would do several times over. The first two loads it buried in the soil, scratching holes, dropping the grain in, and then scraping the earth back again, but the rest were taken down one of the tunnels, and judging by the little time it wasted the vole must simply have dropped the corn and not bothered to cover it up. Its way of picking up the grain was to take each piece up in its teeth, and then push it well into its mouth with its paws. The biggest mouthful I saw it push in was seven pieces of corn, when its cheeks simply bulged! Any grains that were dropped when loading up were carefully picked up again and not left lying about. Another vole working in an extra hurry managed to carry off twenty-one loads in ten minutes, taking ninety-one grains home in the time; but this was beaten when a mouse took home twenty-three loads without a pause between them, and then, after resting for a moment, 
went on again, making altogether forty-two journeys in which it hid one hundred and sixtytwo grains of barley!

This gives some idea of what the red bank vole can do, for it is really a most mischievous little creature, eating and spoiling great quantities of stuff in our fields and gardens. It is not at all particular what it eats; it likes all kinds of grain, including wheat, barley, oats, peas and beans, fruit, such as apples, pears, strawberries, gooseberries, and plums, nuts of every sort, including walnuts and sweet chestnuts, acorns, berries like those of the wild rose and hawthorn, and even green food, such as lettuce leaves, the young blades of barley, wheat, and oats, and dandelion, of which it is very fond. To get the hips and haws in the autumn it will climb up the bushes, running out to the very tips of the branches to get the berries, for it is quite at home up aloft and has no fear of falling. Very often it carries the fruit to some old bird's nest to eat, which is the reason that in the autumn one so often sees disused nests full of scarlet bits. These nests serve as the dining tables for all the different mice that like hips and haws. Sometimes in the spring, when the bank vole climbs into 36 

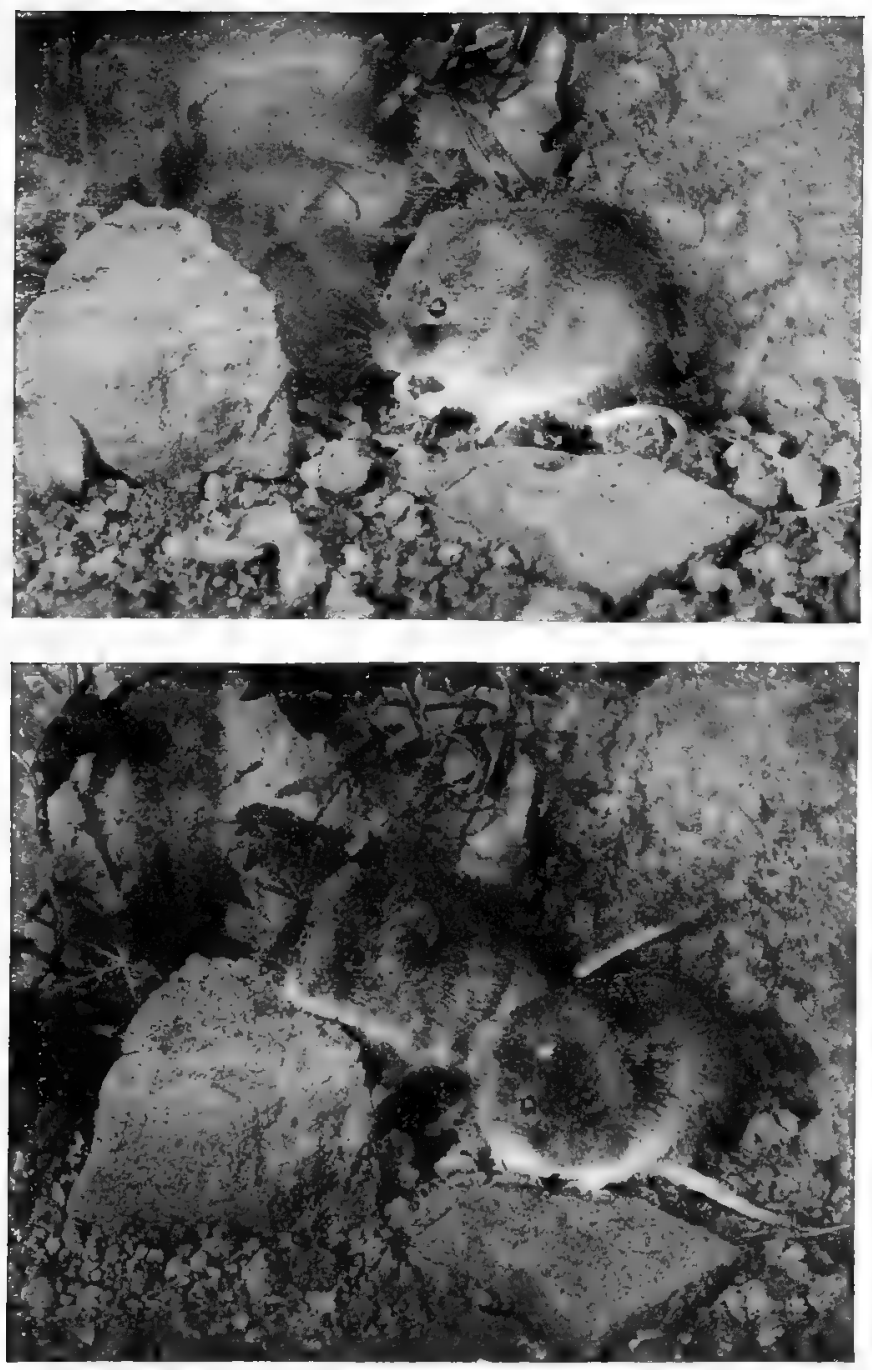

BANK VOLES

No, x. 'Stolen Goods' No, 2. 'On the Alert

(about th life size) 



\section{THE BANK VOLE}

the bushes in search of any odds and ends of berries that may have been missed during the winter, it will come across a new bird's nest, when it will make short work either of eggs or young ones, for this pretty little vole does not, when it gets the chance, mind eating flesh-it will even eat its own friends! In short, it is not above being a cannibal! Really there is very little the bank vole will not eat, and when it becomes plentiful it is a serious nuisance. Once in a way, generally after a mild winter and a warm dry spring, all the different kinds of mice begin to increase in numbers-bank voles, field voles, and long-tailed mice get more and more numerous. Family after family of little mice are brought up and started out into the world, and in a very short time are bringing up families of their own. The owls, hawks, foxes, and cats catch and eat mice until they are sick of them, and still the mice go on increasing. They eat everything, even the bark off young trees, and in gardens and allotments clear all things before them. This is what is called a 'vole plague,' and it is a very serious matter. Generally it is brought to an end by disease breaking out among the swarms; they die by hundreds, and for a time 
the different mice will be even scarcer than before they began to increase.

In ordinary times the bank vole is not a very common mouse, though found in most parts of Great Britain, and particularly fond of gardens, for there it can find many good things which are to its liking. It is easy to trap, being an inquisitive little thing, and ready to go into anything for cheese. It is often caught in the daytime, for it has not that horror of the daylight shared by so many of its relations. Most mice are strictly creatures of the dark, but the bank vole also runs about in the daytime. It generally makes its nest under some old stump or stone on a warm dry bank, and has a system of roads or tunnels running from it through all the surrounding plants. If you look carefully into a hedgerow you will see that down among the rubbish, the dead leaves, grass, and plant stems, twisting between the sticks and stones, are the high roads of the little people of the fences. Wellused tracks run here and there beaten and padded by many tiny feet, and these are the highways of the bank voles, the long-tailed mice, and the shrews when they go out on their hunting expeditions. Through these runs 


\section{THE BANK VOLE}

sometimes comes the weasel, that terror of all the small creatures, for he is the fiercest and most bloodthirsty of hunters. No bigger in girth than the mice he hunts, he can follow them through all the turns and twists of their runs, through all the windings and secret ways of their burrows. The mouse whose trail he fastens upon is as good as lost; no matter how it may turn and double, how often its line is crossed and confused by other trails, the skilled hunter will unravel it all, and follow on to the end, until there is a stifled squeak in some dark corner, and that mouse is gone for ever.

In fact, the red bank vole lives a life of constant danger; death may come at any moment, but I do not think it therefore follows that the little creature is unhappy. Its frights do not last long; crouching close to the ground one moment, frozen by a shadow flitting overhead, next second it will be squeaking at its friend for taking the berry that it wanted itself. What matter if the weasel passes through the burrow, sending the family scampering headlong in all directions; they soon come back again, and, if there is one less at the feeding-place, it is no good bothering 


\section{WILD CREATURES OF GARDEN AND HEDGEROW}

and worrying while good nuts are to be had. So it goes on : the fox, the cat, the weasel, the owls, and the hawks, all take their toll, keeping down the numbers and saving us from a vole plague, from little red mice running all over our gardens and eating them bare of everything.

With the spring, however few the voles have become, their numbers begin to go up again. With the warmer days of March and April there come a stir and disturbance in the mice world; there is much squeaking and fighting, mother voles seek holes to themselves, where they collect fine grass and leaves, and, shredding these up, make a soft warm bed. This is the nursery for the tiny naked pink babies, which may number from two or three up to six or seven. About four is the most usual number. They grow very quickly and are soon covered with dark down-like fur; then their eyes open (they are blind to begin with), and by fourteen days old are able to run about and feed themselves. While the young are small and helpless their mother is most devoted to them, and a caged bank vole has been known to attack a hand put near her nest. As soon as the first family is able to look after itself the mother begins to get ready another nest. Very likely this 40 


\section{THE BANK VOLE}

will be on, not under the ground. Beneath a heap of rubbish, under the shelter of a piece of wood, or a big stone, this next nursery may be found. In it another family will be brought up and in their turn sent out to earn their own living and learn the hard ways of the world. The young ones at this age are particularly sweet little things, clad in brown fur, but not quite of so bright a tint as that of the old ones. Once when walking beside a hedge I saw a small bank vole sitting on the flower head of a large 'cow-parsley' plant. Its perch was at least three feet from the ground, but there it sat quite happily, holding firmly with its hind feet, and busy nibbling at a piece of the flower which it held in its fore paws. It looked such a wee baby to be out by itself, and if it had not been so young and foolish it certainly would not have sat there in broad daylight for any passing hawk to see. The young voles grow very quickly, and before the end of the summer will probably have families of their own, but they may go on growing even after this, as, unlike people, they increase in size until quite late in life. A full-grown bank vole is about four inches long (head and body), and has a tail another two inches in length. It has a very 
neat slim body, indeed one might say that it has a small waist, and a head that looks very large in comparison with the rest of it, and which when compared with its small hindquarters gives it a top-heavy look. In these points it is very different from the round furry ball-like field vole with its rough shaggy coat. The bank vole's coat is always neat and smooth, always looks well groomed, and so it ought to considering how often it washes and licks it. Now the field vole is sometimes rather stupid looking, but never the bank vole, which with its pricked ears and keen sharp eyes has almost a foxy expression, especially when listening with one fore foot raised for slight sounds. The hearing of these mice is wonderfully keen; the faintest sounds will often send them scurrying to the nearest shelter, and I think they must be able to hear things too faint for our ears.

To go back to the question of young ones, family succeeds family throughout the summer, and, if the autumn is an open one, on until nearly Christmas. Cold weather brings the nursery business to an end; the voles then go into winter quarters, being far less lively when snow is on the ground than at other times, 


\section{THE BANK VOLE}

though they do not pass into a long sleep (or hibernate) like the dormouse. They may. stay in their burrows more than usual, curling themselves up in tight balls to keep out the cold, but whatever the weather they still go out into it, and if you find a strange little track in the snow like a rat's, only very much smaller, but without any mark of a tail dragging behind, that was made by the bank vole, which always carries its short tail cocked up in the air, whereas the long-tailed mice often drop their very long tails on the snow, and thus mark their trails quite unmistakably. As a matter of fact the bank vole prefers to tunnel under the snow rather than run over its surface. A brown mouse on white is too easily seen by its enemies, but under the covering of snow it can drive its holes anywhere in safety.

Really a mouse is never safe, there is always something to be feared, some creature or other ready to pounce on it; and, however pretty and charming a creature the bank vole may be, we must be very thankful that it is so, or our gardens, allotments, and fields would be overrun with them. It is because they kill the tiresome mice that people should not shoot, or 


\section{WILD CREATURES OF GARDEN AND HEDGEROW}

trap, or allow the eggs to be taken, of hawks and owls. Owls, and the kestrel in particular, live almost entirely on mice and young rats, and when we kill a barn owl (the barn owl is the white owl which flies about so silently over the fields) we are allowing hundreds of mice to live and thrive and eat our things.

(Note.-The bank voles, Evotomys, are widely distributed throughout the northern hemispheres, $\boldsymbol{E}$. glareolus being the commonest European representive of the genus. The British bank voles are as follows:- $\boldsymbol{E}$. glareolus britannicus, differing in several particulars from the Continental type, and which is widely distributed throughout England, Scotland, and Wales, but does not extend to Ireland. An allied but distinct species has been found on Skomer Island, off the coast of Wales, and has been named $\boldsymbol{E}$. skomerensis. Then there is $\boldsymbol{E}$. alstoni, lately discovered on the Island of Mull, and $\boldsymbol{E}$. erica, peculiar to the Island of Raasay.) 


\section{CHAPTER III}

\section{TWO COMMON BIRDS}

No garden, however small, is without its blackbirds and thrushes. Wherever we go we meet the blackbird and the thrush. Everybody knows them, the former in his smart black uniform with contrasting orange bill, and the latter in more sober brown set off by his daintily spotted waistcoat. They raid the fruit in our gardens, allotments, and orchards, the former being by far the worst thief of the two; they make their nests in the shrubs at our very doors, bringing up their families and displaying their housekeeping ways under our eyes; and they pour forth the joy of life in glorious song from the tree-tops by our windows. Yet these two birds are not, like the house-sparrow, the rat, and the house-mouse, pests, that live entirely on what they can steal from us, following mankind as parasites all over the world, and hardly able to exist where there are neither people nor houses, but are really 
wild creatures, living (despite a little fruiteating in the autumn) chiefly on grubs and insects. They are not dependent on men for a living. They are found far from any dwelling, in the wild valleys among the hills and in lonely glens where people seldom go. Wherever there are trees and bushes to shelter them will be found blackbirds and thrushes, whether that shelter is the hedgerow fencing in a little garden, or the untrimmed brakes of a wild woodland. Indeed, they are truly free creatures, and bring the wild life of the countryside close to our bricks and mortar, so that we can watch them any day and every day busy at work.

Perhaps the busiest time for them in the twenty-four hours is just after daybreak, when, flying down hungry from roost, food has to be hunted for and found before breakfast can be had. Now the old proverb says that 'the early bird gets the worm,' which is absolutely true, as every blackbird and thrush knows to its cost. During the night the worms come up to the surface of the ground, and, stretching out of their burrows until only the tips of their tails remain in the holes, they feel around for fallen leaves, bits of grass, and 


\section{TWO COMMON BIRDS}

other odds and ends to draw down their burrows, for they feed on decaying vegetable fibres. As they keep the end of the body in their tunnels they can retreat in an instant when they feel the slightest shaking of the ground. Though without eyes or ears they are most sensitive to tremors, so know just as well as creatures that can see and hear when there is anything coming near, even the light footsteps of a bird hopping over the grass being enough to make them draw hurriedly back into their holes. In any case they go home soon after dawn, retreating down their holes as the sun creeps up over the horizon, warming the air and drying the dew-soaked grass. This being so, the blackbirds and thrushes which want worms for breakfast must be down at break of day and, hopping cautiously over the sodden lawns, pick up the worms before they have the time to slip away. It is always an amusing sight to see a thrush grab at a worm which is anchored by the other end to its burrow. The bird pulls with might and main, while the grub does its best to wriggle away down its hole. Suddenly the bird lurches backwards, nearly sitting down on its tail, for the worm has either given way or parted in 
the middle. Its captor gives it a good shake, like a dog worrying a rat, beats and shakes it until it is quiet, then swallows it with a gulp, and hops gently on to look for another worm. The number of earth-worms that thrushes alone destroy must be very large, for they feed their young ones entirely upon them. I have watched the old birds taking home food to the nest, and have never seen the nestlings given anything but earth-worms. Every ten minutes, on an average, one of the parents would come hopping through the twigs and up to the edge of the nest with a beak as full as it would hold. Some seconds before the old thrush jumped on to the side of the nest the babies knew food was near, their heads on long trembling necks shot up into the air, and five orange gapes were open wide for the good things to come. Carefully and impartially the mother, or father, as the case might be, distributed the load, first down this anxious throat, then into the next wavering beak, until all sank back happy and contented into the nest. Though the food was disposed of the old bird would wait a moment or two, for the nest had to be kept clean, and nothing must be left to soil it. While the little ones are very 
small the old thrushes managed this by swallowing their droppings, but as the nestlings get older they simply carry them off and let them fall at a distance. The excreta of all young birds that are brought up in nests is coated for the purpose with a slimy covering which will not stick to anything, so the old birds can clean out the nursery without any fear of getting in a mess.

I have said that young thrushes and young blackbirds are fed entirely on earth-worms, but these are not the great fat worms that the birds get on the lawns in the early morning, but smaller red ones, which I believe they find by hunting about among decaying leaves under the trees-at any rate I have never seen anything else brought, and I have watched thrushes at the nest for hours at a time. What hungry youngsters the babies are; it does not matter how often they are fed, they are always ready for more. Even if they have been fed only a second before, their heads will pop up and their beaks be open wide on feeling the slightest shake of the nest. They keep their unfortunate parents hard at work from daybreak to dusk, only allowing them to slacken for a little while at mid-day. Or maybe what really 
happens is that the old birds go on strike! At any rate they do not go backwards and forwards quite so often just then. At first, while the little ones are very small, the cock does most of the work, their mother staying to cover the naked mites from both sun and rain, for they are nearly as much distressed by one as the other. It is not only for shelter from enemies that birds choose thick bushes in which to build their nests, but also for the sake of shade.

How sensitive nestlings are to the slightest shake of the surrounding branches may be tested by gently moving one of the boughs, when the four or five heads will shoot up into the air, and beg with open beaks for food. In a second or two, if nothing happens, they sink back again, only to shoot up again like 'jack-in-the-boxes' at the least trembling of a twig. When they get older, when their eyes are open and their feathers are beginning to grow, the young birds are not so easily taken in; they no longer open their beaks in expectant innocence when a finger is held near them, but crouch down in the nest. Fear has come to them, the fear of all that is strange, and particularly of man, the strangest 50 
thing of all! What a change there is the moment one is out of sight; they no longer crouch down with feathers drawn as tight as possible, but sit up, look this way and that, and try and preen their baby plumage. Long before they leave the nest they begin to arrange their rapidly growing feathers, running their beaks down the shafts of the feathers and thus keeping them in good order. In less than three weeks from the time of hatching young thrushes and blackbirds are ready to leave the nest; they are then full fledged, except that as yet their tails are short and stumpy. Of course a long tail would be dreadfully in the way when four or five big young birds are packed into a shallow nest but three or four inches across. If their tail feathers grew before they left the nest they would certainly get broken and spoilt, but Nature manages better than that; it is so arranged that their tails remain short until the youngsters go out into the world, and then grow rapidly, so that by the time they are strong on the wing they have a long tail to steer with. Tails are the rudders with which birds steer, and also serve as brakes, helping a bird to slow down when it wants to alight suddenly. 
When they first tumble out of their nest young blackbirds and thrushes fly but feebly; they cannot steer well, they can only flap along into the bushes, and there hop from branch to branch. What a change it is-one moment they are warm and snug, a happy family wedged tightly into their almost overflowing nest, looking out on to the great world of greenery with its unknown joys and dangers; next minute they have gone over the edge, and are fairly launched into the new life. Generally something makes them go. They sit there hesitating, fearful of the great adventure, feeling life strong within them, and the impulse we call 'instinct' bidding them set forth, while the old birds call and urge them to come, but if nothing unexpected happens they may put it off for hours. They settle down into the nest once more, preen their feathers, doze, swallow greedily the food brought by their untiring parents, until startled into action by something unexpected. It may be a passing dog, cat, or person, but the fright sends them fluttering with frantic squeaks into the surrounding bushes. One goes one way, one another, each 'freezing' into a motionless object wherever it alights, while the old birds, 


\section{TWO COMMON BIRDS}

brought home by the outcry, try with piercing shrieks to draw off the intruder. As long as they think they are invisible the young birds remain quite still, in the case of thrushes with their feathers drawn tight and their beaks pointing skywards, for in this attitude the spots on their breasts and throats appear like lines, and these lines make them very hard to see among twigs, grass, and leaves. Very often this saves them; they are overlooked by the foe, and the enemy having gone on peace will reign once more. The young ones are now scattered, probably never to meet again, over an area perhaps twenty yards square-how are the old birds going to manage, for the little ones cannot feed themselves yet? Well, that short flight has worked great changes in the young birds. While they were in the nest they sat quiet and never made a sound except when the parents were coming to them with food. Now they keep up a plaintive and monotonous squeaking. Steadily and persistently they squeak, full-fed or hungry makes no difference, for they still call. It is really their way of saying, "Here we are!' and by this means they let the old birds know where to find them. Without trouble or loss of time the old thrushes or 
blackbirds, as the case may be, go straight into the heart of the thickest bushes and feed the waiting babies. For a day or two this continues, the hard-worked parents carrying worms to the youngsters lurking under the shrubs and in dark corners, hiding from the dangers which they are not yet strong enough to fly away from. Great are the losses in thrush and blackbird families at this time. It is just the moment when all the countryside is a nursery; hawks have their eyesses to feed, owls their owlets, foxes their cubs, stoats and weasels their young ones, and all are glad to carry off young birds to their families. Danger is on all sides, and the weakly nestling which, tumbling out of the nest, hesitates in the open is sure to disappear, or the too bold one, which ventures on a flight before it is really strong and swift upon the wing, will likewise vanish. Danger is on all sides, and out of the two broods that the old birds will probably bring up in the course of the season, they will be lucky if more than two survive until the following spring to nest and in their turn rear young ones. But with four or five youngsters to feed, the old birds have no time to worry if the count should be one 


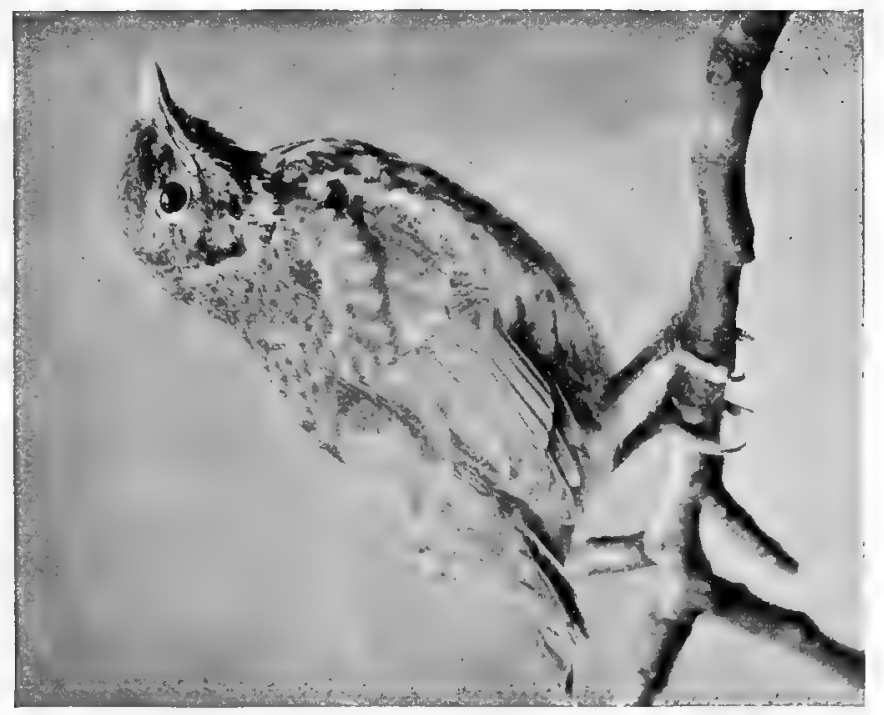

2

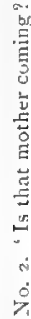

w
0
0
0
0
0
0
0
0
0

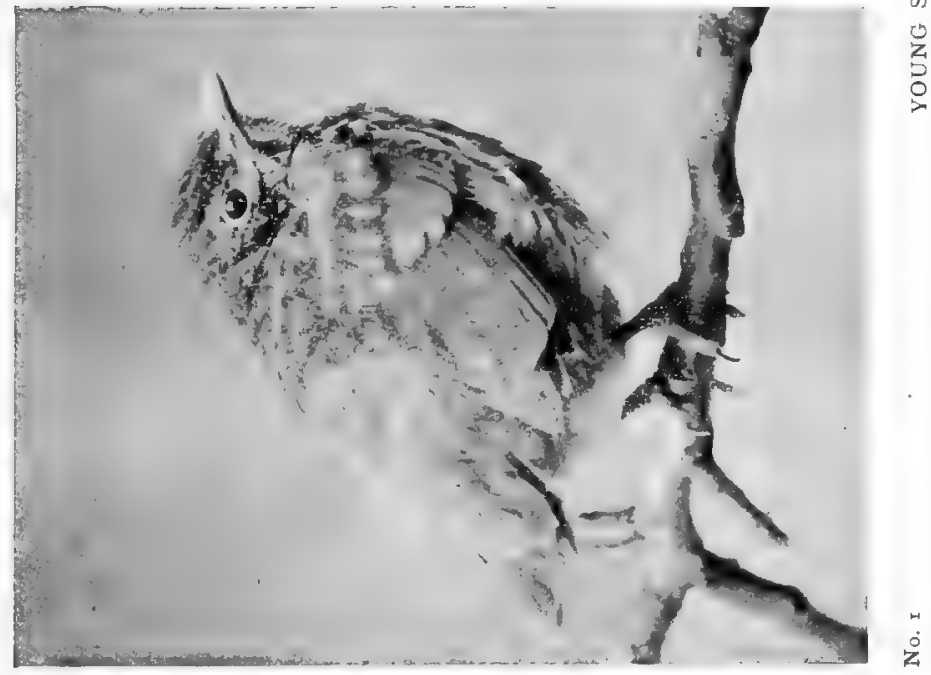





\section{TWO COMMON BIRDS}

or two short. Worms must be found, worms and yet more worms, until at last the desperate parents go on strike. The rapidly growing youngsters are now quite capable of looking after themselves. They can find and pick up food, they are quick and active; indeed they are full grown, but they do not like having to fend for themselves. They follow the old ones, squeak plaintively, and beg them to feed them. I have seen an old thrush on the lawn in the early morning looking for worms with a couple of young ones as big as herself following her about and begging piteously for food. They were quite capable of picking up worms, but their mother being there the great babies tried to get her to do it for them.

Fully fledged young thrushes are almost indistinguishable from their parents, but young blackbirds have a mottled brown dress of their own, which distinguishes them from the older birds at a glance. All the young ones moult in the autumn and then assume the full-grown plumage, so that by early winter young cock blackbirds have the glossy black feathers and orange bills that distinguished their fathers. By the time they have got their complete new outfit they are generally far from the spot 
where they were reared. We often speak of the blackbirds and thrushes as birds that stop with us all winter, as non-migratory species, but as a matter of fact they travel far and wide. Truly we do have some with us during the hardest weather, but these are not the identical birds which nested with us and reared their young ones in the garden. Those are now far away. The blackbirds and thrushes which come to feed in front of the windows on crumbs and bits thrown out for them are travellers from the north who have come down from those colder regions to our milder country. In the autumn a movement begins in the bird world which very few kinds escape. It is like the ebb and flow of the tide on the shore. In the spring the tide flows northwards, birds of all sorts and descriptions journey back from the warmer countries to the places where they were reared. Some get as far north as the Arctic Circle, and all travel many hundreds of miles over land and sea to get back to their homes. With the autumn comes the impulse to wander again; cold winds, the scarcity of insects, the inherited instinct, all set them moving. The tide begins to ebb, swallows and martins vanish, the little grey willow wrens 
and chiff-chaffs disappear from the hedgerows, and birds like starlings, thrushes, blackbirds, and other common kinds are seized with the same fever. They all flow southward, only in the case of the latter kinds we do not see the end of the flood. While our own thrushes and blackbirds are away their place is taken by others, so we always have some about, and most people never realise what has been taking place around them, what comings and goings, what flittings and arrivals, there have been in the garden. They know nothing of the weary birds that have sheltered under the bushes and in the cabbage patch, nor of the famished hunger that drives the blackbird to join the smaller birds at the feeding place where the crumbs are thrown out in front of the window. It may be asked how we know all this. For one reason, because blackbirds and thrushes are regularly seen with the flocks of other migrating birds passing the lighthouses. In foggy weather many birds lose their lives at the lighthouses, dashing against the glass and then falling into the sea, and the men on duty report both thrushes and blackbirds as numerous among the victims. Another way we know is by marking the young birds. Very light aluminium 
rings are made, marked with a name and number, which are put carefully round the legs of nestlings. They do not in any way interfere with the bird, but if at any time the wearer is killed or captured the ring identifies it. Blackbirds and thrushes marked in this way have been recovered hundreds of miles from their home, they have also been seen the following spring back in the old spot. This is perhaps one of the most wonderful things in Nature, that a small bird with no previous experience can travel hundreds of miles over land and sea, stay the winter in a strange land, and come back in the spring to not only the country in which it was born, but to the very hedgerow and bush! And it cannot be that the old ones guide them, for in many cases it has been proved that the old birds leave for the south earlier than the young ones; this is especially the case with the cuckoo, the adults leaving quite a month ahead of the birds of the year.

Those blackbirds and thrushes that choose to stay the winter here in company with their cousins, the redwings and fieldfares, that have come over from Scandinavia, often have a hard time, for during bad weather they are 


\section{TWO COMMON BIRDS}

troubled to find food. The worst winter for birds that I remember was that of 1916-17. It began early, and continued with few breaks late into the spring. The greater number of birds departed early, only a few blackbirds and one or two thrushes being left. The difficulty of finding food in the frozen and snowbound countryside made them piteously tame and friendly. The thrushes suffered most, for they do not care for berries, on which blackbirds can not only live but flourish. As a matter of fact the bushes were soon cleared of such provender. The invading flocks of redwings and fieldfares finished them and then went on south. The thrushes hunted the hedgerows carefully for hidden snails among the undergrowth, but most of these were tucked away too deep to be found. The poor birds grew weaker and weaker, they would hardly hop out of one's way, their feathers stood on end not only from cold but from starvation, and they died in hundreds. They suffered most in Cornwall, for the different kinds kept moving on south before the cold, but when they got that far were too weak to face the Channel crossing, so 'they frequented little town gardens, tripping feebly on tiny grass-plots in 
front of suburban houses, pecking among the gooseberry-bushes at the back, constantly chased by lapdogs, but constantly returning. They came to the windows for food, and died in gardens, beside roads, and in every field, and along frozen drains.' 1

The loss of bird life during that winter will never be known; only naturalists can have any idea of the countless throngs that suffered and died. Many kinds were almost exterminated, and in the district where I live birds which used to be common are now scarce. The following spring there were no thrushes singing on the tree-tops; not a nest could be found. In places where with hardly any hunting I used to find twenty or thirty nests there was not even one ! The blackbirds were represented by just one or two survivors, and that summer it was not necessary to net the fruit for there were no birds to rob it!

Though thrushes often get entangled in nets over fruit, they are not really half such thieves as blackbirds. They are chiefly grub-eaters, but blackbirds, there is no denying, are very fond of berries and fruit. Of wild berries

1 H. M. Wallis, 'Mortality among Birds during the February Frost in West Cornwall ' (British Birds, vol. x., 1916-17, p. 267).

60 


\section{TWO COMMON BIRDS}

there are few they like better than those of the mountain ash. From far and near the birds will gather to the feast, and there is a fine tree in the garden of my home which gives them an annual feast. One day it will be orange with berries, the boughs bowed down with the weight, but next day it will be stripped, the busy blackbirds having quickly relieved it of the burden.

To go back to the subject of birds in the winter time, you will notice how blackbirds and thrushes fluff out their feathers in cold weather. This is to keep themselves warm. The arrangement is on the same principle as a thermos flask. The feathers are in layers, and between them lies air. The more the feathers are fluffed out the more layers of air there are and the less the warmth of the body can escape. When the weather is warm the bird draws its feathers tighter round it, expelling the air, and so cooling itself. Feathers are really the warmest and most wonderful clothing in all Nature. They are laid one over the other like tiles, keeping the wearer dry whatever the rain, and are warm or cool wear as required. No wonder the owner takes such care of them, preening them whenever he has a moment to 
spare, and bathing as often as he can. How birds do enjoy a good wash! I have often watched blackbirds and thrushes in the shallow water at the edge of a ditch splashing the drops far and wide and soaking their feathers until they looked more like drowned rats than tidy birds. Once thoroughly wet through they fly off to some sheltered spot and there spread out wings and tail and let the sun dry their feathers. Nearly all birds love to wash themselves, and there is no doubt that the impulse to bathe is truly instinctive. They do not learn how to wash by experience or through watching other birds, but it 'comes to them' when they see water rippling. Why I say this is that $I$ have hand-reared several young birds, and will mention in particular a young song thrush which was taken from the nest while still in that innocent stage when it did not know a human hand from its mother's beak! I fed it on worms, three ounces a day being the amount it ate, and it not only lived but throve and became a beautiful bird. I know that it never saw water until the day when, being fully fledged, I put a pan of water before it. It looked at it without any interest whatever, until I made the water ripple, when Jack 


\section{TWO COMMON BIRDS}

(as the bird was called) without hesitation stepped into the dish, stooped down, ducked his head under, beat the water with his wings, and in fact went through all the motions proper to taking a bath. Indeed he took as thorough a bath as I have ever seen any fullgrown wild thrush take. When he saw the water splash and ripple he instantly understood what it was and what he must do, though in all his little life he had never seen any water save rain drops! It was a clear case of instinctive knowledge.

Of course nest building is the best known instinct among birds, young ones with no previous experience building as good, or nearly as good, nests as birds of three or four years' experience. It does seem extraordinary to think that with no one to explain to it a young bird will gather the proper and most suitable stuff with which to build, and make not only a good and serviceable nest, but one according to the peculiar pattern of its kind. You never see a thrush's nest vary from the clay-lined type that all thrushes build, nor a blackbird's that was not lined with fine grass. Every schoolboy and girl know the two nests, and know that in the clay mud-lined nest will be 



\section{TWO COMMON BIRDS}

leaves and twigs of a hedge marks and streaks break up the egg, so one does not easily see it, a plain egg catching the eye more quickly. The only bird I know that builds an open nest in bushes and hedges, and which also lays a plain egg without streaks or markings of any kind, is the hedge-sparrow, but its egg is that peculiar green-blue which is so difficult to see through green leaves. That colour and markings do help to keep eggs from being found and eaten by the many creatures which like them and hunt for them, is shown by the fact that, with very few exceptions, all those birds that make their homes in holes, or build domed nests in which their eggs cannot be seen, and in which colour and markings could not be any use to them, have white eggs. Plenty of examples will occur to any one who has done much birds'-nesting.

To go back to the subject of instinct, I must tell how $I$ found out through the young thrush which I brought up by hand, that there are some things which this bird does not know without being taught, and which it has to find out for itself. One of these things was how to break the shells of snails so as to get out the unfortunate inhabitant. But I must explain that the habit of cracking open 'house- 
snails ' 1 is peculiar to the song thrush. No other kind of bird does it, not even its cousin the blackbird. When you find a heap of broken snail shells you may be quite certain they are the work of the thrush. Each thrush has its own particular breaking stone or anvil. It may have more than one, but even if it has two or three they are its private property on which other thrushes do not poach. The anvil is usually a pebble or other hard object of just the convenient height and shape to hammer the victims upon. I have seen a thrush carry a snail a hundred yards or more to its favourite stone, though there were many others near at hand which to my eyes looked just as good; but the bird evidently preferred this one, for it was used for weeks, and the fragments of snail shells lay thick around it. Sometimes a thrush will select a pebble in the middle of the garden path as its anvil, when one can find out the results of each morning's hunt by sweeping away the bits every day. At other times the favourite stone is on a bank, or under the hedge; in fact the place does not matter as long as the anvil is all right.

1 The common banded snail, Helix nemoralis, with its many varieties, is the kind preferred. 


\section{TWO COMMON BIRDS}

Now when I offered some snails to my young thrush I quite expected him to know at once what to do with them, in the same way that all young birds know instinctively how to build a nest, but he was completely puzzled. He took no interest in them until one of the snails put out its head and began to move about, whereupon he flew down from his perch, watched it for a moment, and then pulled its waving tentacles. The poor snail hastily retreated into its shell, to the bewilderment of the thrush, who seemed to wonder what could have happened to it. He turned it over, but could make nothing of it, so tried another snail which had begun to move about, with a similar result. In disgust he flew up to his perch. Presently the two snails put their heads out again and he flew down and once more pulled their waving tentacles, with the same result as before. He could not make out what had happened to them, and it was evident that he had no idea they were good to eat nor how to get them out of their shells. Daily for a week I showed him snails, and each time he was most inquisitive about them, turning them over, pecking the shells, and trying to make out where the snails 


\section{WILD CREATURES OF GARDEN AND HEDGEROW}

vanished to. He shook one, having picked it up by the lip of its shell, just as he would have done when killing a worm, but it did not seem to occur to him to carry it to any one of the stones I had put ready for him to beat the snails on. Of course this had no effect on the snail, which only shrank back farther into its house. On the sixth day the bird seemed to lose all patience. He picked up a snail, swung it backwards and forwards and brought it down with such a thump on the ground that it flew from his beak and half across the big cage. He hopped after it, picked it up, and, jumping on one of the anvils that I had put ready for him, beat the snail several times against it, hitting it first on one side and then on the other with a swinging motion. He was not expert enough, however, to crack it, and it rolled away, after which he tried in turn all the five snails that were in the cage. He seemed very pleased with his discovery that they could be hit on a stone, and went on trying first one snail and then another, until, after fifteen minutes' hard work, one, more weak in the shell than the rest, gave way. He had cracked his first snail! Once the shell was broken it did not take him long to pound it to 68 


\section{TWO COMMON BIRDS}

bits, extract the snail and swallow it. After long trying he had found out how to deal with snails, and henceforward he practised daily (when I could find him snails), so that he was soon an expert on the anvil, opening a snail with a few blows, whereas to begin with it had taken him ages to break one. It was very evident that he learnt by experience, and that the snail-cracking habit of the thrush is not a specialised instinct, but arises from the tendency of this bird to beat on the ground and thus kill any food, like a big worm, which cannot easily be managed. My thrush would beat and hammer anything that was at all troublesome or which he did not understand; I have even seen him pick up a pill-box and hit it against the leg of the chair! A roll of paper was treated in the same way, or indeed any little thing which was strange to him.

In conclusion, I must remind those who may read this that, though blackbirds and thrushes are some of the commonest birds we have, they are not therefore any the less interesting, and that there is still much we might learn about them. When we watch them from our windows pulling worms out of the lawns, or carrying away bits of hay and grass with which to make 


\section{WILD CREATURES OF GARDEN AND HEDGEROW}

their nests, we are as much studying wild nature as if we were watching golden eagles in the Highlands ! The same great laws of Nature rule both, and we are likely to learn as much from one as the other.

(The Song Thrush of Great Britain, Turdus ph. clarkei, is regarded as a sub-species of the Continental Turdus philomelus, but our Blackbird is identical with the Turdus m. merula of the Continent.) 


\section{CHAPTER IV}

SHREWS

Shrews are those little long-nosed mice of which the cats catch and kill so many, though they never eat them. They will catch them and play with them by dozens, but from their poor little bodies they turn away in disgust. What it is that the cats dislike so much I cannot say for certain, but think it must be the curious musty smell of the shrews. If you pick up a dead shrew and examine it, parting the short velvet-like hair carefully behind its shoulders, you will see a little mark, or gland, from which oozes an oily matter, which makes this smell. Though cats, dogs, and foxes will not swallow shrews, owls and hawks will eat them as readily as any other mice.

As a matter of fact shrews are not mice at all; they are just shrewes, and nothing more. The true mice have two pair of sharp cutting teeth, or incisors, in the front of their mouth specially fitted for gnawing grain, and such 
vegetarian food, whence they are called 'Rodents'; but the shrews live on insects, their teeth are quite different, they are for biting and tearing, not for gnawing, and they are called 'Insectivores.'

There are three different kinds of shrews in this country-the common shrew, the water shrew, and the pigmy or lesser shrew. The first well deserves its name, for it is very very common indeed. Wherever there is long grass or other undergrowth, the shrews will have their paths and tunnels, along which they race at a surprising pace at all hours of the day and night, for, unlike so many wild creatures, they have no preference for the dark. If there is a wild or rubbishy corner in your garden, where the grass and nettles grow rankly, and you watch and wait there quietly for a few moments, you will be certain to hear the shrill squeaking of these little creatures, and see sooner or later a small grey-brown shape darting in and out between the stems. It is a shrew foraging for food, sniffing here and there with its long keen snout, nosing a beetle from its hidingplace behind a leaf, a spider from its refuge between some grass blades, grabbing a small worm before it can withdraw into the ground, 
and pouncing like a tiger on a fat green caterpillar that falls from a plant. Where there is one shrew there is sure to be another, and soon a second will come dashing along, squeaking shrilly as it crosses the trail of the first. For its size there is no creature so fierce and active as the shrew. When watching a spot where there are three or four shrews, it seems as if the ground is alive with them. One day I saw a shrew slip across an open space, so sitting down on a fallen tree $I$ waited and watched for a few moments. Another soon appeared, a grey-brown shadow sliding in and out of the rustling leaves; then a third dashed across, and yet a fourth, until it seemed as if there must be dozens about, though perhaps there were really not more than two or three, but they came and went so quickly it seemed as if there were a great many running to and fro. Whenever one crossed the path of another their shrill squeaks rose on the still air, but I saw no fighting (though they often fight like little demons), but it seemed they were busy looking for food and had no time for any thing further than rude remarks. But they abused each other all the time-squeak! squeak! squeak! they went as they raced to 
and fro. The sound was not only very shrill, but, unless one saw the shrew that was making it, it was almost impossible to tell from whence it came, whether before, behind, or from the side of you.

Watching this colony made me very anxious to know more about these queer little creatures, but the first two or three that I caught simply raced round and round the cage until tired out and then died. Two or three hours saw the end. It seemed so cruel that I said I would never try again, but one day a man who was cutting some long grass in the garden came across a shrew and somehow or other managed to catch it. When I saw the tiny creature I decided to have one more try, though afraid that the wee thing must have been pinched in the man's large rough hand. I dropped it into a glass-sided fern-case, in which I kept some frogs, a blindworm, and two or three kinds of toads. The shrew hesitated for a moment, letting me have a good look at it. It was a full-grown young one, being clad in the light brown coat which distinguishes the shrews of the year from those that have lived through the winter. The latter are much darker and have almost bare tails. It is a 
curious fact, but if you set traps in the early part of the winter you only catch shrews in the light fur, there are no old ones about. Now in the autumn there are plenty of old as well as young ones, and many of them die, and you see them lying about on paths and roads. Nearly all these dead shrews are in the dark fur. So many die that in olden days it was believed that the very fact of trying to cross a path was fatal to a shrew. Of course this was merely rubbish; shrews are very delicate little creatures, but they can scamper across a road without being any the worse for it! Yet that great numbers die in the autumn is a fact. It has been suggested that these animals are like so many plants and live only for twelve months, i.e. are annuals. ${ }^{1}$ The idea is that the young shrew wears throughout the summer in which it was born, and on into the autumn, the light grey-brown coat, after which it moults and appears in the dark brown fur. In this dress it breeds, rearing one or two families, after which, its work in the world being now done, it dies. Certainly the facts fit in well with the theory, and account for the strange way shrews die off in the autumn,

1 E. L. Adams, Wild Life, vol. i. p. 82. 
which they do to such a remarkable extent that one can understand how in the ignorant days long gone by, when people believed in witchcraft, magic was called in to account for it.

In the days when everybody believed in witches the poor little shrew was regarded as a very evil creature. If a shrew chanced to run over the leg of a horse or cow when one of these beasts was lying out in the field, the animal would certainly go lame afterwards; while if a horse or cow was bitten by one (fancy a tiny shrew biting a horse !) it would at once swell up and die. Some of the remedies for the bite of a shrew were still more extraordinary, one being to take the body of a shrew which had died on a cart road, burn it, beat the ashes into dust, mix them with goose grease, then rub it on the swelling, which would at once be cured. The body of a shrew that had been killed hanging in the air effected more cures than one killed on the ground. An ointment, too, could be made from the tail cut off a live shrew, but the tail was no use if taken from a dead animal! The most strange idea of all was the belief in a shrew-ash. A twig from a shrew-ash would cure all sorts of ills, 76 


\section{SHREWS}

and it was made thus : a deep hole was bored into the ash-tree, a shrew was then caught and still living was pushed into the hole, which was plugged up, leaving the unfortunate little creature to die. The tree had for evermore all sorts of virtues and would cure many ills. If a horse, cow, or sheep was suffering from the 'cruel anguish' caused by a shrew having run over it, a touch from a twig of the tree that had been treated in this , way would at once relieve it! In these days we can hardly understand how people could ever have believed such tales, but they did believe them most completely, and many a poor unfortunate little shrew was corked up in a tree to die a miserable death in consequence. ${ }^{1}$

To go back to my shrew: it stood and hesitated for a moment, then it darted away, racing round and exploring its new quarters. It smelt here and there, its little sensitive snout quivering all the time, then it dived under the moss, whence it brought out a worm that had been intended for a frog, ate it, and dived under the moss again. There it discovered the hiding-place of a "mud frog" (a small fat foreigner), but what it did to it I

1 G. E. H, Barrett-Hamilton, British Mammals, p. 102. 
do not know. There was a piercing shriek, the moss heaved, and the frog came out. It sat and looked around, and when the shrew came near it blew out its sides with air until it looked like a balloon. Soon the shrew turned towards it, when, without waiting to be touched, it again uttered that soul-rending cry, which lasted until all the air had been expelled and its sides had fallen in. The frog seemed so terribly afraid-I never knew before that a frog had enough wits to get really frightened-that I picked it up and put it into another case. The shrew then turned his attention to the other frogs, toads, and the blindworm, giving them all such an unhappy time that $I$ had to take them away too. Having now got the case to himself he began to make himself at home. He collected oak leaves and grass with which to make himself a comfortable nest beneath the shelter of a fern. It was very snug and warm, the lining being made of shredded leaves and grass. Here he rested in the intervals of worm hunting, for it was on worms that he lived. One day my brother gave the 'Mighty Atom,' as we had named him, thirty big earth-worms, which he dragged off, one after the other, so 78 
that we thought he had eaten the lot, but, though the 'Atom' had a great appetite, we had for once over-estimated it. Next day there was a horrible smell in the cage, and on hunting about $I$ found the greater part of the worms hidden under the moss. He had killed them by biting off their heads and tails, and they were not only dead but smelling too!

It was most amusing to watch the 'Mighty Atom' dealing with a big worm. He knew in a second when one was dropped in, found it at once, by scent I think, jumped upon it, gave it a bite at the head end, sprang back out of the way of its squirmings, rushed off and rubbed himself in the moss to get rid of the slime, hurried back, bit it again, ran away to clean himself, and as quickly back once more. When he had worried its head end well he would begin at the tail, by which rough handling it would at last be quietened, and when it was really still he would begin and eat. He began at one end, holding the body down with his paws, and chewing along its length. When he was hungry it did not take him long to finish the meal, but when he had the choice of several worms he only ate the fore part of each and 
left the hind. He liked, if he could, to drag his worms under the moss, as there they could not squirm over him and soil his beautiful fur. He was most particular over his toilet, and would lick his coat as a cat or dog does, but he never sat up on his hind legs and washed his face as the true mice do. To go back to the 'Atom's ' food, he soon learnt where it came from, and would come to me when called. From the first he had been quite fearless, and as soon as he found out that a hand put into the cage meant food he would rush from his nest, take the worm, and drag it away. I did not always let him have it at once, when he would hang determinedly to the end and pull with all his might. Many times I lifted him up into the air hanging to the end of the worm; no bull-dog could have been more determined, he even equalled that fiercest of creatures the mole !

The shrew was also fond of spiders, flies, and such insects as could be found. At the end of a few days' 'hand feeding' he became so bold that he would climb on to the hand and try and get up your sleeve. He would not stand any nonsense; if offered an empty hand he would attack one's fingers with all his might and main, biting and worrying like a savage 80 


\section{SHREWS}

little fury. His teeth were too small to hurt, though sometimes he managed to pinch fairly well, but if he did no harm it was not from want of the will to do it !

If lions and tigers were as fierce, active, and fearless in proportion to their size, as shrews and moles are in comparison with their little bodies, what awful creatures they would be! It is only by watching these small animals that one can gain any idea of their untiring energy, intense vitality, and their great pugnaciousness. They are perhaps the most quarrelsome creatures in the world! With strangers it is a case of ' war to the death.' For instance, a second shrew was caught one day, and, as I did not know at that time the trouble which would certainly follow, I popped it into the 'Atom's ' cage. In great excitement the "Mighty Atom" rushed out, followed the newcomer round the cage, and then under the moss. The stranger was an old shrew clad in dark fur, and when I heard a great deal of squeaking going on underground I was afraid lest the 'Atom' should be getting into trouble. All the day the squeaking continued, only stopping towards evening. After that all was peace, and I hoped they were settling down nicely, but 
when the following morning I could only find the 'Atom,' I began to wonder what had happened. I could not find the second, and a careful hunt for it failed to discover any trace. In the light of after experience $I$ have no doubt that the 'Mighty Atom' had not only fought with and conquered the stranger, but had also eaten his foe!

Shrews are not at all particular what they eat, meat, cheese, and such things being taken readily in addition to their proper fare, which is grubs and insects of all kinds. Like many other insect-eating creatures they have very quick digestions, and if short of food soon starve to death. For a shrew an hour is a very long time to go without eating, and a fast of only two or three hours is fatal. This is one of the reasons that shrews hunt by day as well as by night, for food must be got at any cost.

However delicate an animal the common shrew may be, the pigmy or lesser shrew is still more fragile. It is the weest creature that you can imagine. Just like its bigger relation in colour, its body at full stretch is barely two inches in length, that of the common shrew being about three inches when laid 


\section{SHREWS}

out straight. It is a slim mite, too, not being nearly so bulky, and it seems a mere wisp of fur and life rather than a fierce shrew. It is the smallest European mammal, being less in size than even the tiny harvest mouse. Despite its smallness the lesser shrew is found in many places where there are no common shrews. It is the only shrew found in Ireland, where neither the water nor common shrews occur. It has also got to many outof-the-way islands which the other shrews have not reached. Yet in the greater part of England it is not very common. However, if you meet with a very small shrew that has a tail which, compared with the length of its body, is longer than that of the ordinary shrew, you may be sure that it is a pigmy. One of the best ways to find out what mice and shrews there are in a neighbourhood is to hunt about beneath the spot where an owl roosts; here you will find oval bundles of fur and bones, which are the pellets or castings that the bird throws up after every meal. Owls swallow their food wholesale, fur, bones, and all. Then this stuff which cannot be digested is thrown up again, and by examining it you will find out exactly what the owl has eaten lately. 
For instance, I opened twenty-eight castings taken from beneath the roosting-place of a barn owl, and found the bones of forty-four common shrews, two pigmy shrews, twenty-seven field voles, five bank voles, nine long-tailed mice, eighteen house mice, and seven young rats, also the remains of three birds. This was what the bird had caught in twenty-eight nights, for each casting was the result of a night's hunting.

Considering what a fragile little animal the lesser shrew is, it is wonderfully plucky, and to see one attacking a black beetle, which compared with the shrew was no small insect, was an amusing sight. It was a very active beetle, one of those hard, shiny kinds, that can run almost as fast as a mouse, but after a short chase the shrew had it, though the beetle struggled frantically, and it seemed to me that it gave the shrew several nips on its long nose! At last the shrew got a good grip of it and held it down, and while it was still kicking began to eat its soft parts. The beetle was then made short work of, and soon only its hard fore-part and shiny wing cases were left. This same lesser shrew would rush at a worm at least five times longer than itself and which appeared much stronger, seize it by the tail, spring out 


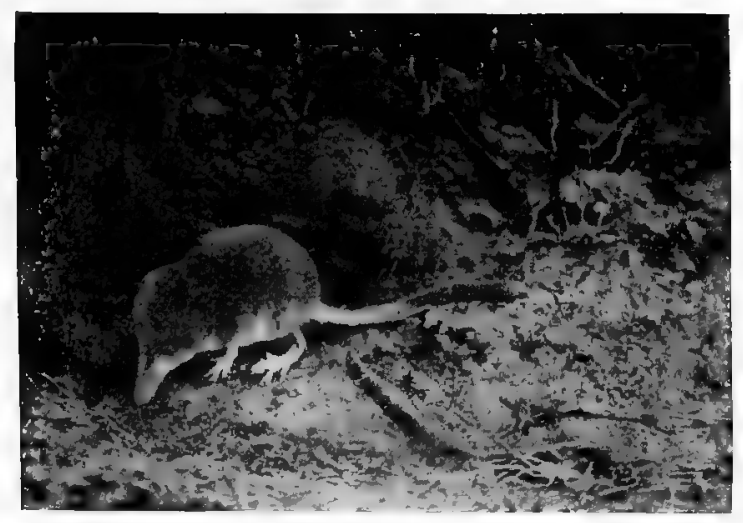

THE PIGMY OR LESSER SHREW

(photographed from life and $\frac{2}{1}$ life size)

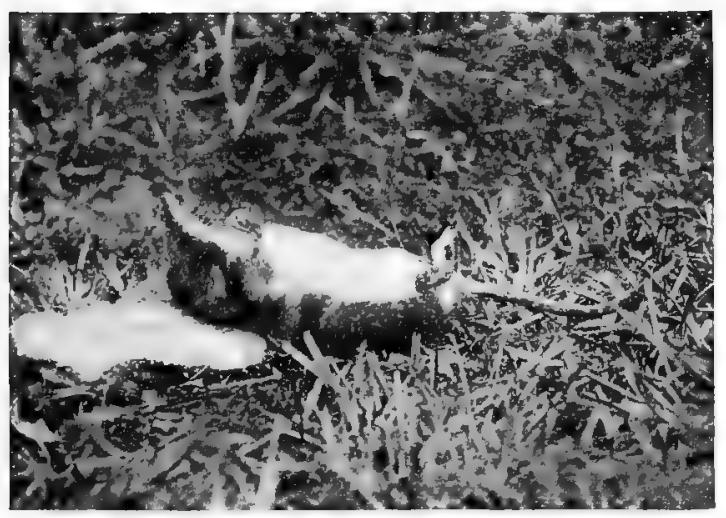

THE WATER SHREW

A specimen that was found lying dead on a pathway, having died mystericusly, as do hundreds of shrews each autumn (1) life size) 



\section{SHREWS}

of the way of its squirmings, jump at its head, give it two or three nips, away again, and another bite at the tail; after which it returned to the head of the unfortunate worm, gave it a fierce tug and pulled it under the moss. Indeed the lesser shrew does not seem to have room for fear in its tiny brain, and will unhesitatingly attack creatures much bigger than itself. The one mentioned above when put for a few moments into the same cage as three bank voles, which had been there for some time and had made themselves a very nice comfortable bed, quickly invaded their nest, turned them out, and made itself at home therein. One bank vole went back to try and turn it out, but instantly there was a shrill squeak, a tiny open mouth showing an array of wee teeth appeared in the entrance, and the vole tumbled backwards in a great fright. As the latter was several times bigger than the shrew, its fear of the tiny stranger seemed rather silly!

The water shrew is quite different from the common and pigmy kinds, being a handsome species, black above, white below, and generally marked with white at the tips of the ears. It is bigger, too, being about three and a half 
inches in length. It is usually found near ditches and streams, being fond of water, as it is an expert swimmer and diver. However, it sometimes comes into the garden, especially if there is a damp ditch beside the fence, and I once found a fine one lying dead on a doorstep, which seemed to have died a natural death as there was no sign of having been caught by a cat. Like the other two kinds it dies in numbers in the autumn, and whatever is the cause in their case affects this shrew as well. As a rule it is only by finding these dead ones that you know there are water shrews about, for it is a shy retiring little animal, and there may be a colony close to your door and you will never know of them. Once, when I wanted some water shrews very badly, I hunted all the streams and ditches for a long way round my home, only to find there had been plenty of them quite close at hand of which I knew nothing whatever. When one does catch a glimpse of a water shrew it is a most fascinating little creature. It comes out of its hole and runs to and fro at the margin of the water, picking its way delicately, then pausing to snuff the air-the 'newspaper' of all animals save man-then it will swim across the stream, 


\section{SHREWS}

floating quite high in the water as it paddles along, so that its body is only sunk to the point where the white fur joins the black, but should anything startle it it is gone in a moment, having dived to the bottom, only a few bubbles showing where it has gone. Under the surface a water shrew looks like a streak of silver, for the bubbles of air that get caught in its fur reflect the light.

It is under the water that this shrew finds the greater part of its food, searching among the water plants, stones, and sticks for grubs and insects, of which there are usually quantities to be found. But it is not particular, and will eat almost anything that comes in its way, including its friend and neighbour if the latter should chance to die! A sad case of this happened to me. With a great deal of trouble I had managed to catch two water shrews, of whose ways at that time I did not know much, so I put them together in one cage, or rather an aquarium. This was arranged with water, a bank, dry leaves, growing plants, and everything that might make the shrews think they were still at home by the stream-side. Plenty of grubs were there, ready so that they should not be short of food, and by putting the two 
together I thought they would have company. One was introduced a little before the other. It made itself at home without any delay, at once grabbing a worm and beginning to eat it; when this was finished it turned to the business of making a bed. This it did by sitting under the heap of dry grass and pulling in the ends all round, in which way it soon had a comfortable domed nest. This did not quite satisfy it; it came out, began to collect the grass that was lying about, which it took back, a mouthful at a time, until it had gathered a good deal and had enough to content it. It seemed quite happy and at home, but all this was changed when I put in the second water shrew. The newcomer was a dull-coloured one, brownish on its under-parts, and without the smart white tips to its ears. The first was a particularly clean black and white shrew. The latter is the most usual type of colouring, but they vary between the two extremes, and the dullest, darkest varieties may be found living in the same family parties as the bright clean-marked ones. Nor are the different types peculiar to different districts.

When the dark shrew was dropped into its 88 


\section{SHREWS}

new quarters it began nervously to sniff about and find out what sort of a place it had got into. Soon the first smelt it; out he came from his nest, open-mouthed, squeaking furiously, and knocked the stranger head over heels! All day long their squeaks could be heard, the newcomer being the one that made the most noise ; but it was eating all right, and seemed none the worse for so much fighting, so I thought they would soon settle their differences and quiet down.

Next morning I went to the shrews very early for fear they might be short of food, and was surprised to find everything still and peaceful. What had happened? Had the second got out, and if not where had it got to? But the truth soon became apparent; a search of the cage revealed the black and white shrew curled up in his nest sleeping the sound and happy sleep of those who have fought and dined well, beside him being the head, tail, feet, and skin of the missing shrew! The little wretch had not only killed his foe, but eaten every bit of him that was worth eating ! And there was no excuse for him, for there were plenty of worms and insects in the cage.

The water shrew lived in solitary state from 
that time forth, devouring worms, spiders, flies, woodlice, bits of rabbit flesh, and even cheese, but no longer able to indulge in a feast on one of his own kind. For a time I kept his cage in the house so as to more fully watch his ways, but he had such a strong musky scent that other people objected, and he had to be exiled to an out-building. Certainly the smell is strong, far worse than that of the common shrew, which indeed to our noses does not smell very much. It seems that the odour of the water shrew arises from the glands behind the shoulders which it has like the other two kinds of shrews. Possibly this smell helps them to find one another, for though so quarrelsome when two strangers meet, family parties will live together in little colonies. Some people think the smell is a protection to these small defenceless creatures, as foxes, cats, and dogs will not eat them, but as it does not stop these animals killing great numbers it is hard to see what difference it makes to the shrews! That their bodies are not eaten makes little odds once they are dead.

All the shrews are exceedingly nimble creatures, running, swimming, and climbing with surprising skill. Perhaps the lesser shrew is the 


\section{SHREWS}

most elegant, being a slim fairy-like mite, while the water shrew appears somewhat coarse and heavy by comparison. It is not only larger, but it is a stouter, heavier animal ; indeed it has many and considerable differences from the common and lesser shrews, so that in scientific classification it is separated from them. Besides these three shrews there is a fourth found in Great Britain, namely the Islay shrew, found on the island of that name off the coast of Scotland; but as it is only found there, we will say no more about it here than to mention that in colour it is somewhat like a water shrew, but is really closely allied to the common shrew, and that it is not found anywhere else in the world. Now the wee pigmy shrew is not only found in most parts of England, Ireland, Scotland, and Wales, but throughout Europe and across the great continent of Asia. It seems that its tiny size must be a help rather than a hindrance in the struggle for life, or else it could not have managed to travel so widely. As a matter of fact the common shrew must also be called a very successful animal, for it is certainly one of the commonest creatures we have. As I have said before, it is found everywhere; no garden is without shrews, and 
here they do no end of good by the amount of insects that they eat. To keep up their numbers they have large families, six, seven, or even more young ones being born at a time. The nurseries that $I$ have found have been under logs, in snug crevices, in banks, and other private corners where the mother shrew could collect a nest of grass and leaves and rear her babies without interference by other creatures. The little ones come into the world as wee, naked, blind, pink morsels, but they grow very quickly and their eyes open; they develop a coat, and are soon able to run about and look after themselves. A second family is by that time engaging the mother's attention, and each pair of shrews probably bring up in the course of a season at least a dozen young ones, before, worn out by all their labours, they creep out from their holes and hidden highways to die in the open. Of those dozen young ones the odds are that but two will live until the next year, to rear families in their turn and launch them into the world. Owls, hawks, cats, and foxes take their toll of the shrews that live on land; that river pirate the pike, even trout at times, and the keen-eyed heron take their toll of the water shrews; so both in the hedgerow and the 


\section{SHREWS}

ditch the same thing is taking place. By these means shrews like other wee creatures are kept from increasing unduly in numbers, and if to us it seems dreadful that death should be always on the watch for them, it seems almost certain that the small animals enjoy their life to its utmost. Most of our fears and troubles come from looking forward to them. If you do not worry about what is to come, but just enjoy the warm sunshine, the good food, the excitement of the hunt after insect and grub, and the sleep when tired in the cosy nest, life must be very jolly. If fear comes as a shadow overhead, or a rustling in the grass, you freeze for the moment, then, the fright past, go on about your business happy once more. When the end comes it is as a thunder-bolt falling from the skies, and carrying off the victim before it knows that danger was near. The sharp pinch of an owl's beak, the grip of the hawk's claws do their work instantly, so there is no old age, no cruel lingering deaths in Nature, and the strong, the healthy, and the fittest go on with their lives happily.

(The British Shrews are-the Common Shrew, Sorex araneus castaneus, peculiar to Great Britain, 


\section{WILD CREATURES OF GARDEN AND HEDGEROW}

but closely allied to the Continental form $S$. $a$. araneus; $S$. granti, the new species discovered on the Isle of Islay; the Pigmy or Lesser Shrew, S. $m$. minutus, which extends from Ireland eastward; and Neomys fodiens bicolor, the British Water Shrew, which is closely allied to the Continental $N . f$. fodiens.) 


\section{CHAPTER V}

TOADS AND FROGS

Frogs and toads are the most useful creatures that we have in the garden, for they eat such quantities of harmful grubs. They are not a bit alike, but as some people are bothered to know which is which, it is as well to remember an easy way of telling them apart, and this is that a frog takes long hops while a toad merely walks. Once in a way the latter will take a short feeble hop, a sort of half-hearted one, but it is nothing to the flying leaps which a frog manages with the greatest ease, and which are its usual means of getting over the ground. Compared with the toad the frog is a very smart fellow; he is daintily marked with browns, buffs, and greeny-browns, the tints varying in shade and depth of colour according to the weather. The country people believe that when the frogs are light in colour there is fine weather coming, but $I$ think the change is brought about by the amount of moisture 
present in the air and not by that which is to come. The frog's skin is smooth and slimy, unlike that of the toad which is dry and covered with little warty lumps. Many people say that a toad is an ugly thing, but if you look at one carefully you will see it has at any rate one beauty, and that is its gleaming jewel-like eyes. They are a pale metallic brown with reddish lights like flickering fires in their depths. No wonder that in olden days silly persons said that precious gems could be found in the head of the toad; there was some excuse for the idle story. Another peculiarity of a toad's eyes lies in the irises, or as we more generally call them the 'pupils.' These are not round like ours, but are narrow and slitlike, and instead of being upright slits, such as we see in the eye of the cat, they are horizontal ones. On either side of the head, just behind its eyes, the toad has a biggish lump, marked on the lower side by a line of deep brown-black. These warts are really a pair of glands, from which when badly frightened it can eject a fluid which causes a burning sensation on tender skin such as that of the mouth, and which makes the owner a very unpleasant morsel for dogs, cats, or owls. This is one of the 96 


\section{TOADS AND FROGS}

reasons why a toad is seldom in a hurry, for he is well aware that though there are many creatures which will eat his relative the frog with pleasure, there is not one that looks upon him with favour. For another thing, he is a fat, squat, portly old fellow, not fitted for racing about, so he does not worry himself, and when disturbed waddles calmly off to find another snug hole in which to hide until nightfall. It is only when some bird or beast makes a mistake and pounces on him that the toad makes use of his defence. He never ejects the fluid except as a last resort-for instance, when hurt or very badly frightened, and one can handle him without any risk of unpleasant consequences. In any case it is not strong enough to hurt our hands, it only being unpleasant in the mouth, and so on. It certainly makes him a nasty mouthful for a dog, fox, owl, or cat; and if one of these creatures pounces on a toad in mistake for a frog, it drops it quicker than it picked it up, and no doubt makes a note in its mind to avoid toads for the future. I once offered a small toad to a young brown owl. The bird took it at once, gave the poor thing a pinch, then dropped it hastily, and, turning round, began to wipe its 
beak on its perch. The owl wiped away so energetically and looked so disgusted that I could not help smiling; but 'Hooter ' evidently saw nothing to laugh at in it, and ever after refused toads, though always pleased to take frogs. I have made the same experiment with other flesh-eating birds and animals, with always the same result. Old and experienced ones refusing at once, young and innocent individuals sampling the toad and then turning away with every sign of disgust.

Though so well protected, the toad is shy and retiring for the greater part of the year. He hides all day in some hole which we may call his den, for it is his home to which he returns each morning after the night's hunting is over. This retreat may be down a mouse hole at the edge of a ditch, under a cabbage plant in the garden, beneath a stone in the rockery, or down a crevice behind your doorstep. As long as he can find a nice damp and really private hole he does not mind where it is. It is this habit that accounts for toads being found in very strange places, and for the accounts given in all good faith of ones which are supposed to have been found in the solid rock or inside a growing tree. Of 98 


\section{TOADS AND FROGS}

course not even a toad could live many hours entombed in solid rock without air, food, or light, let alone the thousands of years that it is sometimes claimed it must have been buried. The explanation is quite simple. What happens is that a toad in search of a good home finds a crack leading into the rock, which being damp and cool suits him exactly, so therein he makes himself at home, living very happily until a time comes when the stone is to be quarried away. The quarryman having attacked it the rock comes tumbling down, when among the bits some one chances to espy the toad. Nobody saw the crack, all see the toad, which was entombed in the solid rock, or at least that is what they say, and so a marvellous tale is told of how the creature must have lived there without air, food, or water for hundreds if not thousands of years! It may be taken as a fact that, however much the people who tell the stories believe them, they cannot be true, as it is a proved fact that a toad must have a certain amount of air, to say nothing of food, to keep it alive.

I have already mentioned that the toad likes his den to be cool and damp. A dry skin is a misery to him, he cannot endure a hot sun on his back; shade and moisture are essential to 
his welfare, which is the real reason that he only roams abroad by night. His skin and tissues are full of moisture, he has special reserves of water inside him, and if kept for long in a hot dry place would soon dry up and die. I have seen a toad which had fallen into a greenhouse pit, and which was lean and scraggy when rescued, swell out in a basin of water, and soon become once more a fat and comfortable-looking creature. The moisture is taken into the tissues by absorbing it through the skin, and that which is lost escapes in the same way. All this explains why the toad dislikes the sun so-why he only comes out when the evening air begins to grow chill, the dew to fall, and the light to fade. Then, with other creatures of the dark, he creeps forth from his den. From the cabbage patch, from the rows of potatoes, from a score or more of hidingplaces, the toads creep forth. Fat and portly people they are, the females being the biggest, and the males a little smaller, but all are stout and thick-set and waddle stolidly along. Now for the business of the night! Those bright, sharp eyes peep everywhere in the dim light, and an insect here and an insect there disappear as if by magic. The deed is done so quickly 100 


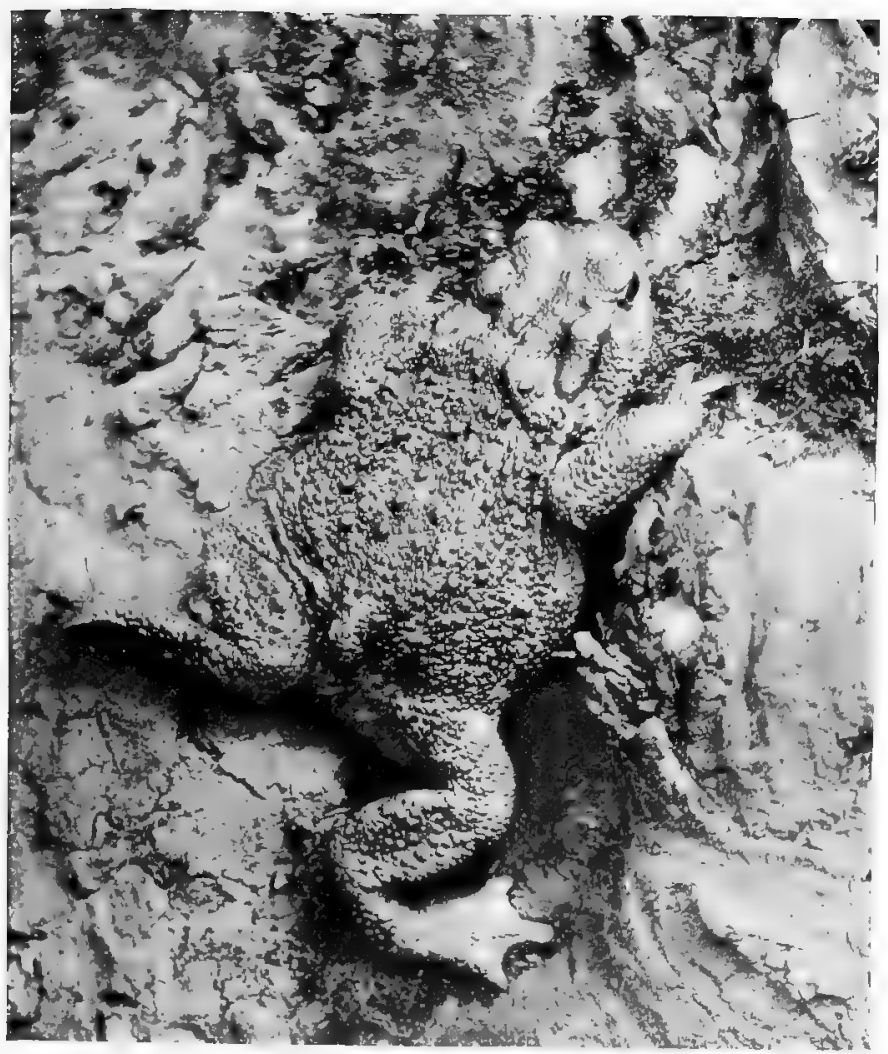

A TOAD CLIMBING 

that one can hardly see what happens. You have to watch very carefully to see the lightning-like flash of the tongue, sticking to the end of which the grub disappears into the toad's wide mouth. Toads, and likewise frogs, have a most peculiar tongue; instead of being fastened like ours with the root down the throat, it is attached to the front of the mouth, and when not in use the long and flexible end lies down the gullet. It is a long extension affair, and can be shot out of the mouth with surprising quickness. The tip is coated with a wet sticky stuff, so any small thing which the toad strikes with its tongue sticks to the end and is drawn back into the mouth. When a toad or frog sees a fly, small worm, woodlouse, beetle, or other insect, it shoots out its tongue at it, seldom missing its object, for it has an extraordinarily good aim, and in less time than it takes to tell is chewing the insect up. The whole thing is done so quickly that the eye can hardly follow the lightning flash of the tongue, and the grubs that thus fall victims are in the toad's wide mouth before they know that an enemy is near. Insect after insect does the toad capture in his nightly round, many of which would have done much harm 


\section{WILD CREATURES OF GARDEN AND HEDGEROW}

to the garden plants, and his sides bulge more and more as he waddles on. He makes his way under the plants, first between the brusselssprouts, then up the broad bean row, next through the lettuces, slugs and grubs getting less at every step, until, the night's work completed, he turns his steps for home. The dawn finds him at the entrance to his den, his sides so swollen with good things that he can hardly squeeze down the narrow hole wherein he will lie, and perhaps dream, all day.

Not only has each toad its own home, but it sticks to that den and its own particular hunting ground for the greater part of the year. It knows its beat as well as we know the districts round our homes, and it makes its rounds regularly every night as long as the weather is mild. With the chill days of autumn a change comes over the toad; it is no longer inclined to wander abroad, and retreats farther into its burrow, actually burying itself if the ground is soft enough to let it sink itself in. Thus protected from frost and snow, it can sleep in peace until the return of warm weather awakens it to activity once more. Probably the real reason of its winter sleep is the difficulty of getting food rather than any 102 
wish to escape the cold. Being a coldblooded creature-that is to say, an animal whose temperature is the same as that of the atmosphere around it-the toad would not feel cold like we do, for it has no heat to lose. Apart from being actually frozen, chilliness does not annoy either it or the frog, but the absence of all insects is much more serious, for food they must have if they are to go about as usual. The only way to get over the difficulty is to go to sleep while there is nothing to eat, and slumber soundly until grubs are plentiful once more.

With the return of life in the spring, when all the wild world is mating and nesting, a change comes over even the toads and frogs. The latter feel it first; even as early as March, while there is still ice in the early mornings on ponds and ditches, they journey off to the water. They are very quiet about it; you seldom see them travelling, and the first one knows of it is when masses of jelly-like spawn appear in the pools. Now the toads make no secret of their business; secure in the fact that no creature will willingly interfere with them, they journey by day as well as by night. The first warm shower that falls early in April 
starts them off. Every toad in the countryside is taken with the same madness-they must all reach water cost what it may! The strange part is that it is not every. ditch, pond, or stream that will do, but one particular pool to which they all make their way. Why some one pond should be chosen I cannot tell you, but water which is apparently perfection will never be used, though another pool not far off will swarm with toads, and it does not follow because frogs use a pond that toads will also come to it. By my home are a chain of pools, five in number, and to two of these the toads come in thousands, but the others, which as far as I can see would do just as well, are never used at all. From far and wide they come to the chosen ponds. What is the farthest that they come I cannot say; all I know is that no other pond is used by toads within a mile and a half and perhaps farther in any direction, so many of these toads must have travelled a mile or more, which, compared with the size of the creature, is a great distance. How do they know where these pools are, how do they find their way? They most certainly have never been near them since the day when they left the water and set about as miniature toads 104 
to earn a living on dry land. The greater number were but tadpoles last time they were in that water. However, they do find their way back, and the only answer we can make to the question, how do they do it? is to say by instinct! Which is not a really good answer, for we know so little about how instinct works that it is much like saying that we do not know.

At any rate we know that a common impulse sets all the toads over a wide district travelling to one particular piece of water; that many meet with mishaps by the way, being run over by carts, trodden on by cattle and horses, etc., etc., but a very great number arrive safe and sound. This past spring I tried to estimate how many there were in the ponds just mentioned, but they defied all counting. There were many thousands; the water seemed alive with them, and no one who had not seen them could have believed that there were so many toads in the district. Now frogs when spawning are very shy, diving to the bottom of the water the second any one comes near, but the toads, secure in their nastiness, are not so shy, but float about on the surface, singing until the air is filled with their croaks. It seems strange to speak of the croaking of toads as singing, 
but such it really is, just as much as the voice of a bird is a song.

Soon the rushes and under-water plants are hung and roped about with strings of spawn. The eggs of the toad are in long ropes, each consisting of a double line of black specks embedded in a jelly-like substance. Frog's spawn is always in masses, each egg being a ball of jelly with a black centre, which is attached on all sides to other balls. In the strings belonging to the toad the jelly of one egg is merged in that of the next, so that there is no clear line between them. It is just a rope of gelatine with black spots, about the side of the top of a black-headed pin, embedded in it. These black beads are the future tadpoles. Each pair of toads produce anything from three thousand to six thousand eggs-we will say for the sake of argument about five thousand; and as every pair in the pond does the same you get some idea of the millions of little tadpoles that will presently hatch out! From this we get some conception too of the great loss of life there must be in the toad world despite the toad's protection from flesheating birds and beasts; for on an average, out of those four thousand or five thousand eggs, 106 


\section{TOADS AND FROGS}

only two young toads will live to grow up and come back to the pond to breed in their turn! All the rest die by one means or another before they come to maturity. But before going into the question of all the dangers that the wee tadpoles have to face, I must mention that the old toads have a water-side foe which wages war upon them, and that is the common brown rat. So far as I am aware, the rat is the only creature that will attack and kill the common toad, though even then it does not do so for food, the bodies never being eaten, but merely for mischief. I have seen the corpses of scores of toads lying in heaps at the water-side, killed and their middles torn open, but no part eaten, while the tracks around in the soft mud told only too plainly the story of the murderer. The common rat is nearly as much at home in the water as the real water-rat or water-vole; but the latter is a very harmless creature and never interferes with toads or anything else, living chiefly on grass and leaves.

A week or more passes, and then the toads, their spring madness over, leave the water as suddenly as they came; one day the pool is full of them, the next they are gone, and it knows them no more until April comes round 
again. In the meantime those who have survived the troubles and dangers of the great adventure are journeying home, but more accidents happen before they get safe to their old quarters, such as tumbles into deep ruts, whence escape is impossible, and a blazing sun brings the prisoner to a miserable end; being crushed under foot by passing beasts and men, etc.; but however many are lost by the way, there are enough tadpoles coming into the world to make up for all accidents.

In a week or longer, according to the temperature of the water, the tadpoles begin to hatch. The jelly absorbs the water and swells greatly, the black beads get larger, and a slit shows at their sides; then they become more like miniature dumb-bells, by which time they have worked up to the surface of the jelly, through which they push their way, falling on the mud at the bottom of the pond as very tiny tadpoles. When first hatched frog tadpoles have quite good tails, but toad tadpoles when newly emerged have hardly a vestige; however it grows very quickly, and is soon quite useful to steer with. At first the little things just lie where they fell, but soon they begin to wriggle about, and then to swim. In their early stages they breathe by 


\section{TOADS AND FROGS}

means of gills which absorb oxygen from the water; but as they get older these organs are absorbed, lungs develop in their place, and the tadpoles have to swim up to the surface and get a supply of air whenever they feel in need of it. To begin with, the tadpoles only eat vegetable matter, but with increasing age they develop a liking for something stronger, and eat any animal matter they can find, including each other when food gets scarce! This is sure to happen among those kept in a jar or bowl unless they are well fed. A few bits of meat dropped in will prevent such tragedies. Many a tadpole falls a victim to its friends in this way, and there are other ways in which they come to an untimely end. There is the grub of the great water beetle, which is a most fearsome creature, being a perfect tiger among the lesser things of the watery world. It has a pair of strong jaws, and when once it has grasped a tadpole in them it never lets go until it has sucked its life juices dry. The water beetle $^{1}$ is itself a danger, perhaps an even greater one than its grub, for it too sucks the life juices from tadpole after tadpole. Another monster, which lies in waiting among the water

1 The great Water or Tiger Beetle, Dytiscus marginalis. 
plants, or hidden in the mud, and clasps in a fatal embrace any unfortunate tadpole that comes near, is the water scorpion, ${ }^{1}$ a flat-bodied brown insect that you would never notice as it lies waiting for its victims. Many other creatures also prey on the tadpoles, but there are such numbers that their ranks are not even thinned. In the ponds, of which I wrote a page or two back, they are so many that the water in places is blackened by them. Sometimes a stream of tadpoles will set out from one bank of the pool to swim to the opposite side, when they will appear like a dark ribbon across the pond. Then you will see another lot swimming along the side. What causes these movements I cannot say, unless it is changes in the temperature of the water. Perhaps they have their own reasons which we cannot understand. No doubt if a being from another world was to look down on a London street from above, he would wonder why the queer little things in the streets below him went all one way on one side of the street and the opposite way on the other side. It is the toad tadpoles of which I am speaking when I mention the crowd movements, for the frog

1 The Water Scorpion, Nepa cinerea. 
tadpoles are more independent and move about separately. I have not seen them take part in these to-and-fro migrations, but each one goes its own way as suits it best. The two kinds can easily be told apart, even in the water, as the toads are always smaller and darker, being almost black. Those of the frogs grow very fast and become a lighter brown.

Both kinds soon begin to develop legs, the hind ones growing first. If you should find a fawn-coloured tadpole with its fore legs well grown and the hind ones hardly showing, it is neither a frog nor a toad tadpole but that of a newt. In the young of the toad and frog the hind legs are well developed before the fore legs begin to show. In these early stages it does not matter to the young creature if a friend or enemy chances to nip off a toe or two, or even its leg, for they will grow again at once! When the fore legs are well grown a further change sets in; the long tail gets less and less, it is being absorbed into the body, and every day the tadpole becomes more and more frog-like. When only a vestige of tail is left, a further change takes place, and this is in the future frog's, or toad's, outlook upon life. A day or two before it had no thought of any 
place but its watery world; suddenly it has begun to crave for dry land. The first showery day or damp evening that occurs after that finds it making its way over the muddy margin, and thence to the shelter of the pond-side reeds and rushes. It is no longer a tadpole but a wee toad or frog about a quarter of an inch in length. Many hundreds lose their lives at this stage, tumbling into the footprints of horses and cattle which, baked hard by the summer sun, have become wells from which such tiny creatures cannot escape. Those that get past the footprints in the mud by the pond have cracks in the ground and other pitfalls to negotiate; but a certain lucky proportion get clear away, and, living on tiny insects, thrive and grow up to become in their turn the parents of countless thousands of tadpoles.

It is worth mentioning that if tadpoles do not get enough to eat they may, instead of growing up into frogs at once, remain tadpoles throughout the following winter. I knew a case of this happening in a basin in a greenhouse. The tadpoles being very short of food were not able to grow, and it was the following spring before they became frogs, but this of course is most unusual. 


\section{TOADS AND FROGS}

Frogs are altogether more lively creatures than toads; they not only take flying leaps instead of proceeding at a sedate walk, but you will find them abroad in the daytime in damp places. This seems rather risky on their part, as so many birds and beasts like them for a meal. Owls, buzzards, badgers, and polecats eat them greedily. Snakes too catch frogs, though sometimes in captivity they will go on hunger strike and refuse even the nicest of small frogs. I remember one grass snake, a particularly nice one, which would not eat, and I had to catch small frogs, kill them, and then stuff the bodies down its neck. At last it got tired of forcible feeding, and ate just when I did not want it to. Thinking it was quite safe with frogs as it would not touch them when offered, and being short of room, I put it in the same case with some green tree frogs, but in a few moments heard a curious noise and hurried to the cage in time to see the last of my little frogs disappearing down the snake's neck! I was too late to save it. The noise I had heard had been its last gasping cry.

The common frog is a very prettily marked creature, with its varying shades of greenybrowns, buffs, bright browns, and not only do 


\section{WILD CREATURES OF GARDEN AND HEDGEROW}

different ones vary very much, but the same frog will differ from day to day, the change being apparently due to the amount of moisture present in its surroundings. Toads too can change colour, and one, which the first day was a pretty mixture of buffs and browns, was on the second, after being kept for the night under a flower-pot, almost black in tint. I then returned it to the spot from which it came, and on the third day it had faded back to its original hues.

Pretty as are the markings of the common frog, they are nothing to those of the edible frog, which is beautifully decorated with bright green on its back. It is about the same size, and in most other respects is very like the common frog; but the bright green at once distinguishes the two kinds, not that any one is likely to confuse them, as the edible frog is not plentiful in the greater part of England, being only found in one or two places in the eastern counties. It is, as may be guessed from its name, the kind which is cooked and eaten abroad, and which is said to be so excellent; but I cannot speak from personal experience, as the two or three edible frogs which I have had were far too interesting and amusing 
to be killed and cooked. This kind has a most musical croak, which far better deserves the name of 'song' than the somewhat harsh melancholy notes of the toad. But it must be remembered that the croaking of all frogs and toads is a love song!

Besides the common toad we have only one other kind of toad in England, and that is the natterjack. It is much smaller, a rather light grey in colour, and has a pale stripe up its back. This whitish stripe distinguishes it at once from even small light-coloured examples of the ordinary toad. It is quite a pretty little creature, and not so squat and solid looking as our better known friend, but just like the latter in its ways and behaviour. It is not very common, and is usually found on sandy soils.

To go back to the subject of tadpoles, if any boy or girl wants to know something about their development, nothing is simpler than to put a few in a basin, which is better than the time-honoured jam-jar, and therein watch them grow and change. If a little gravel is put at the bottom and some water weeds planted in it, they will keep the water pure and it will not want changing. After the first week or 
so the tadpoles should be provided with tiny bits of meat as food, for if this is not done they will be sure to eat each other! The smaller ones go first, and then the bigger, until only one or two fine fat tadpoles are left to tell the tale. When their tails begin to shrink a stone should be put in the basin so that the wee frogs may have an island to climb out upon when they are ready to leave the water. Don't, however, do what I once did. I had a lot of tadpoles of which I was very proud, having taken a great deal of trouble with them and reared them to the stage when they were just becoming frogs. I made a delightful island for them to land on, having found a big stone with holes in it, which would hold soil, so that I was able to plant small ferns and other little plants on it and make a most realistic island. The tiny frogs, with their stumpy tails not quite absorbed, seemed to like my arrangements; they came out of the water and sat about under the ferns. Unfortunately on the second morning after they had left the water I had to go out for the day. The bowl and its contents were left in a window, which in the morning was nicely shaded, but which I forgot received the full blaze of the afternoon 116 
sun. Even now the horrid tragedy that I found when I got home comes vividly back to my mind. The island was dry and brown, its ferns and mosses withered and dead, and, worst of all, the poor little frogs dried up and dead too!

So my advice to those who wish to rear tadpoles is, do not leave the bowl where the sun may shine upon it, and, as the little frogs are difficult to find the right sort of food for, let them go as soon as they are frogs.

(The particulars of the British Frogs and Toads are as follows:-Rana temporaria, the Common Frog, plentiful everywhere; $\boldsymbol{R}$. esculenta, found in a few places in the eastern countries of England, and probably originally introduced from the Continent; the Common Toad, Bufo vulgaris, numerous throughout the country; and the Natterjack, $B$. calamita, which is found in widely separated parts of the country, but is nowhere plentiful.) 


\section{CHAPTER VI}

\section{THE LONG-TAILED FIELD MOUSE}

THE long-tailed field mouse is a very neat, dainty creature, quite a different little animal from the musty-smelling grey house mouse. It has great black eyes looking ready to jump out of its head, large sensitive ears, long quivering whiskers, a sleek slim body, a very long tail, and dainty paws like miniature hands with which it is constantly washing its face, fawn back, and white waistcoat. I have called its fur 'fawn,' but it is really a very pretty shade of light yellowish brown, somewhat darker on the back, where some of its hairs are tipped with black. Though its underparts appear white, it is only the tips of the hairs which are colourless, the bases being grey. One can see this well when the mouse is cleaning itself and parts the fur with its paws. It is a treat to see a long-tailed field mouse washing itself, for it does the work so thoroughly. It sits up on its hind legs, licks its fore paws, and 
rubs with them behind its ears, drawing them forward over the ears, down its face, and over its eyes, in exactly the same way as a cat washes her face. After each rubbing the paws are licked afresh, until at last satisfied as to its head and neck the mouse twists round and begins to clean its back. Parting the fur with its 'hands,' it licks each bit with its wee pink tongue, going carefully over it all. Not a hair is missed, every scrap is done thoroughly, and there is nothing of the 'lick and a promise' about its work. Its back finished, it begins on its stomach, the whole of the "waistcoat' being done as carefully as the rest. Hind legs and feet having been well licked, it then picks up that long tail (and what a long thin tail it is), licks it from base to tip, when, the business completed at last, it is able to give itself a little shake to settle in place the very last hair, and go off about its business the very smartest of well-groomed mice. But should it get a fright of any description, which is very likely to happen, for a field mouse is continually being startled by one thing or another, it will, as soon as it has got over it, begin and wash itself again. Whenever a longtailed mouse is upset it washes itself; if a 


\section{WILD CREATURES OF GARDEN AND HEDGEROW}

moving shadow makes it jump and think that a hawk is going by, it will, as soon as it dares to move, sit up and begin to rub its face with its paws. Indeed this mouse is one of the cleanliest creatures there are, for even a person would be considered extra particular if he or she washed their face more than three or four times in the day!

Though a 'field' mouse, you must not mix the long-tailed field mouse with the meadow vole, as they are two very different animals. It is very easy to get confused between them, as some people call the latter a 'field mouse' too, but they are not a bit alike as far as looks go. The meadow vole is a little short, rough, furry person, with a mere scrap of a tail, and it only eats green food; the long-tailed mouse is bigger, very slender and elegant, with quite a short coat, moreover it will eat almost anything. Indeed they are not alike in any respect except their names, and do not even live in the same spots, the vole keeping to the meadows, while the long-tailed mouse is found in the hedgerows, cornfields, woods, stackyards, and last, but not least, in the garden.

What mischief a mere mouse can do only those who have been bothered by these small 


\section{THE LONG-TAILED FIELD MOUSE}

pests can imagine. Last spring they waged war against my peas. I planted a long row of a new very special sort which I was anxious to try, but never one came up. When I looked carefully at the soil I found many tiny holes had been dug, and on turning the soil over it became apparent that every pea had been scratched up and eaten! That night I set some traps ; next morning the culprits were there, and they were all field mice. Later on, when more peas had been planted, had grown up, and podded well, I was annoyed to find that the peas were being eaten in the pods. At first I thought that birds were to blame, then I thought it was rats, and as a matter of fact rats were mixed up in the mischief, but the field mice were as bad. Traps set by the rows caught quite a number that had been enjoying themselves on the peas. They had run up the sticks, and had either eaten the peas where they hung, or bitten the pods off, and eaten them afterwards on the ground.

The long-tailed mouse is a wonderful climber; it is almost as much at home up aloft as the dormouse, whose home is in the bushes. I have seen a long-tailed mouse run through a briar bush, then jump to the overhanging branch of a 
small tree, where it sprang from twig to twig with the ease and certainty of a creature that had no fear of falling. All the same I did once see an accident. There was a small round nest of honeysuckle fibre and nut leaves in a bramble bush which had evidently been built by a dormouse. Thinking the dormouse might be at home I poked the nest to make sure, when out shot a long-tailed field mouse; it was in such a hurry that it missed its footing, slipped from the prickly briar stem, but was brought up short by a thorn catching its tail. For a second it hung hitched up by the skin of its tail, then with a wriggle and kick got free and vanished from sight.

This mouse is very fond of taking possession of a ready-made and furnished nest, whether a dormouse's, or one of those domed nests made by the chiff-chaff and wood wren. Indeed in the autumn you will find more dormouse nests with long-tailed mice living in them than you will find occupied by dormice. I shall long remember the first time that I found a long-tailed mouse in a dormouse nest, for, seeing the small neat round nest in a bush, I poked my finger in to see what was inside only to pull it back in a hurry, something which 122 


\section{THE LONG-TAILED FIELD MOUSE}

felt like a sharp thorn having run into it. As I drew back a long slender mouse jumped out, scurried off along the boughs, and was lost to sight among the leaves. Meanwhile I was sucking my finger and thinking what sharp teeth that mouse had had! In many cases I am sure the long-tailed mice not only take possession of such empty nests as they may come across, but turn the owners out of nests that they are living in. I knew of an old dormouse and young ones that were happy in a nice nest in a honeysuckle-draped nut bush, and whenever I passed I would shake the bush very gently, whereupon the old dormouse would pop to the opening and look out to see what was the matter. One day, instead of the lovely furry yellow head of the old dormouse, the sleek pointed face and beady black eyes of a long-tailed mouse appeared in the opening. But he did not stop to look at me, and was racing away in less time than it takes to tell. However he was not easily frightened from a comfortable home, and next day was back there again.

It is chiefly in the autumn that the longtailed mice practise climbing and make their homes up aloft, for then there is so much 
food to be found among the bushes, the hazels are loaded with nuts, and the hedges crimson with hips and haws, so they climb up, going out to the very ends of the branches, and there gather the nuts and berries, carrying them down to feast on and enjoy below. More often than not they carry their booty to some convenient bird's nest, which, deserted since the spring, becomes useful once more ere the winter storms tear it from its place between the forking branches. If you walk along a hedge and note the number of old nests filled to the brim with the red and orange fragments of the hips and haws, you can get some idea of what feasts take place when the berries are ripe. Using these dining tables, the little rascals sit up with their booty clasped in their paws and gnaw away as hard as they can, scattering around them the bits for which they have no use, which crimson remnants will tell the tale next day of the joyous dinner of overnight.

With acorns, nuts, and other things which can be stored for future use, the mice are more careful. Nearly every long-tailed mouse has its underground home to which it can take treasure-trove. When they sleep in nests up 


\section{THE LONG-TAILED FIELD MOUSE}

aloft, it is only a matter of camping out for a few days, wet or windy weather quickly sending them home to the snug holes underground. It is in the farthest corner of these that they lay up stores for the lean days of winter, when it is difficult for wild creatures to find food, especially a keen active little mouse which, unlike some other creatures of its size, never thinks of sleeping through the cold hard times. Nuts, acorns, and grain if it can be had, are all carried in. Sweet chestnuts are much liked too, and the minute the nuts begin to fall long-tailed mice make for the chestnut trees. Indeed all mice are very fond of sweet chestnuts, and $I$ have trapped under a chestnut tree in the middle of a wood not only long-tailed mice and bank voles, but also a house mouse! Perhaps the most long-tailed mice are to be found in the corn fields. As soon as the grain begins to ripen they leave their quarters in the banks and hedges and go out into the fields. Each mouse digs itself a hole about eighteen inches long, from which it can raid the surrounding grain. Here it lives and fares even better than its friends that have stopped in the woods and hedges. There is food on all sides of it, grain which daily grows more 
golden as it waves in the breeze, until there comes a morning when the rattle and roar of machinery in the field tells that the reaper-andbinder is at work. Soon the yellow forest, which towered so high above the mice that ran between its stems, is cut, and lies bound in neat sheaves in orderly rows across the field. The world of the long-tailed mice is changed, light floods in where but a short time before was shade and safety from hawk and owl. It is the latter which is to be feared most, for the long-tailed field mice, being creatures of the dark, are not, as a rule, out when the kestrel is hovering overhead. But the birds of the night take their toll : as the dusk falls the barn owl floats by on silent ghostly wing, beating this way and that across the stubble, so that little escapes its wonderful eyes. It is as noiseless as thistle-down blown before the wind, and as watchful as the best of cats. Should a mouse dash across from one stook to another, if one creeps out to pick up some grain, then the barn owl drops, falling to the ground with open wings, more like a kite of which the string has broken than a bird of prey stooping at its victim, but beneath that spread of downy wings a mouse is kicking its 126 


\section{THE LONG-TAILED FIELD MOUSE}

last kick in the relentless grip of the hunter of the night. The owl draws its wings together, stands up, takes the mouse by the head, gives its skull a sharp pinch, gulps the body down head first, pauses for a minute with the tail hanging out of the corner of its beak, gives another gulp, gets the tail down, looks thoughtful for a moment, then shakes itself, takes to the wing, and is gone to look for another mouse. So it goes on until satisfied, and many mice disappear never to be seen by their friends again. All the same, numbers of long-tailed mice live out in the fields well on into the winter, or at any rate the late autumn, for the scattered pieces of corn afford them good living for a long time. At last food gets scarce, the stores in the holes get low, no more grain is to be found in the stubble, the ploughing has begun too, so the mice begin to move. Then it is that they come to the houses, out-buildings, and gardens. Every winter they come to my home, getting even into the house, and sometimes committing suicide by tumbling into the milk pans in the larder! But the mice that do this are not the ordinary long-tailed field mice, but a larger kind known as the yellow-necked mouse. This one is larger and handsomer than 
the common long-tailed mouse, its colours are brighter and cleaner, and across its throat is a band of yellow like a collar, to which it owes its name. In the smaller kind there may be a spot of yellow on the chest, but there is never the complete band, and more often than not there is not even a spot of buff. The smaller mouse looks dull and dark when put beside its big relation. At one time these two types were thought to belong to the one kind of mouse, one scientific name was considered enough, and big and little were known as Mus sylvaticus, or the 'mouse of the woods.' As long-tailed mice are found in all sorts of places, besides coverts, this was not a good name; however, as it was that first given it has had to be kept, and to this day the smaller long-tailed or wood mouse is known as sylvaticus, but now the bigger type has a name as well and is called A. flavicollis wintoni, or the yellow-necked mouse of de Winton. This is because it was Mr. de Winton who first recognised that the mouse with the yellow throat was not only bigger than the other long-tailed mouse, but that each kind kept to itself, and did not mix with the other. ${ }^{1}$

1 W. E. de Winton, The Zoologist, vol. xviii., 1894, p. 441. 128 


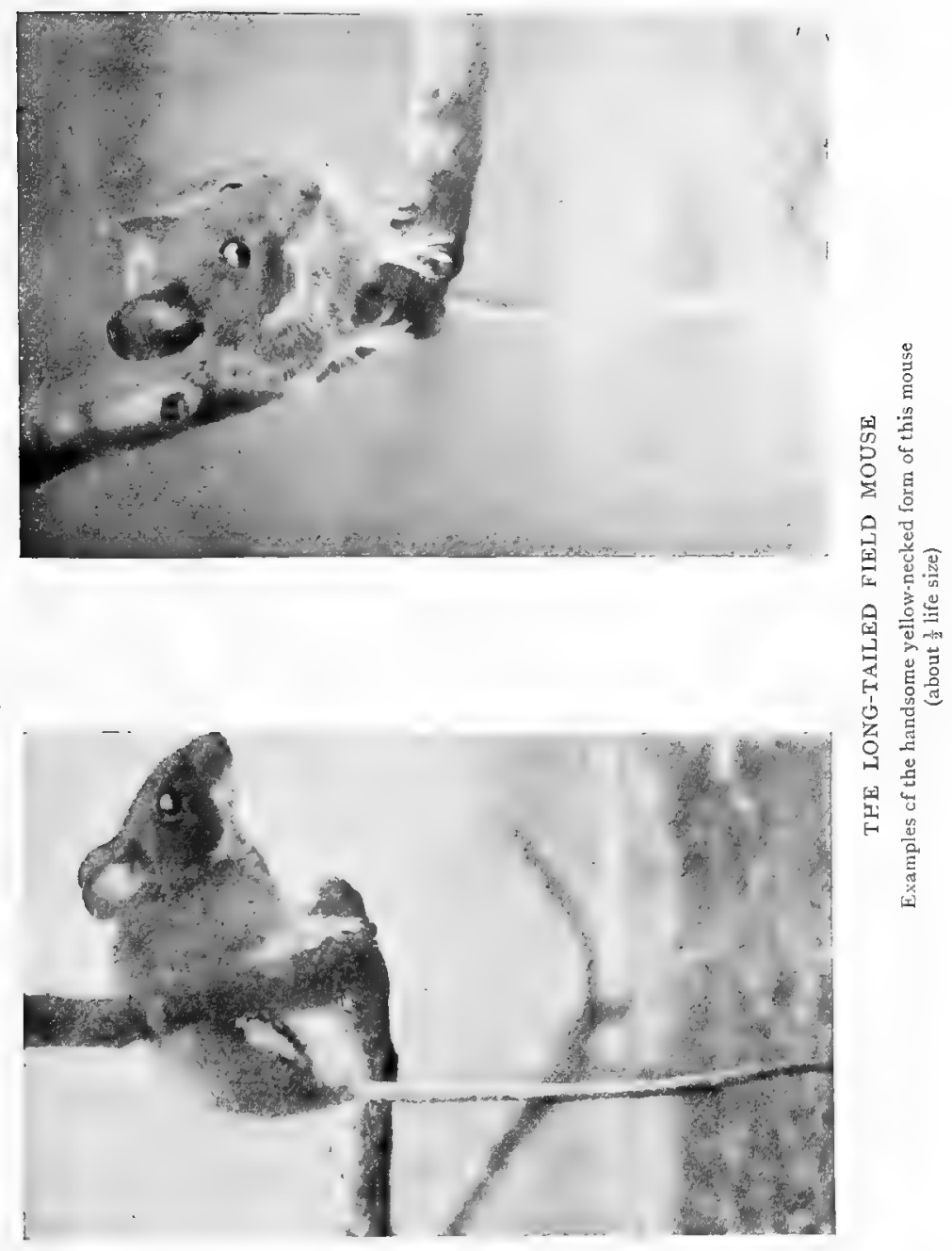





\section{THE LONG-TAILED FIELD MOUSE}

Now here in Shropshire where I live the two sorts are equally common; both invade the kitchen garden and steal all they can, but only the yellow-neck is bold enough to come into the house. Of the scores of long-tailed mice that have been trapped in the cellars, dairy, and larder, not one has been of the smaller kind, but all have been the bigger. What handsome mice they are!-more like small rats than real mice, or shall we say small kangaroos, for there is something nasty about the word 'rat,' and these mice are altogether charming with their dainty ways, while their jumping powers remind one of the kangaroo. When put in a cage with a wire roof eighteen inches high they will spring up to the top in one high hop, and, clinging to the netting, run about upside down. Two of the finest that I have caught were taken in an ordinary ' catch-'em-alive' trap.

There is a holly bush against the wall of the house, and I noticed one morning that something had been eating the berries, carrying them from the tree to my window-sill, and there leaving all the skins and odds and ends. So I got a trap, set it, using cheese as a bait, and left it on the sill. Next morning I found the trap sprung, and wedged inside, without room to 
move, were a pair of the finest yellow-necks that I had seen. They had evidently pressed in together, each no doubt afraid that the other would get that tasty smelling morsel of cheese, and the spring going off they were also caught together. Very often when field mice are caught in ordinary traps their long tails get chopped off by the door as it snaps down; luckily these two had got their particularly long tails quite out of the way, and not even the tips were any the worse for the owners having been trapped.

Writing of their tails reminds me of one thing, and that is, whatever you do, if you should have to handle a long-tailed field mouse, do not pick it up by its tail. That long slender tail looks just the very thing by which to grab a mouse as it is running away, and so I thought when my first one got away. This was when I was quite a little girl. A long-tailed field mouse had been caught by the cook in a trap set in the kitchen, and I know now that it must have been a fine specimen of the yellow-necked race. I was fascinated by the big-eyed beautiful mouse crouching so terrifiedly in the trap. 'Oh! don't give it to the cat?' I begged its captor. 


\section{THE LONG-TAILED FIELD MOUSE}

'But a mouse isn't any good to you, Miss Frances,' she answered. 'Besides, these "greyhound " mice do no end of harm, they all want killing !'

However, by begging and beseeching I got my own way, and the dainty timid creature, instead of being handed over to the tender mercies of the cat, was left to me to do what I liked with; I even managed to get in addition a very large jam jar from the cook. In this I put hay for a bed and some bread for food, and lastly the mouse, which nearly got away as it was being pushed in !-the bit of wire netting which was to do duty as a cover being only popped over the top just in time. After the manner of its nervous kind the mouse immediately sat up and began to wash its face. More fascinated than ever I watched it intently, its wee pink paws, its quick, dainty movements, its large ears, and those great frightened eyeshow could any one give such a lovely creature to the cat?

For several days the mouse lived in its somewhat narrow quarters, but it was well fed, for I gave it every dainty that I could think of, and every day it grew sleeker and more greyhound-like. 'Greyhound mice' the country 
people call them, and it is certainly a good name, for their long slim shapes do remind one of thin sleek well-groomed dogs. But a jam jar was a small 'thing to keep my greyhound mouse in, and those in authority decreed that either the mouse must be let go or fresh quarters found for it. It was my mother who found the new cage, a big bowl in which fish had been kept; with sand on the bottom, some grass and rubbish for nest-making, and a sheet of wire netting over the top, it would do well. The new abode having been put ready, and all preparations made for the removal, the jam-jar was picked up, its cover taken off, and the whole turned upside down over the fish-bowl. But nothing happened! The mouse did not want to come out; we shook it, at first gently, then more roughly, but still it clung to its home. A still rougher shake, and then it shot out, not into the new cage, but on to the table! With a great spring (it is marvellous how these mice can jump) it landed not only on the floor, but half across the room, and with another bound it had reached the shelter of the bookcase. With a cry from my mother, with a shriek of despair from me, we dashed to that bookcase : peeping from behind 132 


\section{THE LONG-TAILED FIELD MOUSE}

it was a long thin tail! - the very thing to catch the mouse by. I grabbed at it eagerly, but, oh dear!-the horrid feeling! I can remember the shiver that went down my back to this minute, for the tail skinned between my fingers! The mouse was gone, and I was left with an atom of skin that had pulled off like a glove. Never again did I try to pick a long-tailed mouse up by its tail. What happened to the mouse I cannot say-I never saw it again-but perhaps the cat knew. She had always looked upon it as her mouse, and been much annoyed when I drove her away from the jar. Whatever its fate, and I hope it got away out of the window, it left me with a great interest in these charming little animals, which has led me since to try and learn as much as I can about them; it also left me with a firm conviction that the tail is not the right part to pick one of these mice up by. So easily does the skin come off that it seems likely that it is a special arrangement to enable the owner to get away from hawks and owls, for if a bird of prey, seeing something moving in the undergrowth, drops down and grabs at the object, it will as likely as not merely take one of these mice by the tail, when the 
mouse with a wriggle can get free, leaving a much annoyed owl or hawk with a mere bit of useless skin instead of the fine fat mouse that it thought it had caught. As one frequently meets with bob-tailed mice, I think this sort of thing must happen quite often. It has been stated in books that after an accident of this sort the mouse always bites the bare bone off at the point where the skin broke. This is certainly a mistake, for I have had numbers of long-tailed mice which in one way or another had had their tails skinned, and not one of them attempted to bite the bone off, but let it stay until it dried up and fell off of its own accord.

When kept in a cage field mice are not only most charming and interesting little creatures, but they are so good-natured that quite a number can be kept together without any fear of quarrelling. They are not rude and unpleasant to newcomers like the bank voles, who always go straight for strangers and try and knock them head over heels. The long-tailed mice are much better behaved; they are the ladies and gentlemen of the mouse world, behaving not only with consideration, but giving a kindly welcome to complete strangers who may 134 
be put into their quarters. I have often watched to see what would happen when a new mouse was put into a cage where other mice had been living for some time past. In the case of voles-either bank voles or meadow voles-there would have been no doubt at all, for they would have at once attacked the stranger, and fought with it for hours before allowing it to go near the nest. In every case my long-tailed mice have shown most perfect manners as long as the stranger was of their own kind, going up to him, sniffing him all over, licking him, and finally taking him into the nest, where a little later I have found them all curled up asleep together. Very different is their behaviour when yellownecks are put with the smaller long-tailed mice, the bigger kind treating the smaller very badly. This I noticed first when three ordinary longtailed mice were introduced into a cage where a pair of yellow-necks had been living for some time. They were a beautiful couple, the male being as big and bright coloured a specimen as I have ever seen: the newcomers looked quite dull and dingy by comparison. The big mice came out of their nest and sniffed the little ones over, after which there was some 
squeaking, but the fighting did not seem serious, and I felt perfectly happy about them. However, my confidence was misplaced, for next morning one of the smaller mice lay dead on the bottom of the cage, and, what was worse, was partly eaten too. As all mice are given to cannibalism when they find a friend or neighbour lying dead, I did not take much notice of the corpse being eaten, and, knowing what gentle creatures long-tailed mice are, concluded the mouse had died from an accident or a hurt which it had met with before being put in the cage. All the same I was surprised to find that the two other long-tails had made a nest for themselves, and were not sleeping with the yellow-necks. Hitherto my long-tailed mice had always welcomed strangers into the family nest, where they would all sleep happily together, but evidently the yellow-necked mice were not going to have the smaller ones living with them. Next night another small mouse died! Then it dawned upon me that murders had taken place. It seemed that the big mice looked upon the smaller race as quite different creatures, and were not going to tolerate them at all! Having taken away the one which was still unhurt, I thought I would 136 
try how the yellow-necked mice would behave towards such a totally different kind of mouse as a meadow vole, so I slipped one of these into the cage. In a few minutes the male yellowneck came out of his nest, went straight at the vole, which reared up on its hind legs and squeaked; but, though voles are good fighters, it was no match for the great yellow-necked mouse-it was knocked head over heels, and I had to go to the rescue and take the poor little thing away, ere it was badly hurt, for it had already got a bite in the leg which was bleeding freely. Luckily the vole was none the worse next morning, but after that the yellow-necks were allowed to do as they wished and live by themselves. From the way they had behaved, it was evident that they looked upon the smaller long-tailed mice as distinct from themselves, as different indeed as the meadow vole.

Afterwards I got some long-tailed mice and some yellow-necked mice to live together by taking one of each sort and turning them together into a new cage. Being lonely and in strange surroundings they soon made friends. But, though I made up five pairs in this manner, and kept them together for some months, not one of them had a family, which was what I 
had been hoping for. In a wild state it seems fairly certain that these two races of mice do not mingle. I have invariably found when trapping mice, whether in the garden or the fields, that where you take long-tails you do not catch yellow-necks, and vice versa. The only time I have seen two mice together, which could possibly have been one of either sort, was in the case of a couple that invaded a beehive.

It is an extraordinary thing, but nevertheless a fact-indeed among bee-keepers it is a wellknown fact-that field mice are very fond of honey and will rob a hive if they possibly can. They appear generally to make their way in on the cold autumn nights, when the bees are drowsy and not readily roused to danger. I cannot believe that any mouse, even the finest of yellow-necks, would venture near a hive of which the inmates were alive and wakeful, with the sentinels posted at the door ready to attack all intruders. In the case of the hive of which I write it was not until November that it was realised that there was anything wrong. The hive was opened, and in a corner on the top of a bar-frame was a round ball of leaves and grass-a mouse's 138 


\section{THE LONG-TAILED FIELD MOUSE}

nest! I grabbed it, hoping to seize the mice inside. One I did catch-it was a big yellownecked long-tailed mouse-but the second managed to squeeze through my fingers, took a flying leap into the grass, where it was as useless to hunt for it as to search for the proverbial needle in the bundle of hay. As it jumped it struck me as being rather small and dark for a yellow-neck, so it may have been an ordinary long-tail. If so, this is the only time that I have found these two mice living together; but probably it was really a young yellow-necked mouse, as the young ones are duller and darker in their coats than the old ones. It is possible if one can handle them to tell young yellow-necked mice before they get their full coat and colouring, as, even at that early stage, the future yellow collar is there, showing as a dull grey streak across the throat.

To go back to the two mice in the beehive, what mischief they had done! They had eaten the brood comb, the stores of honey, the candy put in as supplies for the winter, and even the bees themselves. They had utterly destroyed them! On the floor of the hive was a piled up litter of bits of wax, crumbled comb, and 
the wings and bodies of the murdered bees. It was a pitiable sight, and, though I am not particularly fond of bees ( $I$ do not consider them very good-mannered when I am passing !), I felt really grieved to see such destruction. As to what the owner of the bees said, well, I think, over that we had better draw the curtain.

Long-tailed mice usually have big families, and I have found five, six, and seven young ones at a time in their nests. Like all mice the babies are born blind, helpless, and naked, but the pink mites grow quickly, and in a very short time have a coat and are able to see and get about. As soon as the members of one family are able to look after themselves the mother turns her attention to another, and litter succeeds litter throughout the summer, so that in a warm dry season when all the babies are reared it takes but little to start a mouse and vole plague. A 'vole plague ' only happens when the weather is suitable, and the natural enemies of the mice, such as owls, hawks, stoats, and weasels, are too scarce to keep the mice down. Then all mice increase and flourish until they eat everything in the countryside, but as a rule such a plague is followed by mice diseases which sweep them away again.

140 


\section{THE LONG-TAILED FIELD MOUSE}

In ordinary times, however, a mother mouse is lucky who rears half her young, for cats and dogs, foxes and other wild creatures, hunt for the carefully hidden nurseries, baby mice being dainty morsels of which they are all very fond. I have found nests in holes underground, on the surface beneath heaps of hedge brushings, under fallen logs, and in old tree stumps.

To return for a moment to the handsome yellow-neck field mouse, I must mention, before closing this description of the long-tailed field mice, that the yellow-necked mouse, though so common in some parts of the country, especially the West-Midland counties, where sometimes it is a perfect nuisance in houses and gardens, is in other parts just as uncommon, and so far has not been found in Scotland or Ireland.

(The Sylvaticus group are most variable mice, and quite a number of species and sub-species are now known from the European area. It is a most interesting feature of our British mammalian fauna how groups of these mice isolated on islands have come to differ from the mainland stock, several new forms having lately been described from the islands off the coast of Scotland. The common Long-tailed Field Mouse of the British Isles, Apodemus s. sylvaticus, is the same as that found on the Continent, 


\section{WILD CREATURES OF GARDEN AND HEDGEROW}

but there is a sub-species $A$. $s$. butei known only from the Island of Bute. The Field Mouse of the Hebrides is regarded as a distinct species from Sylvaticus; it is the A. h. hebridensis of de Winton, and four sub-species of it have been recognised from as many different islands. There is not space to deal with them here. St. Kilda has its own Longtailed Mouse, called $\boldsymbol{A}$. hirtensis. The peculiar Longtailed Mouse found on Fair Island is $\boldsymbol{A} . f$. fridariensis, and there is a sub-species of it found on Yell, and on Mainland, Shetland. The Yellow-necked Mouse of de Winton is nearly related to a similar large mouse found in Denmark, etc., but is sufficiently distinct to be dubbed $\boldsymbol{A}$. flavicollis wintoni.) 


\section{CHAPTER VII}

' THE LITTLE GENTLEMAN IN THE BLACK VELVET COAT '

WHEN the Jacobites drank to the health of the ' little gentleman in the black velvet coat,' they meant the mole over whose heap of soil William of Orange's horse stumbled in Richmond Park, throwing the King, who was so hurt that he never got over the fall. In gardens, allotments, fields, and parks those hillocks may be met with, to the annoyance of the owners, for no one likes unsightly mounds of earth all over the place, yet, despite the fact it is so common, most people know but little about the mole. It lives entirely underground, the well-known heaps of soil being the results of its tunnellings. It seldom comes up to the surface, and then only for a moment or two to gather dry leaves and grass with which to make its nest. It is so shy of venturing up into the daylight that it is seldom a mole is seen alive and unhurt. It seems very strange 
to think of a creature living entirely in the dark, hardly ever coming up to the top of the ground to enjoy the light and air like other animals, indeed actually disliking the light, and going back to its dark tunnels as soon as it can. But the mole is most perfectly fitted for its peculiar life, its body is just the right shape to push through the earth, it has enormously strong fore paws like broad hands on short powerful wrists, which, combined with the great muscles in its thick shoulders, enable it to shovel aside the dirt. It has really no neck, its head being sunk into its shoulders, which makes it very strong and able to lift a big weight on its back. It has short, beautifully velvet-like fur, that can be rubbed either way, and never gets dirty. It has keen hearing, but no external ears for the soil to drop into; a very sharp nose, by means of which it finds the worms on which it lives; and last, but not least, eyes being no use to it in unlit tunnels, it is blind. Its eyes are so very small that they are no good, it is even doubtful if they serve to tell light from darkness. Certainly it cannot distinguish one object from another. These minute eyes are difficult to find; they are buried in its fur, so one cannot see them except 

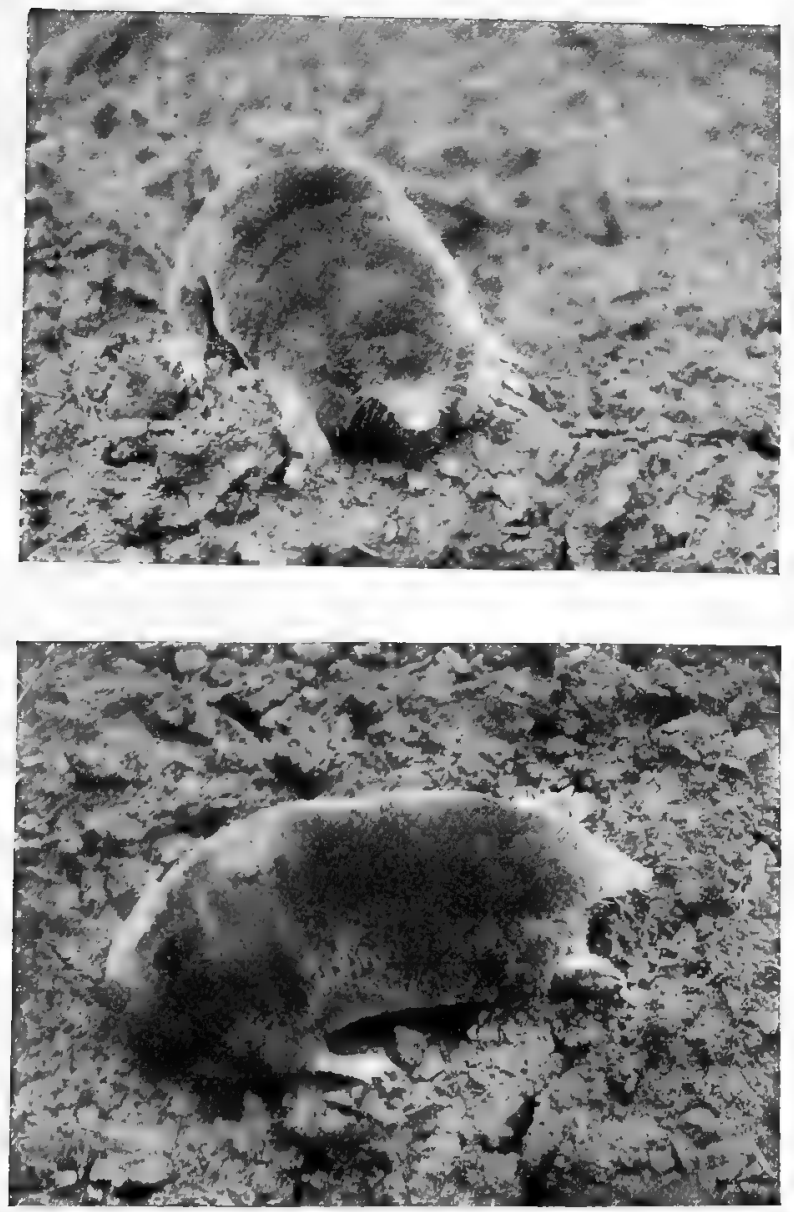

THE MOLE

(갈 life size) 

by looking for them carefully. When you do this tiny black specks will be found, remains of the organs with which its ancestors saw the beauties of the world ere moles took to living in tunnels under the ground. Perhaps it was their keenness for worms that first made them drive holes into the soil, for they eat an enormous quantity. The appetite of a mole is extraordinary, and it has a very rapid digestion, so it cannot go long without food, even a fast of only a few hours often being fatal. I have known two cases of moles being starved to death. In the first a workman, who knew I wanted a mole alive and unhurt, found one when turning over some rubbish, caught it before it could dig into the ground, and, as it was too late in the day to bring it to me, put it in a box, in which he also put some soil. Next morning, at six o'clock, the mole was not only lying dead on the top of the earth, but was stiff and cold as well! The second case was that of a mole that I had caught, and which I fed with forty worms late in the afternoon, yet early the next morning it was dead. On examination its stomach proved quite empty, though there was nothing else the matter with it. The little glutton had 


\section{WILD CREATURES OF GARDEN AND HEDGEROW}

gorged itself overnight, and then starved before morning.

When I got another mole I took care it should never be short of food. It had a daily allowance of sixty worms-and what a business it was to get them for it day after day-but sometimes many more. The average weight of worms eaten in the twenty-four hours was four ounces, or one ounce more than the animal's own weight, which was only three ounces. Had it been kept for twelve months it would have wanted ninety-one pounds, which would mean twenty-one thousand nine hundred worms. As there are often scores, if not hundreds, of moles in an ordinary meadow, think what a huge quantity of earth-worms must be destroyed in England in one year by moles. Besides being one of the fiercest and strongest of animals for its size in existence, the mole must also be called the greediest! When speaking of its appetite it must not be forgotten that the individual of which I write was kept in a tub, so would not get as much exercise as a free one, which would have to travel a long way for its food, and from the exercise would be sure to have an even better appetite! I was very careful to dole out the 146 
worms to this mole, so that it should not eat them all at once and then go short. By doing this it was not only kept alive, but very well and lively. It was quite an accident $I$ got it -a trap had been set in a fence, and I was going by as it went off. I soon let the mole go, but could not hold her (it was a small one and therefore I believed it to be a female), so put her into the only thing at hand, namely, my glove, where she scratched and struggled, squeaking loudly all the way home. It was a funny sound, something like the squeak of a shrew, but not so shrill. The tub being handy I put her in it, covering the bottom with about eighteen inches of soil. First she dashed frantically round and round, trying repeatedly to climb out; then she buried herself, when the heaving told how she was exploring the bottom of the tub. When she went down into the earth she flung the soil out behind her with her hind feet, while her fore paws pressed it back on either side. It is rather difficult to understand how the earth we see heaved up into hillocks in the fields can be thrown out. From what I have seen of moles at work, I think they push forward through the earth, throwing back loose soil behind them, then turn round, 


\section{WILD CREATURES OF GARDEN AND HEDGEROW}

and with their great strength heave and push this accumulation up to the surface, but of course it is difficult to be sure what is done underground.

Some grass and leaves had been put in the tub, and by next day the mole had drawn them together to make a comfortable bed, wherein I could see her lying, curled up into a ball of warm dark-grey velvet, which was beautifully soft to the touch. When she felt my finger she squeaked, rolled over on her back, kicked, then righted herself, and ran off down one of the tunnels she had made. After a few days she got accustomed to being poked and no longer squeaked at the touch of the finger, but merely came out and looked for worms. How fiercely she grabbed each one, biting it quickly from end to end so as to kill it and stop it wriggling, after which she began to eat it from one end, holding it down with her paws, and chewing on until the last bit was gone. Sometimes she would drag her worms into the nest to be eaten, and others were taken underground.

A big mole, a male, that I watched and studied later, would, if he had more worms than he could eat, bite them until they were nearly killed, then bury them, just like a dog hiding 148 
a bone. This second mole was not kept in the tub, but in a glass-sided cage that had been an aquarium. He was only given a few inches of soil, so that it was easier to watch him and learn about his ways and habits. He was much bolder than the first, indeed not at all nervous, soon making himself at home, and learning to take worms from my fingers. He was fiercely eager for food, and when engaged in eating a worm would let one take him by his stumpy tail and raise him in the air without letting go of his prey. Indeed once he had hold of a worm it took a great deal to make him let go. You could, if the worm was a big strong one, take it by one end and lift the mole, hanging on like a bull-dog, high over the cage. His fierce quick movements when dealing with a worm always made me think of a terrier killing a rat. This mole preferred to take his prey underground, possibly to prevent the slimy thing squirming about and messing his beautifully kept fur. I often noticed him when eating scratching first one side of his body and then the other with his hind feet; but, at any rate, his custom was to kill his worms first, then leave them, dig a hole, come back, and drag them down. 
It being more than difficult to keep the mole supplied with all the worms it needed, I tried it with other foods. Tiny bits of meat were tasted, but it was evident he did not like such fare. A chicken's head with the feathers on had more effect, for it roused him to fury. I held it over his nest in which he was asleep. He woke up at once, his pink nose appeared above the leaves sniffing its scent, and then he slipped out of the nest, heaving up the soil, and reappearing near the edge of the cage, where he sniffed again. The feathery thing was just above him. His momentary fright changed to fury, he sprang into the air, grabbed and worried the head, hanging on to it with a determination it is impossible to describe. His savageness must have been seen to be realised, and in the end he had to be pulled off by main force! Another time my brother held a dead mole near the tame one, touching him lightly on the tail with it; round he spun, grabbing the corpse before it could be snatched away, shaking and worrying it like a fury, and evidently very wroth with what he probably regarded as an insult from a foe. Again it was quite a trouble to pull him off, and when dropped back into the cage he simply raced 150 
round it, hunting everywhere for the escaping enemy. He seemed as if 'possessed by a devil !' When the corpse was again held near him he sprang straight at it, getting it by the tip of the nose and holding on like a limpet. He was raised clinging to the dead mole high above the cage, still he held on, using his fore paws to rasp his inanimate foe. Three minutes, five minutes, seven minutes passed, and still he kept his bull-dog grip. At last we pulled him off, when he raced round the cage looking, or rather smelling, anxiously for the corpse, and mad to continue the attack. Had it been another live mole they would have fought to the death!

Many a furious battle must be waged in those tortuous tunnels that are the home of the mole. Imagine the meeting in the gloom, friend and foe recognised by smell alone; the fierce joy and madness of the battle waged up and down the passages; and the victor, torn and bleeding, going home at last to his warm nest of leaves and grass, leaving his enemy still and cold in some dark corner. But not only must many fierce battles be fought between rival males, but other combats must be fought too. Would even the bloodthirsty 
little weasel overcome a mole? I have my doubts! At any rate the mole is not very good to eat, and I think the weasel would probably consider it more discreet to avoid such unsavoury prey. Polecats, ferrets, stoats, and owls all refuse to touch a mole. Perhaps it is the peculiar smell they do not like; at any rate, the fact that foxes will kill moles, roll on the bodies, and then leave them uneaten, seems to point to this. I was once following the trail a fox had left in the snow during his previous night's wanderings, and, after following the long straight line of tracks which told how he had been trotting steadily onwards, I came to more irregular foot-marks. Plainly written in the snow-plainly, that is, for those who understand what is written in pad-mark and trail-was the story of how seeing something moving he had paused, then stepped forward stealthily towards the spot where a mole had been heaving near the surface. The raw red earth made a vivid stain on the clean snow. It was the last soil that that mole ever threw up, for as it came close to the top of the ground the fox had sprung, killed it by a skilful nip, dropped the poor little carcass, sniffed it disdainfully, rolled on it, and gone on about his night's hunting. There 
was the mole, a poor little black smudge in the middle of a ring of soiled and flattened snow. The 'little gentleman in the black velvet coat' had paid dearly for venturing so near the surface.

The only creature which regularly kills moles is the buzzard, which takes many home to feed its young, evidently getting them by dropping upon them when heaving near the surface. But as the buzzard is a bird of the hills and wild moorlands, the moles of the cultivated lands have few or no enemies to fear, and can drive their tunnels far and near with no danger from anything save the molecatcher and his traps. The wonderful velvet fur, which is a special adaptation to underground life, having, unlike the coats of most creatures, no 'set' in any one direction, costs thousands of moles their lives, for it is one of the few really valuable furs that we get in England. The short erect hairs enable the mole to turn and twist, go backwards or forwards in the narrow damp passages, and yet never get really dirty, a shake, a few scrapes with its paws, being at any time enough to make it again spick and span. I sometimes saw my tame mole use his hind feet to scrape the clay from between 
the big claws of his fore feet, and, as I have already said, he hated worms to squirm over him and slime his fur.

The mole in question was not only particular about his coat but also about his bed; indeed a good warm nest is necessary, or a mole will not live long. He had a quantity of leaves and grass scattered about the cage, and his method of making up his bed was to gather a few dry leaves together, then sit on them and pull all within reach around him. Gradually a pile was built up, from which his pink nose would keep peeping out first here and then there, each time pulling in another leaf and adding it to the pile. He never used his paws to shape the nest, but pushed and prodded with his nose, turning and twisting until it was neat, round, and well shaped. When leaves, which he much preferred to grass, could not be reached by stretching out of the nest, he would leave it and run across the cage, his scrap of a tail sticking up impudently, and snatch a leaf, carrying it home with his head high in the air. In the warm and comfortable bed thus made he would sleep for about an hour at a time, curled up into a velvet ball, and sometimes snoring with queer squeaky grunts ! 
Moles in a wild state make wonderful sleeping places, throwing up large heaps of soil, sometimes as much as a barrowful, to protect the nest, which is in a central chamber. These large hillocks, often called 'fortresses,' or ' palaces,' are merely living places, being chiefly used in the winter, and are never nurseries. Sometimes they are under bushes, or in a wood, but quite as often you may see them out in the open. No two have the tunnels inside arranged quite the same, though in old books on birds and beasts it was always said that the mole made its home according to one fixed plan. However, this was a mistake. I have opened many fortresses, and each one has been quite different from the last. There are but two points in which all agree, the first being the central living chamber, which is about the size of a football and situated on the ground level ; and the second the bolt hole which leads from the sleeping place down into the ground. This tunnel goes straight into the ground for eight or nine inches, then curves up again and joins the main run. It serves two purposes, the one to enable the owner to slip out of the bottom of his nest when danger threatens, the other to drain off any water that may soak 
through the thick layer of protecting soil in very wet weather. It is wonderful how dry the fortresses keep as a rule, the bed in the centre being as warm and comfortable as any creature could desire. The lining is made of such leaves and grass as can be found near at hand, the owner continually adding to the accumulation, going up to the surface when all is quiet, choosing by smell and touch the material best suited for his needs, and carrying it home through the many passages. Besides the bolt hole, which is a sort of ' back door,' there are many other ways in and out of the nest, and the heap of soil is riddled with galleries. Many passages radiate from the fortress into the surrounding land, their course being marked at intervals with the earth thrown up as the mole made them.

There are both highways and byways, the former being the roads along which the moles travel from place to place, and which are used by many individuals. These are the ones that the mole-catcher likes to set his traps in, for he can be sure of catching more than one mole in such a highroad. The only thing is that if he catches a mole, and another mole comes along before he has taken it out of the trap, 156 
number two will be certain to attack the body, biting and scratching it until the fur is quite spoilt! The reason of such spiteful behaviour has often puzzled me, but, as has been pointed out before, a mole is one of the fiercest creatures for its size in existence, so no doubt when one of these little animals finds its friend has got into trouble it merely rejoices at a chance of paying off old scores. Despite their quarrelsomeness many moles will live in the same system of tunnels. I have known no less than eighteen trapped in a single highroad, so they must have some way of settling their differences. Probably members of the same clan or family live happily together, but fight and drive away strangers who come into their country. This is so with some kinds of mice, also birds, which are very much annoyed when mice or birds, as the case may be, that they do not know, come poaching on their territory. Well, we are much the same ourselves; we do not mind our friends walking about our gardens, but we are exceedingly annoyed if a stranger comes in unasked !

The 'byways' are the actual hunting grounds, the tunnels being pushed here and there close to the surface as the mole hunts for worms. The main roads are often sunk fairly deep; 
but the others, especially in damp weather, are so near the top of the ground that you can open them up by running your finger along under the grass. Once made they may never be revisited, for they do not lead anywhere, and were made only to find earth-worms. When one reflects on the work done in this way by a mole in the course of twenty-four hours, we get some idea of its great strength and activity, and no longer wonder at the amount of food it needs and eats. It can lift many times its own weight of soil, and I have seen one push out of place on a smooth surface a nine-pound brick. As the animal's weight was three ounces, this is as if a man whose weight was twelve stone moved an object 3 tons 12 cwt.! What weak little creatures we are compared with a mole! No wonder it can heave up soil so easily, and that it is quite difficult to hold one in your hand. A mole's time is spent in rushing about its tunnels (for it can travel amazingly fast underground, and, however awkward it may appear on the surface, is neither clumsy or slow below ground) in search of food, and in short spells of sleep in its warm fortress. Judging from the captive moles I have watched, it does not rest, as a rule, for more than two 158 
hours at a time, but is soon awake and off again to scent out the unfortunate worms. Its activity is entirely governed by them. In wet weather when the worms are at the top of the ground the moles' runs are very shallow; when the worms go deep, it has also to drive its tunnels deep, and during the hot dry summer-time, when they are hard to find, it has to leave the open meadows with their baked soil, and seek its prey in the woods and hedgerows. Under the damp layers of fallen leaves worms abound, no matter how the ground may be baked elsewhere, and here the mole can tunnel happily in search of them, while its winter hunting grounds get harder and harder. It is sometimes said that moles cannot live without water, and that is why they are only found in damp land; but the truth is that their food is only found in fairly damp soil, not that they want water so badly. As a matter of fact I have never seen a mole drink. All those I have had for purposes of study have had water provided for them. More than once I have seen one of them dip its nose accidentally into the saucer and draw back sneezing disgustedly, but I have never seen one drink properly. Other people have 
done so, but I cannot think the mole is really a thirsty creature.

To go back to the 'palace,' it is a curious fact that this elaborate living place is made and occupied by the male alone! The female is not nearly so particular about her quarters. A bed under a small hillock will do for her, but her mate must have his great mound, his comfortable chamber, and his tunnels driven around the heap. Here he lives in state all winter, but with the warmer weather even he becomes less particular, sleeping anywhere he can make a nice nest, and the great fortress is deserted for the time being, though often returned to the following autumn. Some of these mounds are occupied year after year, new bedding being put on the top of the old, or even a new sleeping chamber dug out above the first. I have opened a mound and found the two nests, the old and the new, thus placed one above the other, and a case has been known of a mole palace that had no less than seven nests in it! 1

Not only are the living places of the males and females different, but so are their highroads. The main way of the old gentleman mole will

'Seo photographs by Mr. Douglas English in Wild Life, vol. i. p. 346. 
often go straight across a field, practically without twist or turn, though with a few side runs for hunting purposes. The female does not care about such bold and go-ahead methods; she has a different temperament, she is more timid and retiring, she prefers to turn and twist, to work backwards and forwards until her runs are a confused tangle in which it is as impossible to make out any method or purpose as it is in a ravelled skein of wool. Of course, where moles are very numerous the ways will run one into another; no system is distinct from the next, and the whole field will be covered with a confusion of mole heavings, so that it is likely that even the moles themselves hardly know when they are in their own runs or poaching in those of a neighbour.

The old males are most active and travel more widely during April. Their quarrelsomeness is also at its height, and what happens if two meet face to face can bo best left to the imagination! About the nuiddle of May their mates begin to think seriously of nursery requirements, a matter which does not interest the males in the least. The female mole is a cautious little creature; she retires to some unfrequented corner of her own run, and there 
chooses a nursery. She has no intention of throwing up a great mound to cover her babies, for a warm well-lined nest under an inconspicuous little heap will do just as well now the weather is finer, so setting to work she soon has all in readiness. Soft grass and shredded leaves line the nursery, and here her young are born. They are naked pink babies, and may number from two up to seven or eight, but four or five is the usual number. They grow very fast, a grey tinge about the body foretelling their velvety coat. In a few weeks' time this is fully grown, when, being now quite active, they are able to wander out into their dark world after their mother.

Even the colouring of the mole is probably connected with the underground life it leads, for nearly all the smaller animals that live above ground are some shade of brown, that hue being the least noticeable when a creature is running about in the shadowy spaces between the low growing plants and grasses. Now black is too noticeable for an animal that has to face the light of day, but of course makes no difference to one hidden underground. Strictly speaking a live mole is not black; it is a beautiful sheeny dark grey, rippling and 162 
changing in tint as the creature moves. Sometimes cream moles are caught by molecatchers, this variety being a lovely orange beneath, and where one has been taken others are likely to be met with. It is a curious fact that though most white animals have pink eyes, that is to say are albinos, this is hardly ever the case with the mole. Certainly it has not been so with all the cream-coloured moles I have met with. I have examined their tiny eyes under a microscope, when it was plain that they were dark. Pink eyes are caused by absence of all colouring matter from the eyes, the red tinge coming from the blood. Other freakishly coloured moles that I have seen are buff, 'smoked,' i.e. white with black tips to the hairs, and very pale grey. Piebalds are exceedingly rare, but there is a very quaint one in the great Natural History Museum at South Kensington, which is spotted, like a roly-poly suet pudding with currants in it! Of course all these varieties are mere freaks, and it is not one mole in many thousands that differs from its fellows. Indeed one mole is not only exactly like its fellow, but there is no difference whatever between the moles of England and those of the rest of Europe. 


\section{WILD CREATURES OF GARDEN AND HEDGEROW}

Though moles may not differ much in shape and make from one another, I found that they did differ in character and ways to a remarkable extent. Of the half-dozen moles which I have kept in cages so as to learn all I could of their habits, no two behaved just the same. The males were much bolder and easier to tame than the females, the latter being of a shy retiring disposition. The former would soon learn that a tap on the glass side meant food at hand, but the ladies would take several days before they would come to meet the hand that dropped in their worms. Once a gentleman mole had got accustomed to the noises made by people walking about the room it took a great deal to frighten him; but one of my females remained terrified to the end, always burying herself when anything moved. When watching a mole you would never think that it was blind, for its keen nose tells it exactly what is before it. For instance, I put a mole on a table from which there was a drop of three feet to the ground, but the mole did not tumble off. It raced to the edge, thrust its nose over, and drew back instantly as if it saw what a fall it might have. Then it ran across to the other side, where it did the same thing. It was 164 
quite difficult to realise that the animal was being influenced solely by the sense of smell !

As people sometimes speak in pitying tones of the 'poor blind mole,' I must point out here that the mole almost certainly leads a very enjoyable life, for it knows nothing of what light and sight mean. It has never lived above ground, it has no remembrance of things seen, it lives in a world of smells and scents of which we in our turn, with our blunted useless noses, can have no idea. In its dark tunnels it fights, hunts, feasts, mates, and enjoys life with quite as much gusto as the creatures of the light and air; it must enjoy its life, for the reason it is of all creatures one of the most perfectly adapted to its surroundings, so whatever you do don't despise the "poor little mole '; it does not want pity, and did it know anything of us would probably be sorry for people having to live up in the dazzling sunshine!

(Note.-The Moles constitute the sub-family Talpino, which ranges throughout the temperate parts of Europe and Asia, from England on the one side to Japan on the other. Four species are now recognised in Europe, but only one, $T$. europaca, the Common Mole, is widely distributed. It is plentiful on the Continent and throughout Great Britain, but is not found in Ireland.) 


\section{CHAPTER VIII}

\section{THIEVES OF THE NIGHT}

Wherever we go we meet with rats-town and country, stackyard, warehouse, and garden, it is all the same, they steal and rob anything and everything that is good to eat. Potatoes, grain, peas, beans, to say nothing of eggs, and even young chickens and ducklings, are seized, and in the latter cases murdered and eaten. Indeed, there is hardly anything that rats will not eat, and the damage done by them in the course of a year is simply appalling. Supposing that there is in this country one rat for every person, and there are certain to be many more-well, that would give us roughly forty million rats! Just think of all the good food they must waste in the course of a year ! Supposing each rat only eats a pennyworth, that would be forty million pennyworths each day, and as to what it would come to in twelve months, I think I will leave to any person who is fond of doing a sum to find out. 


\section{THIEVES OF THE NIGHT}

No wonder when rats do all this harm that nearly everybody hates and fears them, yet I have known rats which personally were very nice creatures. One of the most charming pets I have ever had-I have had a good many-was just an ordinary rat. An ordinary big grey rat from some farm buildings, and he was a big one too! His history was very strange. In April 1910 I had a pair of pet brown owls, for which I used to get all the rats and mice I could, as they were very fond of such food. One day a workman was getting some potatoes from the bury in the kitchen-garden, when he found hidden in the heap a rat's nest containing nine very small baby rats. Knowing that they were exactly what the owls would like he put the little things into a flower-pot, and the pot beside the harness-room grate, in which a fire was burning, to keep them alive and warm until they could be handed over to me to meet their fate. It was very warm by the fire, and I wonder they were not cooked alive, and Whiskers' history ended there and then; however, they were happy and kicking when I found them. What funny little mites they were; they might be 'only rats,' but still they were such wee helpless babies that it seemed 


\section{WILD CREATURES OF GARDEN AND HEDGEROW}

a shame to murder them, still, knowing what rats are, I hardened my heart and carried them off to the place where my owls lived. As I tumbled them out of the flower-pot on to the floor of the building a mad idea came to me. Our cat had just had kittens : would she rear a rat with them ? I must add that she had already brought up some rabbits, and another cat had mothered a fox-cub. No sooner had the idea occurred to me than I picked up the topmost of the nine, slipped it into my pocket, and hurried to the house, leaving the rest to their fate. The little rat I had saved was not only small, but blind, feeble, and had as yet but little hair on it, so anything more unlike a kitten it would have been impossible to have offered the cat.

I found puss with her kitten (the rest of her family having disappeared owing to orders from the head of the family given the day before) in her box in a cupboard in the kitchen. The remaining kitten was a roly-poly fat creature, with eyes just opening, and was about ten days old, and nothing could have been more unlike than the two little things. I could hardly hope that the cat would be so good, or shall I say so foolish, as to nurse such 168 


\section{THIEVES OF THE NIGHT}

an utterly different baby as the rat. However, I scratched her head and talked to her to take her attention, and slipped the baby rat down between her and the kitten so that it nestled up into her fur. Every moment I thought she would find out that something strange was beside her and turn round and eat it. The only hope was that she might not discover that it was there until it had got a nice 'kitteny' smell from lying with the kitten against her. Of course if it would take its food along with the kitten it would be safe, for no creature will hurt any young thing which has once sucked it. For ten minutes or more I sat beside them, then crept away leaving puss sound asleep with the new baby as well as her kitten nestled close beside her.

First thing the following morning found me downstairs, fully expecting to find that the rat had vanished; but no, there it was, safe and sound asleep in the box with the kitten, the old cat having gone out for a walk. By breakfast time she was back, and when I looked into the cupboard there were the rat and the kitten taking their food side by side. Hearing me the cat raised herself, purred, and began to wash the kitten, next she licked the rat all 


\section{WILD CREATURES OF GARDEN AND HEDGEROW}

over, after which she lay back and purred harder than ever, purring the contented song of a cat at peace with all the world. So she had adopted the newcomer, perhaps the strangest baby ever reared by a cat, for of all things a rat is the natural prey of her kind, and to make it more extraordinary this puss was a most sporting cat and particularly good with rats, having killed many. I must look forward a little bit here and say that though she killed many mice, and I regret to add rabbits, I never saw her bring home another rat. Henceforward ratting was done with. I wonder if she thought about the newcomer, whether, finding it so mysteriously beside her, she thought it was one of her missing kittens strangely changed that had come back. But whatever her opinions on the matter, the fact remained that she not only had no intention of hurting the little rat, but had completely adopted it, and not only allowed it to suckle, but treated it in every way as a kitten. For some days I watched the queer family carefully, being fearful that in some way the strange baby might remind her that he was really her natural prey, but no accident happened; both rat and kitten grew and flourished, and old mother cat was 170 


\section{THIEVES OF THE NIGHT}

as proud of her sleek-coated, slim, black-eyed youngster as she was of that fluffy ball the kitten. As soon as they could toddle about the two began to play together, rolling backwards and forwards across the box, and then running round and round it. Presently they learnt to climb out of the box and run about the kitchen floor. One day I saw the old cat go after the rat, pick him up in her mouth, and carry him back. He squeaked, but it was no good-his foster-mother, gently but firmly, carried him home. Fearing some accident, that either strange dogs or cats might harm the young rat, I moved the family to an empty room upstairs, which they could have to themselves and where they were safe from harm.

Whiskers, or to give him his full name, Samuel Whiskers, was one of the tamest creatures I have ever known, being the only animal that I have met with, which would when frightened come to one for protection. Most of the pets I have had would run away when startled, but Whiskers at the sight of anything unusual used to race to me and hide in my coat or up my sleeve. As soon as he could cling with his little hand-like paws, he learnt to climb up my fingers and sit 
with perfect confidence on my hand. Indeed, it was not long before he rushed to the side of the box whenever he heard any sound and tried to jump up to get to me. When taken upstairs to the empty room, in which he was allowed to run about, he would race across the floor to meet me, spring on to my skirt, and haul himself up hand over hand. His favourite seat was on my shoulder, where he would ride all over the place and even out of doors, disappearing under my coat at the sight of a stranger or anything peculiar. Presently I would feel a heaving down my sleeve, and then Whiskers' sharp nose and twitching whiskers would come sniffing out at the wrist. By the time he was full grown he was more than a tight fit inside a sleeve-that is when the owner's arm was there as well-and the sensation as he wriggled his way up and down was decidedly curious! Perhaps his favourite hiding-place was beneath my coat, just in the middle of the shoulders, where he made a lump that looked as if I was becoming decidedly hunch-backed.

But I am getting on rather too fast, and must go back to the point where the cat and her two babies had been taken from the kitchen to 


\section{THIEVES OF THE NIGHT}

the empty room upstairs. Here Whiskers had the wildest games with Tom the kitten. They romped and raced all over the place, playing a sort of hide-and-seek together, and it was the most curious sight to see these two, that ought to have been bitter enemies, playing together with such perfect goodwill. Yet one day something did go wrong between them, for I found spots of blood on the floor. Had the kitten bitten Whiskers, or had Samuel bitten his playmate? I looked them both over carefully but could not find the slightest sign or trace of a wound, but being thoroughly frightened I then and there took the kitten away. Tom found a most excellent home, where he proved a good mouse-catcher, but I have never heard that he attempted to kill a rat.

The cat had now only Whiskers to look after, so she gave him more attention than ever. This was evidently, from the rat's point of view, rather a mixed blessing, for she insisted on washing him so often. From the moment he was old enough to sit up on his hind legs, Whiskers had been most particular about his toilet, often sitting up and washing his face and body; but his adopted mother had no 
opinion of his efforts, and persisted in washing him all over herself. She evidently did not think he was to be trusted to do it properly. She would hold him down with her paws, paying no attention to his unhappy squeaks, and lick him all over. He seemed to hate her washings, but, like the boy in the hands of the old woman in the Pears' Soap advertisement, he had to have it. When she let him go he always went over the work again. He was really a very clean creature, though he did neglect one part of his body, and that was the tail. Except once when quite small I never saw him lick his tail, though I watched him wash himself many scores of times. It is a curious but noticeable point that the tails of wild rats are often very dirty, even being coated with mud and filth, so I think it cannot be their custom to clean this useful member.

Mentioning his tail reminds me of the one and only time that Samuel forgot his most excellent manners. He had been sitting at an open window, when my brother stepped forward to shut it. As it was drawn down the rat turned round, whisking his tail under the falling frame. The heavy window slammed down on it, nearly cutting it off, and Whiskers 174 


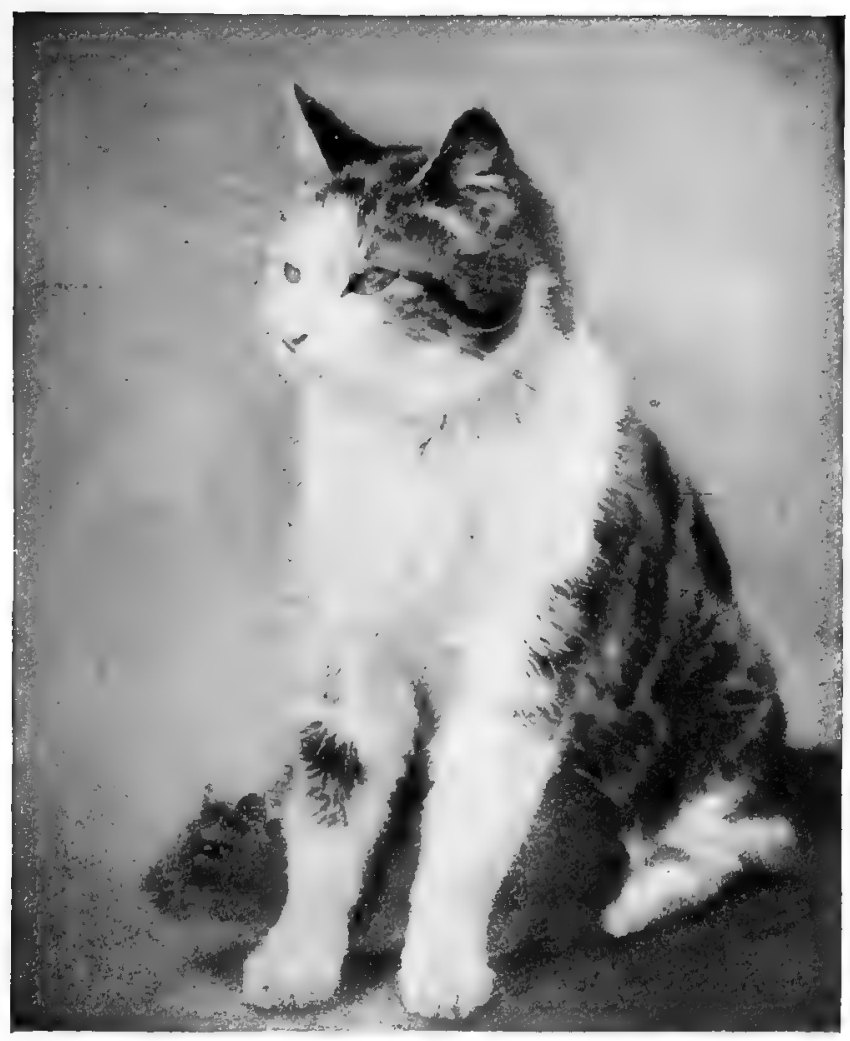

'WHISKERS' AND 'OTD PUSS' 

in his fright and pain bit the thing nearest to him, which happened to be my brother's hand. His tail soon mended, and that was his one and only lapse from perfect gentleness and good behaviour. Sometimes he was sorely tested, for I have dragged him from behind furniture, or out of his nest, by a leg, the scruff of his neck, or the first part that came handy, but he never resented my rough treatment and took it all in good part. I am speaking of not only when he was a sleek halfgrown youngster, but when he was a fullgrown exceedingly big buck rat.

Puss by no means considered her duties finished when she had washed her rat, but went poaching and mousing on his behalf. If a cat was heard crying very piteously about the house we knew at once that it was old puss, who had come in with something for the rat, and was mewing for some one to go and open the door so that she could take her kill to his room. Proudly she would bear the young rabbit or mouse into the room, drop it, and lie down purring contentedly, while Whiskers sniffed at the corpse. But further than this, excepting on one occasion, he never got, as I always took it away. Once he did carry the 
body of a mouse into his sleeping box, and as rats in a wild state are by no means averse to flesh, eating carrion greedily, slaying young ducks, chickens, and even frogs and toads, I think if he had had the chance he would probably have eaten it. However, I did not give him the chance to try mouse meat, but took it too away.

As time went on and another family came to take the cat's attention, she did not bother so much about Whiskers, but she never forgot him, was always on friendly terms, and often paid him a visit. He would rush to meet her most excitedly, and it was indeed a strange sight to see that big rat sniffing noses with the tabby-and-white cat. Once when Samuel was loose in the sitting-room another cat was accidentally let into the room. The rat, thinking it was his foster-mother, ran to meet her. At which the cat with a startled spit stepped back. On came Whiskers, the cat's fur rose, her tail fluffed out, for a moment she hissed and spit, then her nerve failed altogether, and she bolted for all she was worth! Fancy a rat which instead of running away from you came straight at you! It was too much for her, and she was not seen for some time after. 


\section{THIEVES OF THE NIGHT}

But this cat was not the only individual upset by the rat, for many people objected to him. I have seen men, who would have faced and stopped a runaway horse without a tremor, go hot and cold if Whiskers ran across the table towards them. I always told strangers that he was not only perfectly harmless but a very gentle amiable creature, but such is the general fear of and dislike to rats that hardly anybody could be persuaded to touch him. 'How could I handle and play with such a horrid animal ?' was the usual question. It was in vain to explain that to me he was neither repulsive nor horrible. One farmer who came into the house, and saw for the first time the rat peep out of my sleeve, looked as if he would have liked to have jumped on to a chair out of Whiskers' way: 'For heaven's sake, don't let the brute come near me, Miss,' he said, 'or I 'll brain him!' And I am sure he meant it!

Yet it only shows what a difference a little knowledge makes, for all the family who knew him well were exceedingly fond of the rat, despite the mischief he sometimes got into. For instance, my father made a great pet of him. He would let him sit inside his jacket 
in an evening. One night when the rat had been quiet for some time my father remarked, ' I don't know what he is doing, but I can feel him pulling at something.' We found he had been amusing himself biting the straps off my father's waistcoat! He was never quiet unless in mischief, but always racing about, hauling himself up the curtains hand over hand, to run along the curtain poles, from which he would slide down the curtains on to the ground once more. Then he would scamper to and fro, climb on to somebody's knee, very likely jumping from there to the table, where there was generally some food put ready together with a glass of water. He was a thirsty animal and drank a good deal. It was a funny sight to see him with fore paws-so like little hands-on the edge of the tumbler, and his tongue lapping so fast that one could hardly see it going up and down. Next he would pick up a walnut, and, holding it with his hands, nibble away at it. When he had eaten all he wanted, he would carry off any food that was left lying about to a hiding-place behind the bookcase. Small stuff, such as grain, he carried in his cheeks, stuffing his mouth with it until he looked as if he had a swollen face, 178 


\section{THIEVES OF THE NIGHT}

but big bits had to be carried as a dog carries a bone. He would hurry backwards and forwards until he had carried all the food off, after which he would amuse himself by making a nest behind the bookcase. As the housemaid brushed his nest away every morning when doing the room, a fresh nest was begun each evening, but he never seemed to get tired of the entertainment. He would take away any loose things that he could find, especially papers, and the newspapers when dropped on the floor would often begin to rustle and move in a mysterious way. What happened was that Whiskers got underneath the sheets, took hold of one corner, and towed the whole off to his favourite hiding-place, there, unless it was at once pulled out, to tear it to bits.

The nest in Whiskers' sleeping box was a jumble of paper, straw, feathers, and odds and ends of rags. Sometimes it had to be burnt, but he never seemed happy with a nice clean bed of hay or straw, and immediately set to work to collect more odds and ends.

Samuel Whiskers was very fond of being petted, and would lie on my lap, or sit on my shoulder, as long as I would go on stroking and petting him, but the minute one 
stopped he was off again. He usually came when called by name, but was shy if there were strangers in the room, for he knew all the family perfectly well. He was also tiresome to catch whenever he thought he was to be returned to his own quarters, for he would do anything rather than be caught and shut up, yet once you got a grip of his slippery form he would give in and not try to get away any more. But how different it was when I went into the room where he was kept; then his one idea was to reach my shoulder as quickly as he could climb there.

Twice before the final disaster we thought we had lost him, each time he got up a chimney, but came down again when called. The third time he not only got out of his room but out of the house, and nothing was heard or seen of him for a week. At the end of the week I noticed a dog pointing excitedly, after the manner of terriers when they have found a rat, at an old disused chimney in an outbuilding. Knowing how fond Whiskers had been of chimneys I drove the dog away, and, going down on my hands and knees before the dirty old grate, I called the rat by name, then listened. Surely there was something stirring ? 


\section{THIEVES OF THE NIGHT}

Again calling, and listening once more, I felt sure there was something moving, so turning back my sleeve I put my arm up the dirty, sooty, old chimney; instantly small feet clasped my arm, and a moment later my rat was in my hands. Oh! poor Whiskers! He was black with soot, he was half-starved and very thin, his fur which had been smooth was harsh and staring, and he was covered with bites from head to foot. What a battle he must have had with some wild rat. I only hope that he killed his enemy, for it practically killed him, as he never got over his adventures. He never recovered his old sleek look; he got weaker and weaker, until at last all he cared for was to lie and be petted. We got all sorts of good things for him, but it was all vain, and he died two months later, when he was just two years old. Poor old Whiskers, a more affectionate and intelligent creature no one could have wished to meet with, and, whatever the sins and robberies of his kind, he was entirely lovable.

I have said that Whiskers was just a common rat, the kind that in books is called by various names, such as the grey, brown, Norwegian, or Hanoverian rat. The reason of the two latter 
names is that once there were no brown rats in England; they came here on ships, some people said on the ship that brought over George I. (but that is almost certainly not true, for the brown rats must have arrived before that), and so they called them Hanoverian rats. Other persons said that they came from Norway, so they named them the Norwegian rats. And yet others noticing the colour, and comparing them with the rats which were common before the brown rats came, called them either 'grey rats ' or 'brown rats.' This was by contrast with the pretty little rat, generally black in colour, which was our common rat in the days before the brown rat turned up in this country. In the first place there were no rats here at all! What a pity they ever came!

Previous to the time of the Crusaders there were no rats of any kind to run about our houses and buildings and raid our stores, gardens, and poultry-houses. They are not mentioned in old writings, their bones are not among the rubbish where other bones are found in old buildings, and in the Welsh language there is not even a word for rat,when the Welsh wish to speak of a rat they use words the equivalent of "French" or 'foreign 182 


\section{THIEVES OF THE NIGHT}

mouse.' 1 When the Crusaders went to the Holy Land they met with plenty of rats. Not big coarse rats like our present common brown rat, but smaller, slim, smooth-coated, elegant rats, with large ears and big black eyes, so that they were more like large mice than anything else. Linnæus, the great Swedish naturalist, saw this likeness, for he named this kind of rat Mus rattus or the ' mouse rat.' When the ships returned to England from the Holy Land there can be no question that many of these rats got on board, and were in this way brought home. ${ }^{2}$ At the present time there are often more ' Old English' or 'black' rats on board ships than any other kind. Once landed in this country, they increased and spread from one end of it to the other, and, being quick, active creatures, were not content to stop in the outbuildings, cellars, and basements, but went all over the houses. The nuisance they must have been we can hardly imagine in these days when people are not often bothered by rats in houses. What it must have meant can be gathered from the damage that was done by two which got loose at my home. After a great

1 Barrett-Hamilton's British Mammals, p. 579. ${ }^{2}$ Ibid., p. 582. 
deal of trouble-for the Old English rat is by no means often met with in England nowadays -I got some specimens from a seaport. They were most interesting animals, but had one terribly tiresome habit, and that was of gnawing their way out of their cage. Though kept in an outbuilding, two managed to get into the house, which they ransacked from top to bottom. They found secret ways inside the walls, raided the cupboards and store-places, and generally got into more mischief than any one would believe, before I succeeded in catching them up again. Fancy what it must have meant in the old days when the houses were chiefly built of wood and rats could make their way anywhere. It was not only a question of the actual mischief done by the rats, but the terrible disease that they helped to carry about. It is now known that rats, both 'brown' and 'black,' can have the awful ' bubonic plague,' which in bygone times was a pestilence that often swept not only over the Continent but also across these Islands. The 'Black Death' the people called it. They died in hundreds, whole families being exterminated in a few days ; no one, whether prince or beggar, was safe, and young and old, rich and poor, 184 


\section{THIEVES OF THE NIGHT}

died together. They never knew who would go next, nor in which house the dreaded pestilence would appear. Sometimes it would sweep down one side of a street and leave the other, then it would visit one house and miss the next. Only of late years have men of science, working in India and other Eastern countries where plague still kills thousands annually, been able to explain it. They have found out that rats were at the bottom of all the trouble. Not only do rats get plague as badly as people, but it is entirely by means of their fleas that the bubonic plague is spread. All rats have fleas, and when one dies they leave the body as soon as it begins to grow cold, making for the nearest living creature, often a human being. Now in the case of a plague-stricken rat, the fleas, which have been sucking its blood, ${ }^{1}$ carry with them the germs of the disease, and when they bite their new host the awful germs of death pass into his blood, where they multiply, and quickly cause a fatal result.

We can now understand how it was that in the days when the Black Death raged across

1 'At one meal a single flea can take as many as 5000 plague germs into its stomach. - - Rats and Mice as Enemies of Mankind, by M. A. C. Hinton, 1918. 
England it spread so curiously, for of course where the disease appeared depended chiefly on which houses were infested with rats and which were not. At that time rats had a much better chance of spreading the disease than they have now, for the town houses were chiefly wooden ones into which the rats could make their way with very little trouble. Besides, the 'black' or 'Old English' rat was much more of a house rat than our too common brown rat is. It was a better climber, and a more active mouse-like creature than the latter. Moreover, people were not so particular in those times as we are now; they accepted rats in the house as a matter of course, and a few fleas did not worry them. In early times it was dirt, not cleanliness, which was 'next to godliness'; too much washing was not the fashion in any class of life, so no wonder the plague had every chance of spreading, for they little dreamt that it was the rats which scampered about so merrily that were the bearers of disease and death.

But the black rat's good time in this country did not last for ever. Just as it had come from the East, so in the middle of the eighteenth century there appeared in Europe, and soon 

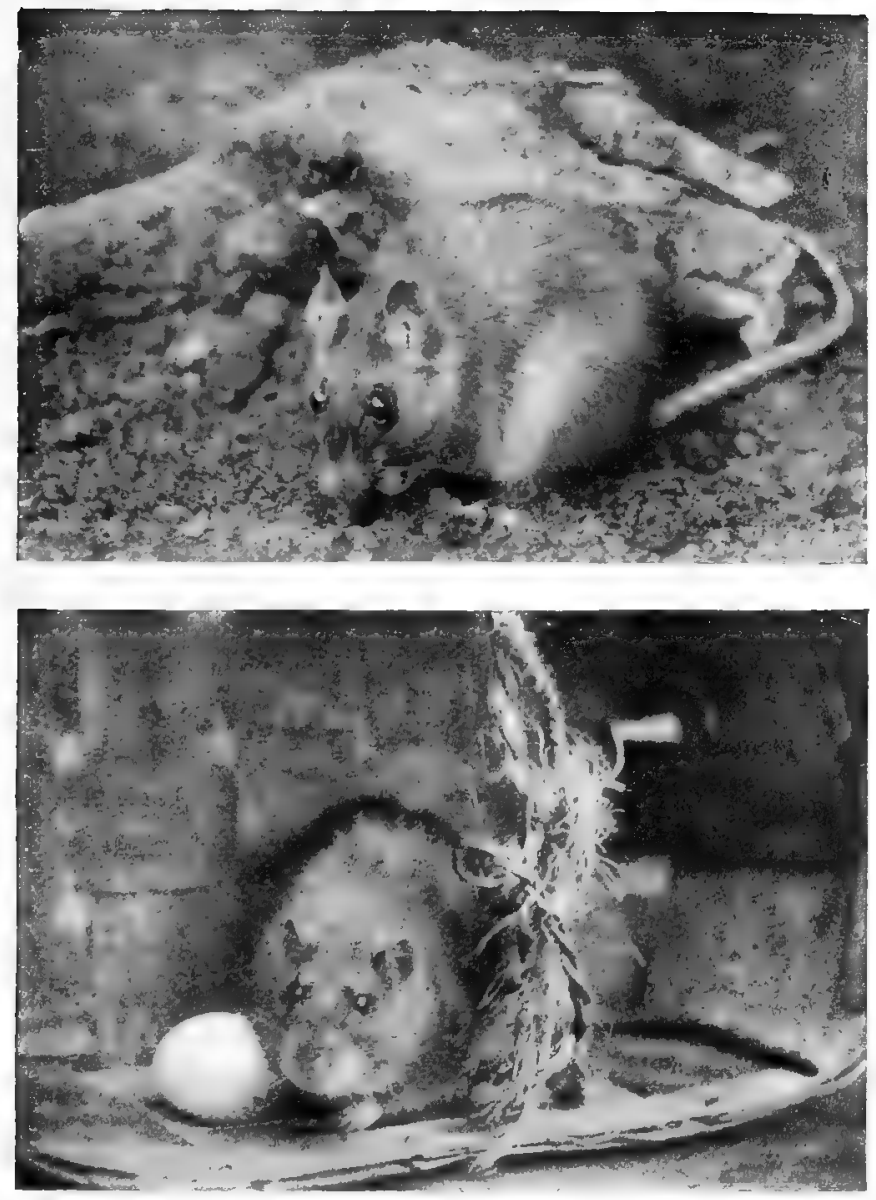

THIEVES OF THE NIGHT

No. I. An old English Black Rat busy eating

No. a. A Common Brown Rat with a hen's esg 



\section{THIEVES OF THE NIGHT}

came on here, a bigger and stronger rat, the common brown rat of the present day. The newcomer was not only bigger and more powerful, but was more savage and bloodthirsty. By one means and another it pushed out the old black rats and took their places; it killed their young ones whenever it came across them, it took possession of all the best food supplies, so that in a short time the Old English rat, from being a common everyday creature found in every house and garden, had become quite rare. At the present time it is only found in a few seaports, where its numbers are kept up by fresh arrivals from the ships, for it is still the most common kind on board boats.

With the arrival of the brown rat the dreadful plague ceased to sweep across the country as it used to do; for one thing houses were now better built, but for another the new kind of rat was not so fond of getting into them. We all know to our cost that rats like to be about buildings, how they thieve and steal all they can, but the brown rat is not the house thief that the black one was. I have already mentioned how two of my tame black rats when they escaped from their cage at once managed 
to get into the house, in which rats had never appeared before, and made their way from top to bottom before I was able to catch them again. Of course, the brown rat can also have and spread the plague by means of its fleas, but owing to its habits it is not nearly such a danger as the older kind used to be.

It is really rather a mistake to call the common rat the brown rat, though this is the name generally used, for it is sometimes black in colour, nor is the name black rat a good one for the other kind, as 'black' rats are very often fawn in colour. Indeed none of the everyday names of these rats are descriptive, for the black rat, though older in England than the brown, does not, considering that it was a foreigner that came here in historical times, deserve to be called the Old English rat. Neither was the brown rat a native of Norway or Hanover, so what is the use of calling it the Norwegian or Hanoverian rat ?

Whatever their colouring, the two kinds can generally be told apart in the following way: in the case of the brown rat the tail is not quite so long as its head and body, and in the black rat it is considerably longer. The ears of the black rat are large in proportion to its head; 188 


\section{THIEVES OF THE NIGHT}

its eyes too are very big, looking, when it is nervous, as if they would jump out of its head; besides which it is a slimmer, more mouse-like creature than the common brown rat, and as a rule is much smaller. Some people think that the tame black-and-white rats that are kept in cages belong to this kind, but I believe it is never so, and that pet rats are always of the common species-at any rate all the piebald rats $I$ have seen have been of the latter kind. The tame black rats that I had were very pretty, interesting creatures, the little ones being especially dainty; but I never looked at them without thinking what a strange history lay behind those elegant, mouse-like rats. How once upon a time their ancestors had lived out in the wild desert, far from men, until some rat more go-ahead than its fellows had found out what good things were to be had by following the camps and hunting round the dwelling-places of mankind, so that they became pests that live only where there are people, and have passed with human beings from their home in Central Asia to the farthermost corners of the world; and how another rat of the Eastern deserts, our present common rat, found out the same thing, and not only 
took to robbing people for a livelihood, but spread even farther than its cousin the black rat, and in many countries drove its forerunner completely away! So any evening when you are out in the garden or by the poultry pens, and see one of these thieves of the night scamper off, remember how it is that the scoundrel comes to be there, and that he is not one of our truly native creatures, like the field mice, blackbirds, thrushes, robins, and wrens, but an invader from over the seas, who has nothing to recommend him except the cleverness with which he raids and robs. When all is said and done, the common brown rat is one of the most intelligent of animals, for it is to his wits that he owes his great success in the battle for existence, in which he has not only wild animal foes to fight, but we people out of whom he gets his living. So, however big a scoundrel he may be, I must close this account of rats by paying my respects to the cunning, unscrupulous, and most successful brown rat.

(The Brown Rat until comparatively recently has been known to science as Mus decumanus or norvegicus, but in Miller's Catalogue of the Mammals of Western Europe (British Museum, N.H., 1912) it becomes Epimys norvegicus. The Black Rat, the Mus rattus 190 


\section{THIEVES OF THE NIGHT}

of Linnæus, is also placed in the genus Epimys, becoming $E$. rattus. There are many forms and varieties of the Black Rat, but Miller only allows sub-specific rank to the fawn-coloured $E$. r. alexandrinus. Other authorities recognise several more sub-species.) 


\section{CHAPTER IX}

\section{SOME GARDEN BIRDS}

OF the many birds that make their home in the garden where I live, my favourites are the pied wagtails, that nest every spring among the creepers on the wall of the house. They are so smart in their black, white, and grey plumage, and flirt their long tails with such an impudent air, that I am never tired of watching them as they run to and fro on the lawn after the flies, now springing up into the air, then running quickly across the grass, and all the time the picture of dainty life and grace. Each spring they come back, and are soon busy gathering odds and ends of dried grass suitable for nest-making, together with feathers to make a soft lining for the treasures that the nest will presently hold. Though bold and in some ways cheeky little birds, they are also cautious, and neither cock nor hen ventures near the nest while they think that you are watching them. They will 192 
run backwards and forwards on the lawn, each with his or her beak full of material, waiting until you are out of sight, when, if you peep round a corner, you will see them flying up to the nest, the whereabouts of which they were so anxious to keep to themselves. For sixteen years running pied wagtails have built their nest on the house, and as the present owners of the nesting site can hardly be the original pair-for small birds, though undoubtedly living longer than they are generally supposed to, can hardly be credited with reaching the age of sixteen or seventeen years-the question arises as to whether they are the young of the first ones. Or is the matter arranged, when any accident happens to one of the pair, by the survivor bringing home another mate ? I cannot say; all I know is that every spring the wagtails come home to their old nesting site, and, not content with one family, generally build a second nest after getting rid of their first brood, and launch a another lot of nestlings into the world.

I think one of the prettiest sights I have ever watched, was when I had put up a small hiding tent in front of a pied wagtail's nest, for the purpose of photographing the old ones 


\section{WILD CREATURES OF GARDEN AND HEDGEROW}

feeding the youngsters, and saw the family launch themselves into the wide world. The nest was not that of my friends which build in the creepers on the house, for they make their home too high up for photography, but of another pair that had chosen a hole in an old wall belonging to some farm buildings. The parents had got quite used to my tent, and took no notice whatever when I was inside with my camera, but went backwards and forwards with food for the hungry family. In forty-five minutes they visited the nest nine times, or on an average once every five minutes. Say they began work at five o'clock (probably their hungry nestlings were begging for food long before that), and continued up to nine at night, which would mean a sixteen hour working day, they would between them go backwards and forwards one hundred and ninety-two times. As a rule birds that have young to feed slacken work a little at mid-day, but this is their only rest; they otherwise slave unceasingly to supply the everlastingly hungry mites, and it is not only the question of going to and fro, but of searching for the insects in between. But then in the wild world there are no trade unions, no strikes, no eight hours day, and no 194, 
stopping work to do as you like, for the simple reason that those creatures which will not work, and work hard, soon cease to exist! It is only by steady hunting for insects that families can be reared and sent out into the jworld.

I have mentioned that I saw these young wagtails start upon the great adventure-it was early in the morning-7.15 to be exact -when I went to the nest, and found one or two of the nestlings had already flown, while the rest were on the point of following them. Hastily hiding in the little tent and bringing the camera to bear on the nest, I waited events. The morning sun struck warmly on the wall, and the youngsters, anxious to be off, yet fearful of leaving, kept hopping out of the shadowy hole wherein was hidden the nest, standing for a moment or two in the light, and then hopping back to its shelter. What dainty little birds they were in their pearlgrey plumage, which is quite unlike that of the old birds. They wear this uniform until the autumn, then moult it and assume the black and white dress. At last one of them, gathering courage, spread its little wings and flew, awkwardly and feebly it is true, to the top of my tent, where I could hear it pattering about 
overhead. Soon another joined it, and hopped to and fro. Presently they went away, but hardly had they flown than the old wagtail appeared at the nest with a beakful of grubs. Never have I seen such an astonished and 'taken aback' look on any creature's face, as appeared on that of the old bird when she found all her family had gone. She looked into the hole to be sure she was not making a mistake, then flew off to search for the missing young ones, and I have no doubt that she found them near the stack-yard pool, for it was there that I saw the wagtail party a few hours later, running to and fro on the muddy margin, the old ones catching the numerous flies to be had by the water, and the young ones following them and receiving the flies as quickly as they were caught. In a few days those young ones would be able to look after and feed themselves, whereupon their parents would begin another nest, for it is wagtail custom to rear two broods in the season. The question is what happens to all the young ones, for, notwithstanding that each pair of old birds usually manages to bring up and get off two families of five apiece each spring, the number of pied wagtails in the country gets neither 196 
more nor less. Of course accidents happen, and many youngsters come to untimely ends soon after leaving the nest: then there is the autumn migration, when many more get lost. A few wagtails stop with us throughout the winter, but the greater number go south, crossing the English Channel, and making for the Mediterranean region. That pied wagtails seen in Portugal and the south of France during the winter, are the same birds that were in England for the spring and summer, has been proved by putting small rings on the legs of nestlings. A wagtail thus marked at Cheadle in Staffordshire was taken the winter following the spring in which it was ringed in Portugal. ${ }^{1}$ But for being captured this bird would almost certainly have come home the next March not only to England, and one particular county, but to the very spot where it was born and bred! We may well wonder how birds find their way!

Yet the weest of birds manage these long journeys. Take, for instance, the little willow warbler, or willow wren, that tiny atom of grey-green feathers, which every April comes

1 Ringed at Cheadle, Staffordshire, by Mr. J. R. B. Masefield, 18th June 1915, and recovered at Vieira de Leiria, Portugal, in January 1916. See British Birds, vol. x. p. 61. 


\section{WILD CREATURES OF GARDEN AND HEDGEROW}

to us. with the rest of the migratory birds. This tiny dainty sprite in bird's feathers wings its way across the seas, with the rest of the travellers, and when its song is heard in the budding hedgerows, when we see it slipping in and out of the bushes in the garden, we know that the spring is really here, and that the cuckoo, if not already arrived, will not be long behind his fellow wanderer.

Once it has reached home (for I call the spot where a bird makes its nest and rears its young its home, not the country where it winters) the little warbler does not waste time, but finding a mate as quickly as possible, or maybe joining forces with its old mate, for it is astonishing how many birds pair for life, begins the important business of the spring without delay. With bits of grass and hay a domed nest is built on the ground, beneath a tuft of grass in the corner of the garden, by the orchard fence, or anywhere else where there is shelter. It is well and warmly lined with feathers, on which soft quilt are presently laid seven or even eight tiny white eggs spotted with pale brown or pink specks. They are the most lovely of small eggs, the shells being so transparent and delicate that the yolks are seen 


\section{SOME GARDEN BIRDS}

through them and give the eggs a pinky warm shade impossible to describe.

One spring I found a clutch of these beautiful wee eggs in their domed nest on the bank of the kitchen-garden hedge, so quickly had the bird photography tent up, and, as soon as the birds had got accustomed to it, tried to take some photographs of them. They did not mind in the least the noise of my shutter going off, nor did the rattle of a slide being closed bother them a bit. I took one picture of the hen going into the nest, and then could not get her to come out again until I left the tent, and even when she saw me step into the open she was not really frightened or in any hurry to leave her precious eggs. Indeed they were a most charming and confiding pair, and once the young ones were hatched they went backwards and forwards with food without any regard whatever to any noises I might make in my hiding-place. They worked as hard as my wagtail friends, if not harder, for whereas the wagtails had had but five young they had seven to provide for. It was chiefly small green caterpillars that were brought, and gave one some idea of the great good that is done by these small insect-eating 
birds, for the number destroyed by this. one pair must have been enormous, and as the willow wren is a very common bird it must kill millions of harmful grubs in the course of the summer. What a twittering there was from the youngsters each time one of the old birds returned with a beakful of these little caterpillars, but neither parent ever hurried himself or herself, carefully and deliberately a fair share of the good things was pushed down the throats of certain of the nestlings. As they all appeared equally well-fed and looked after, I suppose the old birds took care that those missed at one visit should be fed first at the next, though how they told one from another, or knew which they had fed last, was a complete puzzle to a mere human. The meal over, the little ones would sink back into the nest, while the parent remained for a moment in the entrance hole waiting to see if any of them wanted attention. The nest was kept beautifully clean, everything being carried away by the old birds. They never got soiled when doing this, as the excreta of all nestlings whose parents look after them in this respect is covered with a slimy non-adhesive coating, that enables it 200 
to be handled, or rather to be taken in the beak, without any fear of being messed by it: It is all carried to a distance and then dropped, so that there shall not be anything to betray the spot where the nest is hidden. Very well hidden, too, was this particular willow wren's nest, being placed on a hedge bank among ivy and grass. The roof of grass not only hid the eggs from view, but was so like a heap of odds and ends of dry stuff that even if you had caught sight of it you would never have thought of it being a nest. Why this bird should take such trouble to weave a dome over its nest while other ground-building birds like the robin are contented with an open cup, is a question that has often puzzled me. Of course the robin generally builds in a hole in a bank, and the willow wren builds on the ground, hardly ever choosing a recess, yet there are plenty of other kinds of birds, such as the skylark, that make an open nest with no cover out in the middle of a meadow. Personally, I think the willow wren's domed nest is to keep the sun off the young birds, which are greatly distressed by heat. One sultry morning the nestlings in question could be seen lying with necks outstretched panting and 


\section{WILD CREATURES OF GARDEN AND HEDGEROW}

gasping, yet the sun was not shining directly on the nest. It is almost certainly the wish for shade and coolness that makes so many birds build in dark evergreen trees, such as fir and yews. But however hot they were, the young willow warblers never lost their appetites. They knew that the old one was coming with food long before she or he got near the nest; their heads would shoot up, their beaks being opened wide, and I had a view of seven gaping throats quivering backwards and forwards in eager expectation. If anything caused the parent to turn back, they would sink disappointedly down again, only to thrust their heads towards the entrance when a twig or a leaf rustled again a moment or two later.

Day after day I watched all these happy home arrangements. I saw the little mother brooding, feeding and caring for her nestlings, and the father's fond anxiety; how he helped with all the duties, and how the pair twittered and scolded when any person came by, trying to take their attention and draw them from the spot where the nest was hidden. Cats in particular worried them dreadfully, and, as it turned out, their fear was not without ground. 202 


\section{SOME GARDEN BIRDS}

The nestlings had grown very fast, they were already well clad with feathers, and another day or perhaps two would have seen them launched into the world, but the next morning, when I went to look and see if they would get away that day, I was horrified to find, in the place of the neat ball of woven grass tucked down among the plants that grew on the bank, a handful of rubbish strewn on the ground. The tragedy was apparent at a glance; the nest had been torn to pieces and the young birds were gone. There could be little question but that a cat had eaten them. I greatly fear that it was my old pet cat who was responsible for the crime, but in the absence of direct evidence it could not be brought home to her; all the same I did not feel at all pleased with her for many a day afterwards.

The poor little parents could not have wasted much time grieving over their loss, for within a very short time I found another willow wren's nest near the old spot. This family was reared in safety, and before they left the nest I put tiny rings on their legs so that if ever $\mathbf{I}$ met them again I should know them. They were about the kitchen garden for a little while, eating the green saw-fly grubs from the 


\section{WILD CREATURES OF GARDEN AND HEDGEROW}

gooseberry bushes, and hunting the rows of peas from end to end, but the autumn was coming, so one day they vanished, no doubt to travel south with other birds, to places where the winter is mild enough for little insect-eating birds to live in comfort. We may well wonder how such tiny creatures manage not only to fly for such long distances, but to find their ways. In many cases, for instance that of the cuckoo, the old birds leave for the Continent a month or more before the young ones, so there cannot be any question of the youngsters being shown the way by their parents. Some people say that the birds simply drift south before the cold northerly winds, which may certainly have something to do with it, but not everything, for on the return migration in the spring birds often arrive in the teeth of a north-easterly wind. The usual answer, that the whole thing is a matter of instinct, really is no answer at all, for we want to know how instinct works and how it tells the birds what to do and which way to go! The untaught knowledge that so many birds have, of how to find their way across hundreds of miles of sea and land, is one of the most marvellous of the many marvellous things in 204 
Nature, and one about which there is yet a great deal to be learnt.

Though so many birds migrate regularly, other kinds are practically stationary all the year round; the different tits, for example, do not travel far as a rule. They are much attached to their home districts, and no birds keep so strictly to the one nesting place. Year after year you will find a pair of tits nesting in the same hole in some tree or wall. I know of an apple-tree with a hole in a bough wherein a pair of blue tits have nested every spring as long as I can remember; then there are a pair of coal tits (coal tits are those black-headed tits with a white patch on the nape of the neck) which, year after year, have bred in a certain hole in an old yew-tree; and the handsome great tits, a pair of which nested for eight or nine seasons in the kitchen-garden wall, only to return one spring and find that their hole had been stopped up with mortar when the wall was repaired the autumn before. Another pair of great tits have for years made their home in a disused pump in the backyard. At one time when the pump was in daily use they tried in vain to get a nest made in it. Quantities of moss and rubbish were thrown 


\section{WILD CREATURES OF GARDEN AND HEDGEROW}

out daily with the water, but still they persevered and, entering by the hole over the handle, dropped their loads of building material down the shaft. How the people who went for water grumbled at the mess that the birds had made! They had no sympathy whatever for the little creatures that pushed odds and ends of moss, grass, and fir needles so untiringly down into the shaft. However, all things come to those who try long enough, and one day the pump got out of order, water would not come, and, as another and better supply was at hand, the old pump was allowed to stand idle and unrepaired. The following spring the tits got to work without delay; they stuffed the top of the pump full of bits of grass and hay, then they were seen bringing moss to make the cup, and lastly quantities of soft warm rabbit's wool to line it with. By standing on the pump trough and lifting up the top of the pump, one could see how they were getting on. It was astonishing what good progress they made, and how soon the nest was ready for eggs. Then there came a morning when a delicate pinky-white egg spotted with small red specks was found nearly hidden in the rabbit's wool lining. It is a point worth noting that the 206 


\section{SOME GARDEN BIRDS}

first few eggs laid are invariably covered up with a nice quilt of wool, so that one cannot at first glance see how many there are. The old bird begins to sit before the clutch is complete, when the fourth or fifth egg is laid, another three or four being added afterwards, seven to nine being the complete set. The result is that one or two of the little birds are rather behind the rest of the family in hatching, and there is often, as in a large family of young pigs, a 'harkner' or little one. The parent great tit is a bold little bird; she believes in trying to bluff her foes, so if disturbed when sitting makes a hissing noise and bounces up and down in her hole. The first time my friend in the pump did it she fairly startled me, and I can well believe that the hissing and noise would frighten away any intruding mouse, starling, or other bird or beast that might try and interfere. Starlings are a great nuisance to the rest of the birds that make their nests in holes, for they are quite without conscience, and if the entrance to a hole is big enough for them to get inside, will not hesitate to bundle out the occupiers' eggs and take possession of the place. Before now $I$ have found the eggs of 
the first comers lying broken on the ground and the unscrupulous starlings rearranging and adding to the nest to suit themselves. However, the hissing noise must be startling for such intruders. It is curious what a number of creatures make a snake-like hiss when they want to bluff animals bigger than themselves out of attacking. Take the sitting wild duck, the domestic cat, and the ferret as examples. These widely separated creatures all hiss and spit when they want to intimidate an enemy. For its size not one puts up a better bluff than the great tit, unless it is its smaller relation the blue tit, which can also make a most effective hiss. Even when one knows what to expect, you cannot help starting at such a strange noise coming from a mere bird, and anybody not knowing would, I am sure, have thought there was a snake down our yard pump whenever the great tit made this noise.

Before going on to tell about the young great tits it may be as well to say the great tit is the largest of our British tits, it is altogether a stronger, bigger, and longer-legged bird than any of the others; it is also a very smart creature in its blue-grey plumage, with 208 
wing bars, white cheeks, black top to its head, black throat, and the black extending down the front of its greeny yellow waistcoat. The black down the breast is broader and extends farther in the male, but otherwise the two sexes are much alike. During the nesting season both get shabby, and the hen is usually very worn in her feathers before she gets the young ones off ; indeed you would hardly know her for the smart tidy bird that came househunting in March. But the change is no matter for wonder, considering how hard she and her mate have to work from early morning to late at night, bringing caterpillars and other grubs in a vain endeavour to satisfy their ever hungry young. The little ones keep up an incessant squeaking, which rises higher every time the old birds go near the nest, only dying down for a moment after the food has been delivered. All caterpillars are carefully pinched and pecked to make sure they are dead before being brought to the nest. I have watched a bird take a fat green caterpillar under one foot, and peck and pull until not a wriggle was left in it, then take it in its beak and fly down to the pump. The constant attention of the parents has its reward, for the young grow 


\section{WILD CREATURES OF GARDEN AND HEDGEROW}

amazingly fast, and are soon clad in a smart uniform of feathers that puts their worn and shabby parents to shame. Soon they are scrambling up to the entrance hole and peeping out into the yard, after which it is only a matter of hours until they leave. The first flight is a critical time, for the cats, to say nothing of the tame raven that lives in the backyard, are all on the look out for tender young fledglings. If they manage to flutter across to the ivyclad wall, and from thence to the big Spanish chestnut tree, all will be well. The chattering and scolding of the old birds betrays how anxious they are, but once they get them into the trees they are fairly safe.

Unlike so many other birds, tits do not break up their family parties, but remain together all winter. In the autumn several lots will join forces; blue tits, coal tits, and great tits will flit twittering happily together through the trees, and what a pretty sight it is to watch them as they search here and there for hidden insects. A blue tit hangs upside down peeping into a curled and withered leaf that has not yet fallen from its place. A great tit having found a nut carries it to the trunk of a tree, drops it into a convenient crack in 210 


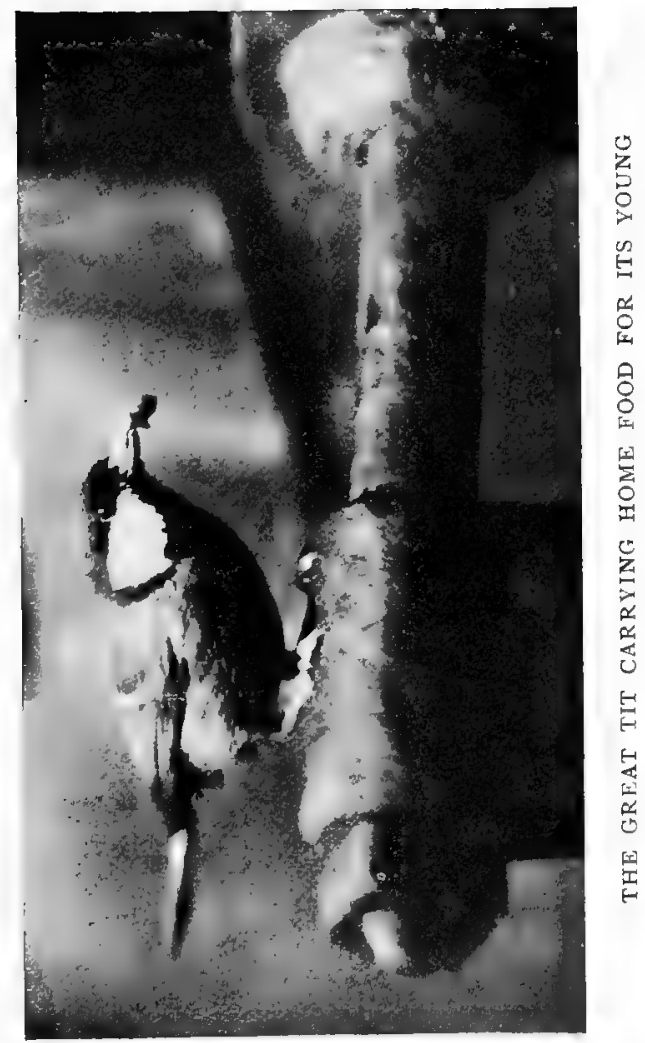



the bark, where, having got it firmly fixed, he proceeds to hammer it with his strong pointed beak. Soon he has drilled a hole in the upper end, and is picking out the kernel. Only one or two other birds know how to do this, and the habit is not shared by the rest of the tits, so whenever you find a lot of nuts wedged into crevices in the bark of a tree you may feel fairly sure that it is the work of a great tit. A species that has a similar habit is that curious little tree-climbing bird the nuthatch, but it is not nearly so plentiful as our friend the tit.

The best way to get to know the tits well is to hang up near your window a cocoanut, or a bone with a bit of meat left on it, for either is a great attraction, when you will soon have them coming to the feast, and you will be able to watch them at their acrobatic tricks, pecking away while hanging upside down, swinging happily to and fro while the wind sways the cocoanut, and in fact showing off their accomplishments. What dainty birds they are, so tidy and smart in their neat plumage, the blue tit being perhaps the most charming, though the coal and marsh tits are also very fascinating. The great tit puts on quite a lot of 'side'; he walks about on the lawn as if the place belongs 
to him, and when he comes to dine the other birds give way before him, for they know all about the pecking power of that short, sharp, stout bill of his. The winter over, the tit flocks break up, the old birds to go home to their nesting quarters, and the younger ones to seek a home. I firmly believe that all tits mate for life, and indeed that many other birds do too. I am sure that pairing is no light matter and that the majority of birds are far more faithful to each other than is commonly supposed. Only in this way can the regularity with which they return to their old nesting places be accounted for. Swallows and martins, for instance, invariably come back to the old home. My tits in the backyard pump nested there for eight seasons running; then came the awful winter of 1916-17, from which many kinds of birds have not recovered yet. Previous to that season the long-tailed tit was one of the commonest birds about my home. Every spring I found five or six of its exquisitely made lichen-covered domed nests, but the long-continued severe weather exterminated the poor little things, and I have hardly seen one since and have not found a single nest. The stronger, more robust great 212 


\section{SOME GARDEN BIRDS}

tits and blue tits did not suffer so much, yet many must have died, for they were not nearly so numerous the following spring. I think the pair belonging to the pump must have perished too, for it was not occupied that spring. Early in March a pair of great tits did turn up and go in and out of the pump as if househunting, but they went away again, and the pump stood empty all that breeding season. Had they been the old couple I do not think they would have deserted their home in this way. The visitors must have been a young pair looking for a nesting place. For another spring the pump remained deserted, but now it is reoccupied, and once more a tit family have been reared in it, and the hungry twittering of the young birds, together with the anxious chatter of the old ones, can be heard most of the day.

(The Pied Wagtail is known scientifically as Motacilla a. lugubris; the name of the Willow Wren, or Willow Warbler, is Phylloscopus t. trochilus, and the Great Tit is known as Parus major nerotoni.) 


\section{CHAPTER X}

\section{THE HEDGEHOG}

THe hedgehog is a shy little creature, living a quiet retired life, and only coming out at dusk when all the noisy creatures of the day have gone home to bed. When the dusk is falling, when the bats begin to flit to and fro, and the dor-beetle blunders noisily through the twilight, a stir and faint rustle in the grass will tell that the hedgehog is abroad, nosing here and there among the dew-soaked herbage for slugs and night-roaming insects. No wonder it only goes hunting by night, for it has no means of defending itself save its covering of prickly spines. These are its armour and defence. When danger threatens, all it can do is to roll itself up into a ball, and hope for the best. It cannot run quickly enough to get away, and its teeth are not strong enough to do much harm to a foe, therefore, whenever it hears any sound, it does not wait to see what is the matter, but straightway makes itself into a ball. 


\section{THE HEDGEHOG}

It is this ball of prickles-and very prickly prickles they are too-which most people think of when they speak of a hedgehog. Very few know what the creature is like when happy and unfrightened. When rolled up like this a hedgehog is well worth looking at carefully, for we have no other creature in England which defends itself in the same way, though in other countries there are animals with even longer spines, e.g. the North American porcupine, which with its long quills has carried the idea a great deal further than our little English hedgehog. However, as I have said, the latter is quite prickly enough, yet it is worth while picking one up and turning it over. How tightly it is rolled up! Even by pushing one's fingers into the spot where its head and tail meet one cannot force it to uncurl-indeed it only rolls tighter. The spines, about an inch long, stand out in every direction, and the more the hedgehog is frightened and annoyed the more tightly it contracts and the more the prickles stand on end. The rolling up is done by means of a powerful muscle which lies under the skin, being also used in raising the spines. These it will be found are very hard, but not brittle, so do not break easily, and 


\section{WILD CREATURES OF GARDEN AND HEDGEROW}

help to protect their owner not only from creatures which attack with tooth and claw, but from blows and falls. It can roll safely down from a height which would badly hurt any animal without elastic prickles to break its fall. The spines, which are prettily banded with brownish-grey tints, are thinner at the base than in the middle, and sharply pointed at the 'business end'; in fact, we can understand that the prickles form a most unpleasant mouthful for any one of the animals that earns its living by preying upon others, such as the fox and badger, and that a dog would have to be a very determined one, and be backed up and encouraged by a master, before it would willingly go at the prickly ball. In this attitude the little animal has all its soft parts well protected; all that is to be seen are the spines set in the leathery skin. We can imagine a young and innocent fox-cub out hunting for the first time by itself, seeing something move in the grass, how it would stand and gaze, dimly making out in the dark the round shape, then it crouching and springing, and the whine of annoyance and pain as pads and muzzle are pricked and stung by that living pin-cushion! After that it would 


\section{THE HEDGEHOG}

leave hedgehogs in peace-it would not want to jump on one a second time !

When not alarmed, what a different creature the hedgehog is from that ball of prickles we know so well. The spines lie down quite flat, being pressed evenly and closely to its body, so that they look almost like an ordinary coat of hair, and can hardly be told at a little distance from the grey hairs that fringe its face and cover its stomach and legs. Of course there are no spines mixed with the coarse hair on the under parts, for they would be no use here, and would only get in the way, being an annoyance and a hindrance whenever it rolled up. When it looks up on the alert it has a keen intelligent little face, sharp eyes like black beads, small ears hidden among the rough hair, a long snout, and sensitive nose, which has earned for it its name of 'pig of the hedge' or 'hedgehog.' In many parts of the country it is also called the 'urchin,' but the former name suits it best, for with its short legs, rather long body, tiny tail, and pig-like way of rooting about, the likeness is undeniable. Of course it has really nothing whatever to do with a pig, being a totally different kind of creature. Despite its short legs its movements are more nimble 


\section{WILD CREATURES OF GARDEN AND HEDGEROW}

than one would expect; it can climb quite steep banks in a surprising manner, and jog along over uneven ground at a fairly good pace, though not fast enough to get away from any enemy, nor even to catch the youngest of birds or rabbits, even supposing it wanted to do so!

Strictly speaking the hedgehog is an insecteater, disposing of great quantities of beetles, worms, and slugs in the course of a summer's night. If you find little oval lumps of black substance on the lawn in a morning, made up of crunched beetles' wings, you may know that a hedgehog was hunting the grass the night before. Gardeners should always take care of these animals, for they are a great help to them, getting rid of more slugs than anything else. While the man is finding and killing half a dozen, the hedgehog will have nosed out and eaten a score. But it is not called the pig of the fences for nothing; like its namesake it does not mind what it eats, it is not at all particular. If it should meet with some dead animal, with carrion of any sort, it will not waste the chance, but begin at once to make a good meal. Its little sharp teeth, though especially adapted for eating insects, do equally 


\section{THE HEDGEHOG}

well for chewing up rather 'high' meat. Supposing an urchin is hunting as usual for worms and beetles, smelling here, smelling there, pushing his sensitive snout in between the grass stems, finding many a slug, scores of worms, and endless insects, each being crunched up with noisy relish, yet leaving him hungry and unsatisfied, for small things like this do not take up much room, and it needs a very great many of them to make a satisfying meal. He is still hungry when his nose goes up in the air, sniffing, sniffing! Surely that smell means carrion? His eyes are not very good, he does not see far clearly, but his nose can tell fine shades of smell of which you and I have no idea, and this that now comes down the faint evening breeze is unmistakable, so he follows it up, waddling steadily forward as the smell gets stronger and stronger. To him it is delightful, and he plods on questing this way and that until his nose leads him to a dead rabbit lying out in the field. It has been killed some days, as can be told by its more than strong scent, its eyes are gone, picked out by a magpie probably, and the orange and black burying beetles who lay their eggs upon such carcasses have already come and are hurrying 


\section{WILD CREATURES OF GARDEN AND HEDGEROW}

about it like undertakers. The way the poor rabbit met its fate is plain enough, for there is a red hole bitten in the back of its neck; that is the work of the stoat, so the stoat, and he alone, is the culprit. But the hedgehog does not care how the rabbit died, all he thinks about is a good meal, and a dead rabbit like this promises a very good meal indeed. $\mathrm{He}$ is in such a hurry to get to work that he does not even take any notice when he feels that shake of the ground caused by a startled rabbit thumping with its heels to warn its friends that there is danger about. When anything frightens a rabbit that is out feeding, it always, before running away, hits the ground with its hind feet. The thump carries far, and tells all the other rabbits to look out, to beware. As a rule, the hedgehog pays attention to this signal, putting up his spines, and preparing to roll up, but he has already begun to eat, and for once takes no notice. Pushing his nose through the hole the stoat has made he chews steadily at the meat, eating with a noisy smacking of his lips and crunching of his teeth which iells how he is enjoying himself. He eats vulgarly, noisily, in fact like a pig! He is enjoying the meal so much 


\section{THE HEDGEHOG}

that he takes no notice of the rabbit signals which are being given all round him, though, usually, he is most sensitive to vibrations of the ground. White tails bob past as the rabbits flee to their homes, just shadowy shapes in the dusk racing for their holes. Something has evidently frightened them, but still the hedgehog goes on eating. At last he too catches the alarm, his spines rise along his back as he hears and feels the regular thump thump of a heavy-footed man coming near. It is the gamekeeper going home late. It is so dark that he nearly passes the hedgehog, but, catching a glimpse of something black in the grass, stops, strikes a match, and as the flame leaps up sees at his feet that ball of prickles, which a moment ago was a slim smooth animal. The hedgehog is on the top of the rabbit, which is partly eaten, so of course the keeper, who does not notice the rabbit has been dead for days, concludes the urchin must have killed it. Exclaiming, 'Drat these urchins!' he deals the poor hedgehog a blow with his stick. Not even prickly armour is any good against a heavy stick, his 'wait and see' attitude is this time fatal to the little animal, and next morning his body is swinging with crows, 
magpies, stoats, and weasels on the keeper's gibbet.

It is his pig-like taste for carrion which gets the hedgehog into no end of trouble, and earns him a bad character with those who do not take the trouble to find out if the meat that he eats is of his own killing or was slain for him by some quicker and more nimble animal. Another thing is that the hedgehog's teeth are not fitted for holding and killing big and active creatures. The canines-the big long teeth placed near the front of the mouth and of which you can see very good examples if you open the jaws of a dog or a cat-are too small in his case to give him a really good grip, though excellent for chewing. The result is that he will go anywhere for carrion, and many a hedgehog has met its fate by wandering into a trap baited with meat. The question of what this animal will and will not eat has been the subject of a good deal of argument between naturalists, some saying that it is very fond of eggs and hunts for those of the birds that make their nests upon the ground. I can only say that I have put eggs into the cage of a captive hedgehog, given it nothing else to eat, and left it for the night, yet the eggs were 222 


\section{THE HEDGEHOG}

not touched. The result was the same when I tried the experiment again. All the same, I can quite believe that if a hedgehog found out eggs were good to eat it would not waste its chances when it came across any, yet it is evident that by no means every one is an eggeater. Again, many people say that it is very fond of little birds. Certainly I would not like to trust one with a nestful of naked baby willow wrens in front of it, but it would have to be a very nimble urchin that could catch and eat lively pheasant or partridge chicks. Likewise if it found some very young and helpless rabbits in a hole it would hardly pass them by, but as a rule the mother rabbit covers up the mouth of the nursery with earth, padding and stamping it down with her feet so that strangers shall not get in while she is away, and by the time the hedgehog meets the young rabbits they can run many times faster than it. Of course it must never be forgotten when dealing with animals that they are just like us -no two are exactly alike. One will do one thing, one another. Some people are very curious, and will do things their friends would not dream of doing. It is the same with wild creatures; there are eccentric animals which do 
unexpected things, in every species there occur individuals whose habits and conduct are not those of their fellows, and very often it is these that earn a bad name for their kind. It is so with the hedgehog. People will tell you that it kills fowls, rabbits, sucks eggs, and so on. There is even a tale in some parts of the country that at night the hedgehog goes up to the cows as they lie sleeping in the meadows and sucks the milk! How such a thing could ever be believed I cannot understand. You have only to look at the sharp little pin-pointed teeth with which the hedgehog is armed to know it is impossible, for no cow would ever endure those sharp points pulling at her teats. Besides, how could a hedgehog learn about milking cows! Very likely the silly story has originated from the fact that where there are many cattle there are usually lots of insects; the 'cow-pats' attract numbers of dung-beetles, which of all things are what the urchin likes best, and such a spot will provide it with an excellent night's hunting, nosing about, turning over the manure, and finding the insects and their fat white grubs. If a person who knew nothing of hedgehogs and their ways saw it busy in this manner, that 


\section{THE HEDGEHOG}

person might conclude it was up to no good, might think it was after the milk, and thus give rise to the foolish tale. It is nearly as bad as the story which gives the nightjar, or goat-sucker, its name. The bird, which flies about hunting moths in an evening, has a very wide beak to enable it to catch the insects, so, in parts of the country where there are goats, the country people imagine that broad gape must be for the purpose of sucking the goats, and so 'goat-sucker' it is called!

Another tale that is sometimes told about the hedgehog is that it will steal apples, sticking them on its spines, and going home to its den with apples all over it! The persons who tell such stories forget, or rather do not know that this animal is no fruit eater, that under no circumstances will it eat anything of the sort, and that rather than touch an apple it would starve to death. How it is supposed to put the apples on its spines I do not know; perhaps it is thought to roll about among the fallen apples under the apple-trees until it has a full load!

On account of its imaginary crimes the hedgehog has always had a bad time, and in olden days the churchwardens of the different 


\section{WILD CREATURES OF GARDEN AND HEDGEROW}

parishes included it among the vermin for the killing of which they offered rewards. As much as twopence and even fourpence each was paid for urchins. Yet any one who will take the trouble to go out on a summer evening to any spot where he thinks there are hedgehogs, and wait, and watch, for a bit, will see for himself what useful creatures they really are. As long as you keep quite still the animal will not see you, for its eyesight is not good, and when intent on hunting and ground scents it takes no notice of a person. One evening, about 8.30, I met a hedgehog just starting out on its night's ramble. It did not see me and walked on towards me, turning aside to nose first in one hollow and then in another. It was noticeable how poor its sight was, for it showed no sign of knowing of my presence until only a yard off. Then it stopped and listened intently, its spines began to rise along its back, and its sharp nose slowly sank between its paws, being the first steps in preparation for rolling up. However I kept quite still, and at the end of three minutes it raised its head, licked its lips thrice with its red tongue, turned round, and began to hunt again. It was just like a little pig, 226 


\section{THE HEDGEHOG}

rooting here, nosing there, champing up first one morsel and then another. Suddenly I felt I must sneeze, do what I would I should have to, and like all suppressed sneezes it came out with a dreadful explosion. I expected to see the hog rolled up into a spiny ball, but, though the spines along its back rose in response to the noise for a moment, they soon went down again, and it went on hunting as before. Neither sight nor sound seriously frightened it, but the matter was different when I moved on: it curled up promptly, showing that it felt the thumps of the footsteps in an instant.

The home and living place of the hedgehog is generally down a disused rabbit hole in some dry hedge bank, but a crevice between stones, a cavity under an old tree stump, or a crack in a wall will serve it equally well if roomy enough, dry, and warm. Here it makes its bed, carrying in quantities of grass, leaves, and moss. I have watched a hedgehog making its nest. It collected mouthful after mouthful of leaves, carrying them, with its head rather high in the air, down a hole near at hand, and soon coming out again for more. It went on, journeying backwards and forwards, until it must have taken quite a lot of bedding in. It is, indeed, 


\section{WILD CREATURES OF GARDEN AND HEDGEROW}

wonderful how much stuff hedgehogs will accumulate in their holes, but it is not advisable to examine the lining too carefully as it is generally full of fleas! It must be owned that though this creature has many good points, cleanliness is not one of them, and it is usually swarming with exceedingly large and active fleas, which are a special kind peculiar to itself. When curled up in its snug bed an urchin will often get some of the dry withered leaves stuck on its prickles. I have seen them walking about decorated in this way, but of course it is only an accident, yet it has been said that the hedgehog purposely rolls itself about in loose leaves, so as to get a covering to keep out the cold !

As a matter of fact, when it is really cold the animal does not venture out. It is one of those creatures which hibernate, or sleep, during the winter. The very fact of this proves that it is really an insect eater, and that meat is only eaten when accident throws it in its way. During the summer, when insects and grubs of all sorts are exceedingly plentiful, it waxes fat. Night after night it gorges itself with more good things than it really wants, the unneeded food being stored away in its body in the shape of fat. Masses of fat 228 
accumulate until the autumn, when its weight will have increased by as much as a pound (one and a half pounds is about the average early summer weight), so that it is at the beginning of the winter nearly twice as heavy as in the spring. With this reserve in hand the hedgehog prepares its winter nest, carrying into the hole extra grass and leaves, and getting ready to face happily the very hardest weather. As soon as its food gets short, when the nights have become cold and chilly, few or no insects being abroad on the frosty grass, it drops its nose between its paws-having first drawn the bedding around it-curls up, and sleeps soundly for weeks on end. A warm day or two will wake it and bring it out to see what can be found, but as the late autumn merges into winter its sleep becomes sounder and sounder, it has become cold and lifeless, and so the time passes by until the warm spring comes, sending the life coursing through its veins again, and waking it up, to come forth lean and thin, all its plumpness gone, to search for food once more.

There is one most curious thing about the winter sleep of the hedgehog, and that is the change which takes place in its blood. In 


\section{WILD CREATURES OF GARDEN AND HEDGEROW}

blood there are two kinds of minute organisms, the one red, called the red corpuscles, which give the crimson colour we know so well, and the other white, and known as the white corpuscles. These latter act like soldiers and defend the body from germs. They fall upon the invaders and practically speaking eat them up. All day and every day the fight goes on; when we are ill the defending army has got the worst of it, when we get better it has conquered. These corpuscles are exceedingly tiny, and at ordinary times there will be as many as eighteen thousand to twenty thousand per cubic millimetre (a millimetre is the twenty-fifth of an inch) in the blood of a hedgehog. At the beginning of hibernation a great change takes place-only about one thousand to three thousand white corpuscles remain per cubic millimetre; they have invaded the tissues of the stomach, there to destroy the bacteria of putrification that have been brought in with its food, which otherwise could pass into the blood and destroy the animal. As soon as this work is done they are absorbed and disappear. In the meantime the blood has been reacquiring its normal number of corpuscles. ${ }^{1}$

1 G. E. H. Barrett-Hamilton, $A$ History of British Mammale, p. 65. 280 
Soon after the renewal of activity in the spring, hedgehogs begin to think of family affairs, and the males are said to be very quarrelsome at this time, but somewhat afraid of each other's spines. Two were watched walking round each other, nose to nose, but unable to get a grip, which circling they continued for twenty minutes, when at last ' each had hold of the other by a fore paw, and was shaking it as a terrier does a rat, puffing and blowing with the exertion. Sometimes one was uppermost, sometimes the other.' 1 I have never had the luck to see such a battle, and all those that $I$ have kept together in captivity have behaved very well, not being in the least quarrelsome or bad-tempered. Once I put an old female hedgehog in a box with some young ones that had been brought to me from a spot fully a mile away from that where the old one had been found, so she could not have been their mother, yet when in the evening I went quietly up to the box to feed them, I saw that I had indeed a ' happy family.' The old hedgehog was stretched out on her side, and the four young ones were lying in a row sucking away like little pigs at an old sow.

1 R. Service, Ann. Scott. Nat. History, 1901, pp. 232-3. 
They were having such a hearty meal that I drew back without disturbing them. I fancy the explanation must have been that the old hedgehog had a family of her own somewhere, and finding herself without them adopted these motherless ones in their place. At any rate, I returned them all, as soon as I could, to the hedgerow where the old one had come from, and have often wondered what happened to the family.

Baby hedgehogs are about two and a half inches long when born, blind and feeble, but already covered with spines. At this early age the spines are white and quite soft, and contrast oddly with their pale blue-grey skin. They rapidly darken, the skin becoming grey, and the spines hardening and deepening in tint. At first their little ears hang forward, nor are they able to contract into a ball, though when touched they try to do so, but only succeed in drawing down the skin of their foreheads towards their snouts. It is very difficult to keep little hedgehogs alive and well in captivity, as the mother dislikes being interfered with, and as often as not turns cannibal and eats her own babies. I had a family brought to me that had been 


\section{THE HEDGEHOG}

found in a mowing field. Apparently the old ' urchin' had made the nursery under some rubbish, an unusual site, for the mother generally gathers a quantity of leaves and grass down the warmest and snuggest rabbit hole that she can find, evidently preferring the quiet and safety of an underground nursery. At any rate this hedgehog thought differently, and the men who were cutting the hay heard a faint peculiar squeaking, and going to the spot found, under a heap of leaves and rubbish, an old hedgehog and three young ones which they brought to me. The little things seemed about a week old; they could not see yet, but their spines had hardened, and they could crawl about a little. All the time they kept up their curiously shrill bird-like squeaking. I put the babies into a small box out of which their mother could climb easily. She was very shy, curling up at the least movement, but as she ate well that night, made a nice nest for the family, and I found her suckling them the following morning, I hoped all would be well. All did go well for five days, then came the tragedy! I thought the old 'urchin' had a good deal of trouble to get in and out of the sleeping box, so out of consideration for her I 
broke the side of it away, so that she could step straight out. The young ones must have stepped out too, for in the morning not a trace of them was left! I could only imagine that, having crawled out of their nursery and wandered about until they became cold and unconscious, their mother had fallen upon them and eaten them. At any rate there was not a trace of any sort left.

Older families have done well with me. I had one that consisted of a mother and two little ones. The latter were about a quarter the size of their parent, and really very sweet little creatures. They were quite old enough to be able to roll up if they wanted to, but they had not yet learnt fear, and while their mother would curl up for nothing at all, they never attempted to. They would let me pick them up, stroke their soft grey throats, and seemed to enjoy being petted. As soon as they were put down they would run to and fro on the grass; indeed their activity made it very difficult to get a good photograph of the family. As fast as one was put in the right place the other had run away, and as for getting a picture of the two babies with their mother unrolled it was simply impossible. However, the trouble 


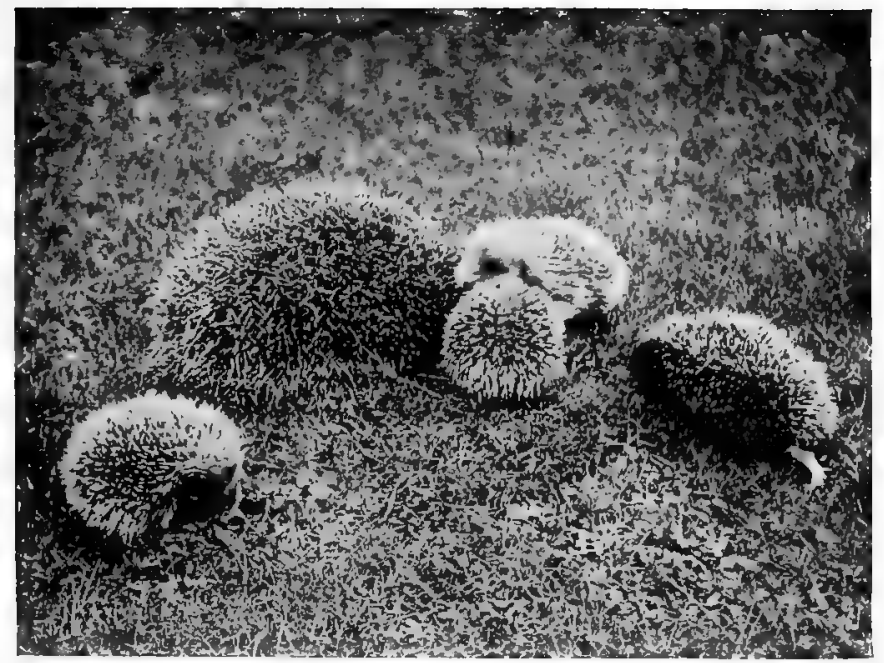

A HEDGEHOG FAMILY

The mother is rolled up and on the defensive

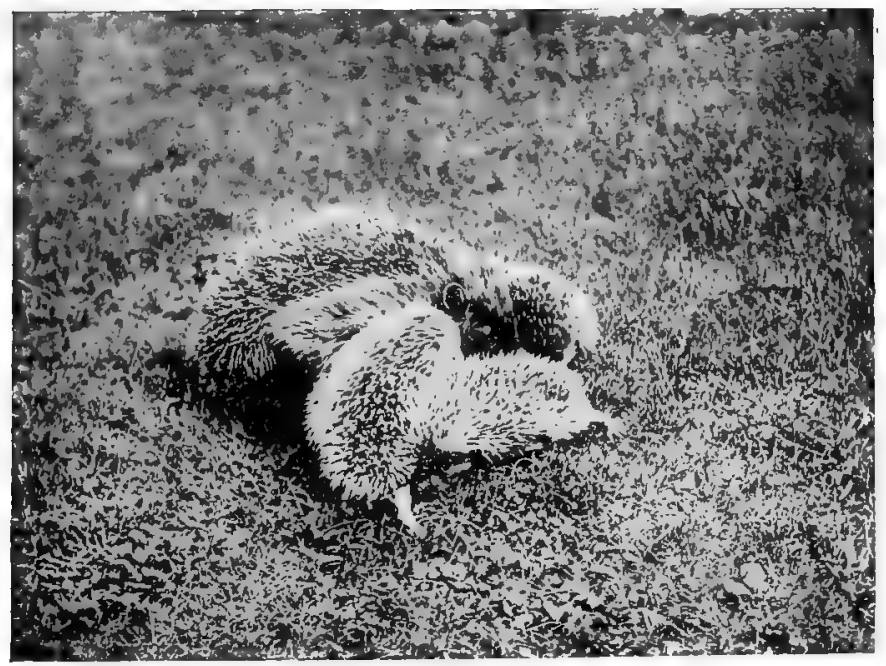

The old Hedgehog unrolls, and the young ones come to her to be suckled The latter are about four weeks old 

was nothing to that I had when I tried to get a picture of an old hedgehog and four young ones. They were perfect little demons ! They would not stop still for a second, and as fast as you brought one back the other ran off, and when all four were in front of the camera their parent was tightly rolled up, and there is one thing you cannot do, and that is make a hedgehog which does not choose to unroll.

To go back to the hedgehog that had two little ones-I felt that she treated me really very badly, for she would only poke her nose out at those moments when I was fetching back her runaway babies. At last I got everything right, and the old one appeared to be about to look up. Having put in the dark slide, I was just going to squeeze the bulb and release the shutter, when she briskly uncurled, toddled off, made straight for a pond which was but a few steps away, and took to the water before I could stop her, swimming boldly for the other side.

As a matter of fact, hedgehogs are remarkably good swimmers, and take readily to the water, not floating very high in it, but with back, head, and nose above the surface. I have several times seen them wade in and 


\section{WILD CREATURES OF GARDEN AND HEDGEROW}

paddle off when there was not the least need except that they chose to swim.

To go back to the subject of the young ones, even when of some size they keep up their shrill squeaking. This is quite different from the voice of the old animal, which, when it does give tongue at all, utters a subdued grunting noise. If hurt or terrified, the hedgehog will sometimes utter a piercing shriek, which has been compared with the wail of a baby, but as a rule it is silent. Hedgehog families are never very large, three or four being the most usual number, two being sometimes met with, five or six being more rare. The young may be born as early as April, but the majority come into the world during June and July, and sometimes later. When an early family has been brought up and got rid of, the second may be reared in August. Round my home the young ones are chiefly found in June, after the hay has been cut. Then one may see them as the light fades and the dew falls following their mother out to hunt for grubs in the newly cut grass. It is a quaint and charming sight to watch two or three little ' urchins' toddling to and fro, while their parent hunts industriously between the 286 


\section{THE HEDGEHOG}

stems. What a delight they seem to take in champing up the grubs they find, chewing them with noisy gusto. If you wish to have a tame 'hog' this is the time to get one, when it is old enough to feed itself, yet not old enough to have learnt fear. A most interesting and charming pet it will make, but there are one or two things of which you must beware-the first is to give it a good dusting of insect powder so as to get rid of the undesirable 'company' of which it is sure to have plenty, and the other is to see it is well and properly fed. It is no good giving a creature, whose natural food is insects and carrion, only bread and milk to eat, nor is it any good turning it loose in a black-beetle haunted kitchen and expecting it to fend for itself. In either case the end will be a speedy death. The hedgehog must be well fed; it may be given bits of flesh, mice, and rats (the latter may want cutting open), earth-worms, and bread and milk, or soaked dog biscuit, now and again. It should always have clean water where it can drink whenever it needs, and the more grub-hunting it can do for itself the better. It should have a good bed of hay or leaves, particularly in the winter, when it must not 


\section{WILD CREATURES OF GARDEN AND HEDGEROW}

be disturbed, though food should be handy, so that if it does wake up it may find something ready for it. When thus well treated it will get very tame, allowing itself to be handled without ever rolling up, eating readily from the hand, and letting you watch all its quaint little ways without fear or nervousness.

(Note.-The Hedgehog, Erinaceus europaeus, is found throughout Europe, including Great Britain and Ireland. Three sub-species have been described from Southern Europe, but the species shows no variation in the British Isles.) 


\section{CHAPTER XI}

\section{THREE COMMON REPTILES}

THE slowworm or blindworm is one of our commonest reptiles; it may be met with wherever there is long grass and thick undergrowth, and sometimes ventures out into the open to sun itself. In the garden round my home there is a damp ditch where the grass grows long and rank, which is the dwelling place of several of these little reptiles; but one does not often see them, for they are shy, nervous things, and slip about unnoticed between the stems of the grass.

The blindworm looks like a small snake, being usually about twelve inches long. It is a very big one which reaches eighteen inches in length, and anything over that length is a monster. It is a light brown or buff in colour without markings or pattern of any description. It is important to remember this, for the blindworm is often mistaken for a snake, and it is nothing of the sort, which mistake need 
never be made if it is borne in mind that both our common snakes, the grass snake and the adder, are prettily patterned and marked. Many scores of harmless blindworms get murdered in the belief that they are vipers. When people who know nothing of reptiles see a small snake gliding away through the grass, or lying basking in the sun, they do not stop to find out exactly what it is, but deal it a blow with a stick and there and then settle its fate. Such persons will seldom believe that the creature was quite harmless, being neither able to bite nor sting. 'We saw it putting its sting out,' they will tell you ! The so-called sting is really the little black forked tongue, which the blindworm, like many real snakes, has a habit of running over things. It is very difficult to make some people believe it is nothing more, for they are convinced that it is indeed a 'sting.' I have often let blindworms twist themselves round my hands, their tongues in the meantime flickering about my fingers, and those who have been looking on have still remained unconvinced, thinking that there was something strange about me so that the 'snakes' would not bite me. As a matter of fact not only has 240 
the blindworm no sting, but it cannot bite anything bigger than a very small grub or insect. Besides which it is, as $I$ have already mentioned, not a snake at all. It is really a lizard. A legless lizard, it is true, but still a lizard. Once upon a time in the long-gone-by ages it must have had limbs like most other lizards still have, for when its skeleton is examined the rudiments of legs can be found; however, these do not show externally, and to the outward glance it is quite snake-like. Perhaps legs were in the way when it was wriggling and gliding through the undergrowth; probably those blindworms with the smallest limbs were able to slip out of the way when danger threatened quicker than the rest, and in this way those whose legs were the least would time after time live and prosper, until during the long ages blindworms arose with no legs at all, which, being the best adapted for gliding in and out between thick-growing plants, would survive in greater numbers than those that still had limbs, so that soon the latter would disappear, and leave the legless ones to represent their kind.

Like real snakes, the blindworm moves along by means of the scales or plates that are 
arranged all down its stomach and underparts. They are movable, the animal pushing itself forward by means of them. By the way, it is darker, almost black beneath, contrasting prettily with the pale brown upper side.

Why this creature should have got named the 'blindworm' I cannot imagine, for it has a pair of exceedingly sharp amber-coloured eyes, that any one might notice at a glance, and with which, moreover, it can see perfectly well. Its other name, the 'slowworm,' is just as unsuitable, for it is far from slow, and I know to my cost the pace one can move and how difficult it is to catch it should it get away from you into the grass. More than once has a so-called 'slowworm' eluded me when trying to catch it among long undergrowthit glides so smoothly and swiftly in and out between the stems, disappearing at once in a quite mysterious manner.

Before going further I must give a warning, and that is to be careful how you grab at, or capture, a slowworm, not that there is the smallest fear of it hurting you, but you may damage it considerably, probably getting quite a fright yourself, for when pounced upon, or otherwise startled, a blindworm immediately 
throws off its tail. I mean what I say quite literally, for the reptile has the power, by a sudden contraction of certain muscles, of breaking off its own tail. The severed part begins at once a weird dance, writhing and kicking on the ground. Of course it is merely muscular contractions, such as keep an eel wriggling long after it is really dead. Nevertheless the broken-off tail will move for some minutes after it has parted from its owner, and on being touched will respond with further kicks. Even after five or ten minutes, life of a sort has not quite fled. In one instance a severed tail had still a wriggle left in it at the end of half an hour. In this case I was walking across a meadow when my attention was drawn to what at first glimpse $I$ took to be a small snake dancing in the grass, but which a second look showed me to be the tail of a slowworm with which its owner had parted. The slowworm itself was nowhere to be seen, but a kestrel's feather lying on the ground a little way off suggested a clue to the mystery. Probably the hawk had been hovering high overhead, watching for any unwary mouse which might come out to feed, when it had seen the lizard glide out to sun itself. Now slow- 


\section{WILD CREATURES OF GARDEN AND HEDGEROW}

worms are appetising morsels in the opinion of owls, kestrels, and such birds as prey on small creatures, so no doubt the hawk, after the manner of its kind, had dropped down from the sky upon the unsuspecting reptile, dashing, or rather falling upon it, and grabbing the first part that came handy, which happened to be the tail. But the slowworm was not so helpless as it looked; with a wriggle and kick it would be free, gliding off through the grass before the kestrel realised what had happened, and that it only held a bit of worthless tail. No doubt at my approach the bird had dropped this and had made off. As I have said, the tail was still wriggling when I came up, and continued to do so for some minutes. Unfortunately I could not stop long to watch it, but when I came back about half an hour later it was still able to respond to a poke. Truly the wriggles were but feeble ones, yet the muscles were still capable of some contraction when stimulated by poking.

What a strange idea it seems; fancy being able, when threatened by a foe, to throw off such an important part as a tail, and slip away, while it dances on the ground and occupies his attention!

The loss is not such a serious one to the 244 

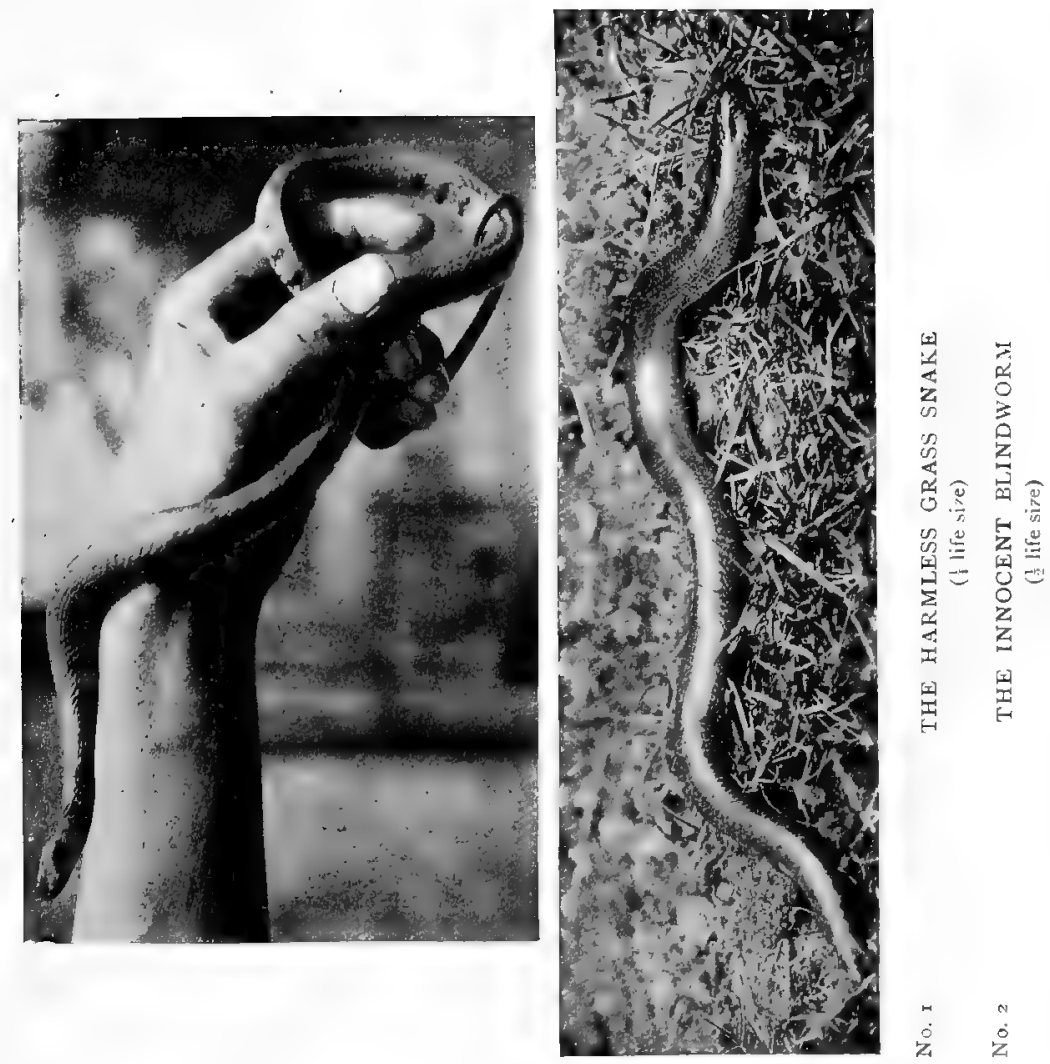



\section{THREE COMMON REPTILES}

slowworm as might be imagined, for it can grow another tail in the place of that which has been left behind. The new tail, it is true, is not so smooth and tapering as the old. It grows out as a blunt point from the place where the old one broke off, and you can usually tell at a glance a slowworm which has met with adventures and mishaps and had to part with the rearmost portion of its long slim body. Judging by the numbers of these reptiles that $\mathbf{I}$ have come across which showed signs of having had to renew their tails, it must be a common, not to say everyday, occurrence in slowworm life to cast off this useful adjunct.

The power of casting off the tail when badly frightened is shared by other lizards, including the pretty little common lizard, that is so plentiful in many dry warm spots. I once upon the Westmorland Fells caught a number of these quick-moving little creatures. They darted to and fro, catching a fly here, sunning themselves for a moment on a stone, then slipping into the crevices under the rocks, but by a dint of patience and poking under the stones I caught a good many of them. They were charming little lizards with their 


\section{WILD CREATURES OF GARDEN AND HEDGEROW}

quick bird-like movements and bright-eyed intelligent looks. I brought them home, and eventually turned them all out on an old sunken wall in the garden. The majority disappeared, but one, which I called Jemimia (or Jimmy for short), could be seen almost any warm day basking in the sun. She would cling to a stone with her sharp-clawed longtoed feet, flattening herself out in the heat until twice as broad as usual. Alas ! one day something else spied Jimmy when enjoying her sun bath, and that was the household cat. Now puss generally brought anything she caught to me, and I regret to say that the offerings laid at my feet varied from rabbits down to smaller and more excusable game. This time she arrived with what at first glance I took to be a small frog kicking in her mouth, but which turned out to be Jemimia minus her tail. The cat had pounced on the poor little lizard and in her fright the victim had shed her tail. I rescued Jimmy, and returned her to the wall, a bob-tailed lizard that had at the same time lost the greater part of her good looks. Whether she grew another tail or not I never knew, as she disappeared shortly after, having no doubt gone into hiding for the 


\section{THREE COMMON REPTILES}

winter, for lizards, including the slowworm, bury themselves as deep as they can and pass the winter in a long sound sleep. I looked along the old wall for her the next spring, but I never saw Jimmy again.

Lizards (which includes the slowworm) live on small grubs, insects, and worms, the common lizard being particularly clever at catching flies; spiders too are pounced upon and eaten in less time than it takes to tell. It was most amusing to drop some flies in front of Jimmy, and watch her cock her head on one side and fix her sharp little eyes on one of them. She would take a step or two towards it, then dart her head forwards, grab the fly, give it a quick bite or two, swallow it, and then wipe her head, like a bird cleaning its beak, from side to side on the grass. Small worms were attacked in the same manner, but as they wriggled and kicked she would often shake them savagely like a dog worrying a rat. When the worm had been disposed of she usually scraped her face with her fore feet to free it from bits, and then wiped it on the ground in the birdlike manner already described.

Every now and then slowworms and lizards become dull and dirty looking. This is a sign 


\section{WILD CREATURES OF GARDEN AND HEDGEROW}

that they are about to change their skins. The old skin splits down the head and neck and gradually peels off, leaving the late owner bright and clean in its new clothes. I managed to get a photograph of Jimmy when half-way through the change, with her old skin hanging in shreds from her neck and shoulders. When the last bit had peeled off she looked quite a different creature, for she was now prettily marked with green, brown, and greyish yellow. The common lizard varies very much; no two are alike, some being very dark, others quite light, some having a good deal of green about them, others brown, yellow, and stone colour.

The young when first born are practically black. They are wee creatures rather more than an inch in length, and from the first can run as fast as mice. The families are quite large, numbering as many as nine or ten. Jemimia's youngsters were nine in number, but, such being the custom among lizards, she did not worry herself about them, leaving them to look after themselves as best they could. Little lizards are quite independent from the moment that they come into the world, and scamper off, each on its own account, to catch wee insects and such tiny things as they can pounce upon 


\section{THREE COMMON REPTILES}

and hold. How active and quick these baby lizards are I only realised when I tried to get a photograph of Jimmy and her nine little ones. I arranged some stones and a piece of broken stick in a sunshiny spot, where I thought they might be persuaded to lie and bask in the heat! I little knew what a task I had set myself ! Two or three would allow themselves to be gently pushed into position, where they gradually flattened themselves out and began to absorb the warmth, then mother Jimmy would be quietly placed near them, whereupon two out of the three youngsters promptly scuttled off. To cut a long story short, after trying for over an hour and a half $I$ had to give up the attempt to get all nine before the camera, and merely take a picture of the old one and five babies. As fast as more were added to the group others ran away, and when the youngsters stopped for a moment it was the old lizard that got restless.

Little slowworms are also darker than the old ones, being coal black beneath, but somewhat silvery on the top. The slowworm is oviparous, that is to say lays eggs, but these eggs hatch at once, the little lizard breaking through the skinny covering and going off at 
once about its affairs. The newly born slowworm is about two and a half inches long, but, like the little wall lizards, is quite able to take care of and look after itself, and the old reptile most probably never sees its babies again.

At no age should a slowworm be confused with a true snake despite its snake-like appearance, for, as I have already mentioned, it is usually quite plain without any markings, whereas the real snakes are handsomely patterned. The only exception is that sometimes an old male slowworm may have a few spots along its sides, but even these should not lead to any mistake. Another easily remembered difference is that true snakes have no eyelids; their eyes are always open and staring, but lizards, and therefore the slowworm, have proper eyelids, so that they can shut their eyes, and in dead specimens this is particularly noticeable. Possibly it is the fact that this lizard can close its eyes which has given rise to the extremely unsuitable name of 'blindworm.'

As the adder or viper is usually only found on moors and on rough wild ground, we will not waste time and space discussing it here, but will go on to the common or grass snake, 


\section{THREE COMMON REPTILES}

which quite often appears in gardens and round houses, and is a true snake and no lizard in disguise. It is a very pretty creature, that is, if you are not too prejudiced to be able to see beauty in such a thing as a snake, being handsomely marked with dark patches on fawn-grey ground, which should not be confused with the diamond-shaped markings on the adder. The head of the common snake also differs in shape from that of the latter, not being so broad at the base. In the case of the adder the neck appears slimmer and narrower and the head decidedly broader behind. The common or grass snake is a perfectly harmless creature, never attempting to bite when handled and quite incapable of doing any harm if it did try. Its habit of running its forked black tongue over things that come in its way is trying to nervous people, who, as in the case of the slowworm, nearly always persist in believing that this is a sting. As a matter of fact, there is no snake which stings in the proper meaning of the word, though there are plenty in various parts of the world that can inject poison into a bite, this poison passing down the hollow fangs or teeth when the latter are pressed into a victim. Our common 


\section{WILD CREATURES OF GARDEN AND HEDGEROW}

English grass snake has no apparatus of this kind, but merely catches and swallows alive the creatures it wishes to eat. It lives almost entirely on frogs, and once a snake has grabbed one, the unfortunate frog has little chance of getting away. The snake's teeth curve backwards, so that it is practically impossible for it to let go. Once it has seized a frog and begun to swallow it, that frog has got to go on down its throat however big it may be, for the curved teeth make it impossible for it to come up again. However, a snake has an elastic throat, and a very curious arrangement of its jaws which enables it to swallow almost anything. The lower jaw is not fixed firmly to the upper, but only attached by very elastic muscles, so that when the snake begins to swallow an extra big mouthful its jaws become unhinged, they are out of joint, and stretch farther and farther apart as the frog or mouse passes down. Once the meal is safely stowed inside, the lower jaw slips back into place and into working order!

As the grass snake does not worry to kill any frog that it may be able to catch, but merely swallows it straight away, the unfortunate victim passes into its inside alive. I shall 


\section{THREE COMMON REPTILES}

never forget the piteous cry that I heard a frog give when thus seized by a snake. It was a pretty little foreign green tree frog, which, as I have mentioned elsewhere, had been left in the same cage with a grass snake that had gone on 'hunger strike.' The snake had not eaten naturally for so long, that I thought it was quite safe for a short time with the frogs, but a weird and heart-rending cry made me rush to the cage, only to arrive too late to do more than see the tips of the poor frog's little green hind toes disappearing down the snake's neck. It was impossible to rescue it, and I only hope that its sufferings were quickly ended by the strong digestive acids of the snake's inside. When a grass snake has had a good meal, it hides somewhere and sleeps it off, perhaps not coming out again for a week, for these creatures do not eat very often. In captivity they will often refuse to feed altogether, and would starve themselves to death if not fed forcibly. The snake in question, which recovered its appetite so suddenly and unexpectedly, had been hunger striking for two months, and I had had to feed it regularly. Once a week I caught a little frog, slew the poor mite, and then with the help of a blunt stick pushed the 


\section{WILD CREATURES OF GARDEN AND HEDGEROW}

corpse down the unwilling snake's neck. If one was not careful and did not push the food far enough, the snake would try and throw it up again, and one had also to be careful and not push it toó far down and hurt him. However, after the tragedy of the little green frog his appetite was all that one could wish; he gave no more trouble, but disposed of a half-grown frog once or twice a week.

As pets grass snakes are very nice, clean, and interesting. The only thing to beware of is that when first caught they are apt in their fright to eject a strong and evil-smelling liquid, but they soon get accustomed to being handled, indeed become quite tame, and then may be trusted not to do such things.

This snake is generally found in damp places, partly no doubt because the frogs that it lives upon like moisture, but also because the snake itself is fond of water. If one is kept as a pet it should always have a tin of water at hand, in which it will probably lie half its time, and it will also like a swim in a tub or tank; but don't take it down to the pond, for it can dive and swim so well that you will have great trouble to catch it again.

The common snake differs from the adder in 254 


\section{THREE COMMON REPTILES}

another important particular, and that is, it lays eggs, whereas the young adders are born as perfect little snakes. To hatch the eggs heat is needed, for without warmth they will never develop, so the snake, as she does not brood her clutch, has to find some means of getting them hatched. The means usually chosen is to bury them in a heap of damp decaying vegetable matter. Here the decay that is going on causes considerable warmth to be generated, and makes a splendid incubator for snakes' eggs. But better than any natural heap of leaves out in the woods and fields is a melon-bed, a hot-bed, or other heap of manure, so many a snake resorts to a garden to find a good nursery for her eggs. Of the risks she runs at the hands of the man in charge of the hot-bed she never thinks, but, wriggling her way in between the layers of hot manure, turns and twists until she has made a hole big enough to contain from twenty to forty skinny white eggs, each about half an inch long. The 'shell' is quite soft like that of the 'soft-shelled' eggs hens sometimes lay, and each egg is attached by the end to that next to it. If you open one while it is still fresh, you will see that it is just like a hen's egg, 
having a yellow 'yolk' and a quantity of clear ' white' or albumen round it. No doubt it would be quite good to eat, but personally I have never felt tempted to try boiled snakes' eggs for breakfast !

The mother snake, her task finished, crawls out and leaves the eggs to be hatched by the warmth of the manure, and, provided no one turns the hot-bed over in the meantime, they soon begin to develop, so that in two or three weeks' time the little snakes break through their skinny covering by means of a sharp point at the tip of the nose (which is shed the second day after hatching), and go off out into the world each about its own business.

Sometimes a grass snake will bestow her eggs in rather funny places, and in one instance the snake, not contented with getting into a nice warm manure heap, laid a number of eggs inside a glass jam jar or bottle, that had somehow or other got thrown out in the manure. The heap chancing to be turned over, the eggs came to light, and, owing to the kindness of the owner of the garden, the bottle and its contents were sent to me. As the bottle was not a very big one, it seemed rather a puzzle how a fair-sized snake had managed to 256 


\section{THREE COMMON REPTILES}

get in and deposit her eggs. At any rate, the jar was so full of eggs that not another one could have been got in. One of them which had been accidentally broken contained a halfdeveloped snakelet, but others were quite clear. Hoping they might yet develop into snakes I buried the bottle in a hot-bed, but evidently they had been too long in the cold, for they never came to anything.

Should you chance to find some snakes' eggs in your hot-bed, vegetable-marrow heap, or in some such spot, do not forget that they can be only the common grass snake's eggs (for we have but two other kinds of snakes in this country, the adder and the smooth snake, neither of which lay eggs), and that the grass snake is a perfectly harmless creature, doing no one any harm, so, instead of destroying them, it will be better to leave them alone to hatch out how and when they choose. If you should meet with the old snake treat her too with respect; don't think her ugly and horrible just because she is a snake, and then you will see that even a snake is beautiful and interesting, as indeed are most creatures if we look long and carefully enough at them. As for the fear of snakes that so many people express, it is, 
in the majority of cases, merely a matter of prejudice and not knowing anything whatever about the creatures.

To go back to the wee baby snakes; they live on small things such as insects, but they have many skins to shed before they too begin to hunt for manure heaps in which in their turn to hide eggs. Snakes, like lizards, and indeed all reptiles, change their skins periodically. Before the old coat is cast they are dull in hue, slow, and sleepy, but once it has split down the neck and they have wriggled and scraped it off, they come out smarter and brighter than ever. In the moult even the skin over the eyes is shed, for it is indeed a complete change in which every part of the covering is removed. How old snakes live to be is a very doubtful question, but some of them grow to a fair size, grass snakes as much as thirty inches long having been met with, though eighteen to twenty inches is a more usual length. Unlike most animals, they do not stop growing at a certain age, but can keep on increasing in size as long as they live.

In conclusion, I would beg any boy or girl who finds a snake hidden in the cucumber frame, the vegetable-marrow heap, or any 


\section{THREE COMMON REPTILES}

other spot beloved by the common snake, not to start back in alarm, and hit it with the first stick that comes handy, but to remember that it is only a harmless creature, unable to defend itself or hurt any one. That hiss which it makes when startled, the way it raises its head, and the forked black tongue which flickers to and fro, are not signs of a poisonous reptile, but merely the bluff with which a helpless defenceless one tries to make its enemies leave it alone.

(There are only three species of Lizard in Great Britain, namely, the Slowworm, Anguis fragilis, the Common Lizard, Lacerta vivipara, and the Sand Lizard, Lacerta agilis. The latter is only found in certain districts where there are sand hills, so has not been referred to in the foregoing account. Our snakes are also three, being the rare Smooth Snake, Coronella austriaca, which occurs in sandy districts in company with the Sand Lizard upon which it preys; the Adder, Viperus berus, chiefly found in heathery and moorland localities; and the common Grass Snake, Tropidonotus natrix, which is often abundant in our southern counties, but is seldom if ever found in Scotland, while of course it is absent from Ireland, as no snake of any kind is found in that island.) 


\section{CHAPTER XII}

\section{THE SHORT-TAILED FIELD VOLE}

The short-tailed field vole, or meadow mouse as some people prefer to call it, is one of the most plentiful of our smaller animals. Wherever there is long grass you will find the highways that it makes as it runs to and fro between the stems of the undergrowth. It lives on grass and literally eats out its roads before it. Wherever there is a colony of voles, there will also be found a perfect network of tunnels running in all directions through the grass. Even without opening them up you can get some idea of their many twistings and turnings, for the grass that has been bitten off underneath shows brown and withered on the top. This yellow withered herbage tells the tale of the roads that run through the forest of stems beneath, and that little furry brown mice race to and fro beneath its shelter. By running your finger along the highways and parting the over-arching grass you will be able 260 


\section{THE SHORT-TAILED FIELD VÓLE}

to see the well-used main roads, and the side lanes, with blind alleys again off them, which are the spots where the mice go to feed. By continually nibbling the grass at the end of these blind passages they extend their tunnels, and, as I said before, eat out their roads before them.

The meadow vole is quite different from our other mice; it is a small furry person with its ears buried in its long coat. It has small but keen eyes, a somewhat short head, a stumpy body, and a mere scrap of a tail. In all respects it is the exact opposite of the long, slender, large-eyed, big-eared, active, longtailed field mouse. The mouse looks like a gentleman of high degree, but the little vole in its rough, dingy-looking, brown coat, is but a commonplace little fellow. The meadow vole has more, but still not a great deal, in common with its distant cousin, the bank vole. However, they are not very alike; the bright chestnut colour of the latter should at once save any confusion between the two kinds. The creature that the meadow vole is like is the water rat (which should be called the water vole), for it, too, is a rough furry animal, with short ears and a short tail, but it is so much 
bigger than the little field vole, which is seldom more than four and a half inches from the tip of its nose to the tip of its tail, and often much smaller, that there is no chance of making a mistake and taking one for the other.

The vole's dull brown colour, with greyish under-parts, matches well the dark shadowy spaces between the grass stems, so that when it 'freezes' and does not move for two or three minutes, it is almost impossible to see it. It simply melts into its surroundings, and vanishes until some movement betrays where it is. All this is part of the difficult business of keeping out of sight of its foes-indeed a vole's life is one long effort to hide from its enemies, for once seen its fate is certain. Night and day death stalks at its heels, the brown owl and the kestrel prefer it to any other food, and the one by night and the other by day keep a keen watch for any unwary vole that ventures for a moment into the open. Many other creatures also help in the task of keeping down the numbers of the voles; the barn owl eats great numbers, the fox and badger do not despise them, and near the coast the different gulls share the work. The prowling cat accounts for a good many, the crows, magpie, 262 
and jay lend their help, the stoat catches a few, and last but not least comes the weasel, most deadly foe of all.

From the moment the baby vole leaves the snug nest of shredded grass in which it was born, it begins a life in which success goes to those who are always 'wide-awake,' never take chances, or leave anything to luck, and in moments of danger can best make themselves invisible. By success $I$ mean the feat of growing up and living to rear a family, for success in Nature consists of rearing and sending out into the world more young ones than your neighbour. There seems little doubt that it is by selection-that is to say, by the killing off of all voles whose coats have been either too light or too dark to hide well among the grass-that the dull dark brown fur of the meadow vole has been produced. It is not that it matches either the stems of the grass, or the bare earth, but it goes wonderfully well with the shadowy spaces between the plants.

When any sound is heard or anything seen moving, a vole either tumbles headlong down the nearest hole, or crouches where it is, trusting to the over-arching grass and its own invisibleness to save it. If the alarm was a 


\section{WILD CREATURES OF GARDEN AND HEDGEROW}

false one it will in a few minutes sit up and wash its face (for, like so many other mice and voles, it is a most clean and particular little creature, and always washes itself after a fright), and then goes on nibbling once more. It is an enormous eater, constantly nibbling at something, and, being found from the mountain tops to the seashore, can do much damage when its numbers get too great. What it prefers is the delicate white parts of the grass stems, generally leaving the coarse green tops to dry up and afford shelter over the runs. The alarm being over, the inhabitants of the holes will come scuttling out, hurrying along the runs to spots where the food is good, where the grass is luscious and soft, not hard and coarse, and then they set to work, nibble, nibble, nibble all the time. One foolish young vole pushes its head up and out through the covering grass so as to get a peep at the great wide world that lies so fair in the sunshine, but it does not see a small black speck high up againist the blue of the sky-indeed it has no time! Down like a thunder-bolt falls the kestrel, who has been hovering up aloft, and watching the meadow for some such movement in the grass. There is a thump, a 264 

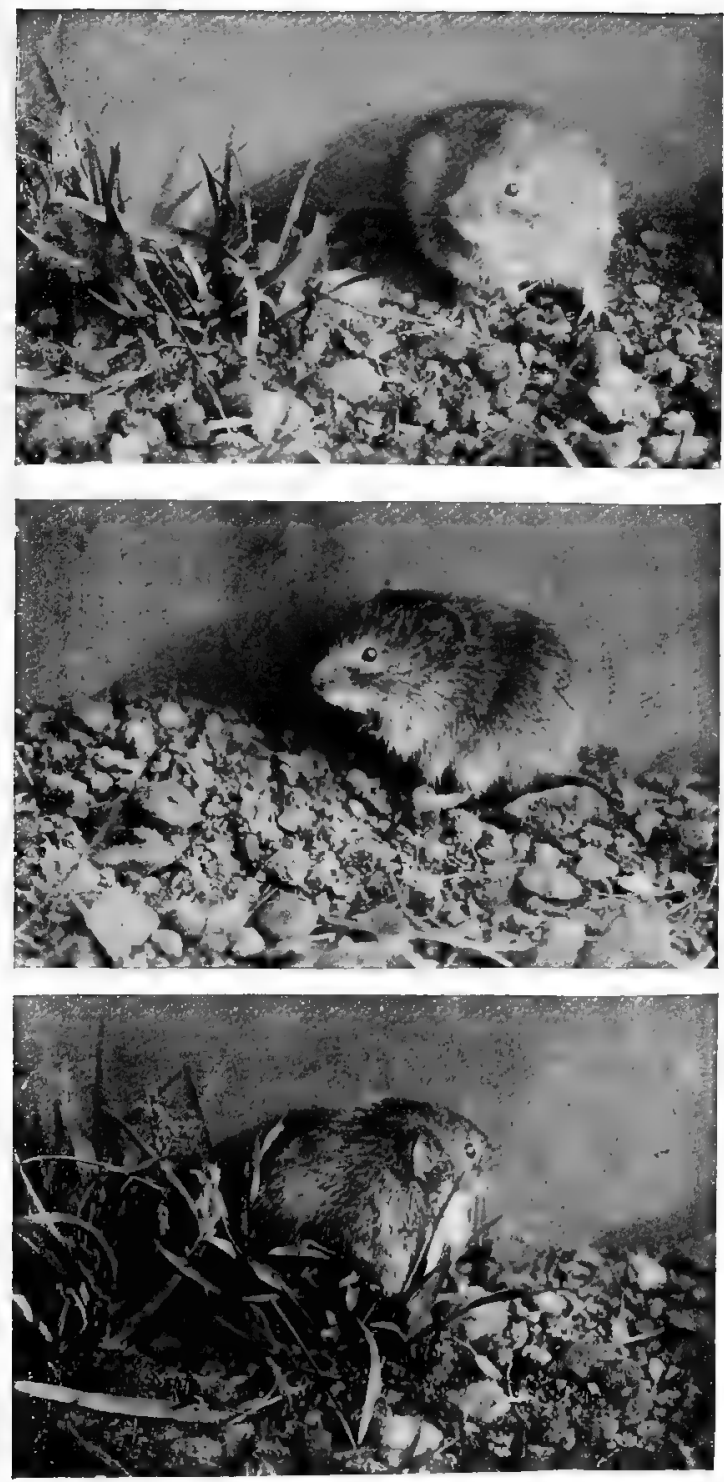

THE MEADOW VOLE, OR SHORT-TALLED FIELD MOUSE,

(t) life size) 



\section{THE SHORT-TAILED FIELD VOLE}

muffled squeak, and off flies the little falcon with the vole in its claws. The kestrel's chattering cry is heard, and then silence sinks on the colony, save for the song of a lark far overhead, which is singing at a height even greater than that at which the kestrel was 'waiting on.' 1

However, fear does not last long with these small creatures ; they do not waste time looking for a friend who has disappeared, or in wondering what has happened. Friends and relations daily vanish, they go no mouse knows whither, so they do not worry; while food is good and plentiful it is a case of gnaw and nibble and do not bother. Young mice grow up to take the place of the old, and on the whole the numbers of the colony remain about the same.

The danger past, a mouse or two sits up and washes its face, then they set to work to nibble more busily than ever. One runs to this blind alley, another to the next, some sit on the doorsteps of the holes and clean and preen themselves; others, tired by hard eating and by the fright, go down the holes and sleep in warm beds made of shredded grass tucked

1 'Waiting on, a term used in falconry when the hawk waits and watches for its prey to be put up beneath it. 
away in private corners. One or two of the passages, which are as many underground as there are highways on the surface, lead to extra well-made nests that are guarded by fussy old mother voles, who have young ones hidden away among the bedding. In the early part of the year the nurseries are usually underground, hidden at the end of some passage where the rest of the colony do not wander, but later in the season they are all made above ground, a nest of woven grass being made somewhere where the herbage is extra thick and gives good shelter. Indeed, the majority of young voles are reared in the open air, despite the dangers to be met with on the surface. They may be trodden on by wandering cattle, nosed out by the fox or badger prowling round at midnight, or if in mowing grass the nest may be cut into by the mowing-machine, besides which there is the weasels' liking for tender young voles. The weasel is by far and away the worst of all the field vole's many foes-so small and slim as to be able to slip down the smallest of mouse holes, gifted with a wonderful ' nose' so that it can follow the faintest of trails, dogged and persistent to the last degree, there is but 266 


\section{THE SHORT-TAILED FIELD VOLE}

little hope for any mouse that it once begins to hunt. No matter how the unfortunate vole turns and twists, doubles and tries to confuse its trail with that of other mice, the weasel will follow the scent through all the burrows and pathways until it at last comes up with its victim. A weasel's presence in the 'runs' causes instant terror among the mice; they rush frantically in all directions, though, like a rabbit hunted by a stoat, they do not go far before they stop to listen and see whether the weasel is really on their track or that of some other vole, for if the latter they can slip quietly home again. But the poor little mouse that the weasel is really hunting is doomed-nothing can save it; all it can do is to run wildly on, hoping, if it has the wits left to hope, that the hunter may change to the line of some other vole, which is a most unlikely thing to happen. For no creature knows better the arts of the chase; it is well aware that if it were continually changing, it might hunt all day and never catch a mouse, so it sticks to the first trail, puzzling out with patience the places where the scent is crossed by trails of other voles, and becomes so intent on the hunt as to have no eyes, ears, or nose 
for anything else. In the meantime the desperate vole will go anywhere and do anything to try and throw off the weasel; it will cross broad highroads, dash across the open in front of onlookers, and even take to the water and swim streams and ponds. Once I saw a field vole dash across a road almost under the wheels of a pony trap. The driver stopped the pony, and we waited and watched to see what would happen; a second later a weasel appeared running along the fence at the side of the road, from which it jumped down into the ditch, hunted up and down the muddy bottom for a moment, picked up the scent, and with its nose to the ground sprang out on to the grass that edged the highway, where it hesitated for a moment, cast itself in a circle as a huntsman casts a pack of foxhounds, recovered the line, and, paying no more attention to us than if we had not existed, bounded across the road with that curious light dancing movement peculiar to stoats and weasels. It disappeared on the farther side into the long uncut grass of the ditch. All was still, not even a grass blade quivered, and we thought the hunter and hunted had gone, but just as we were moving away something 268 


\section{THE SHORT-TAILED FIELD VOLE}

stirred in a little gutter that carried the water from the road down to the ditch. It was the weasel, and it carried the vole dead in its mouth. This time it saw us, paused, sat up on its hind legs, and looked at us inquisitively. It turned back into the ditch, but, not quite satisfied, looked out again-still with its victim in its mouth, but the pony moved, and this time the weasel disappeared for good. Probably a few moments later, the mouse having been eaten, it was hunting again, for it not only hunts for food, but for sport, enjoying the chase for its own sake, which is why it is such a terrible enemy to all mice.

Though hard luck on the poor little voles, it is really a very good thing that the weasel, the kestrel, the barn and the brown owl keep such a strict watch over them, for they increase at a great rate, the families generally being five or six in number, but often reaching as many as nine or ten. In a mild season the young ones will begin to arrive as early as February, indeed they have been found during an open winter even at Christmas time, and the same pair of parents will have three or four more litters in the course of the summer, so that by the autumn the one couple will have 
thirty or forty young ones! In a good season, that is to say when the weather is fine and warm and enemies are few, each pair, supposing they had five families of nine or ten apiece, would have from forty to fifty little voles. No wonder that under these circumstances they increase until they become a perfect plague. The grass becomes riddled with their runs, all that is good and green is eaten, only brown withered stuff remains. Short of food, the increasing swarms stray into the woods, kitchen gardens, and wherever there is anything green to eat, and do great damage to all sorts of plants. In the meanwhile the owls and hawks are enjoying themselves most thoroughly, eating mice all day and every day until so gorged they cannot swallow even one more. Owls and hawks from other districts, somehow or other discovering the good things that are to be had, arrive to share the feast; indeed birds of prey come from all sides, and dogs, cats, and foxes gorge themselves day after day. Still the mice increase, fields are gnawed bare, trees are barked in the woodlands, and the damage done becomes so very serious that everybody tries to put a stop to the plague. There have been many plagues such as described, 270 


\section{THE SHORT-TAILED FIELD VOLE}

the last serious one being that in Scotland in 1891-92-93 - the grazing lands of southern Scotland were afflicted to an extent involving an area of not less than sixty miles by twelve to twenty.' 1

The end of these plagues is always the same : disease breaks out among the voles, they die by hundreds and scores of hundreds, the birds of prey that have gathered from afar find food growing scarce and depart for their homes, and the dwindling mice get fewer and fewer, so that at last they are reduced not only to their usual numbers but far below.

Frosty winters, when all grass and green food is dry and frozen, do much towards keeping field voles from getting too many. Snow they do not mind, it keeps their burrows snug and warm, and they can tunnel beneath it in search of food in peace and safety; but dry 'black' frosts are much more serious for them, and after the long hard winter of 1916-17 there was not a colony of voles to be found about my home. As a rule there are plenty, even in the garden, where they have their headquarters in a rough bank. This bank is planted with daffodils and narcissi, and the grass is not cut

1 Barrett-Hamilton, British Mammals, p. 450. 
until the middle of the summer, so the mice have quite a good time, and even in the winter there is a good deal of rough herbage to shelter them. By the way, voles are not quite so active in the cold weather as in the warm; they do not go into a winter sleep, they never hibernate, but have to come out and look for food whatever the weather. To go back to the voles in the narcissi bank-though these mice often get the credit for eating bulbs, this colony have never made the least difference to the daffodils. I have found that what they really like is crocus bulbs, but that no variety of daffodils appeals to them at all. I have also tried tame ones with snowdrops, but they would not touch them. They would hardly touch anything but green foods, grass being their chief diet, varied by lettuce, of which they were very fond, and dandelion leaves, which they liked nearly as well. They would also eat the growing blades of wheat, barley, and oats, but the grain itself they did not seem to think much of. Clover they liked, also water cress, and they were fond of dock seeds. Fruit, especially apples, was much appreciated, strawberries and gooseberries being by no means despised, but my voles had evidently 
a liking for sweet things, as they gnawed greedily at a lump of sugar that I dropped into their cage, also licking up jam and honey. Once I saw one catch and eat a fly that had ventured into the cage, and the same mouse ate another that I caught and put before it. Small earth-worms were always attacked, so there can be no doubt that in a wild state the field vole eats a good many insects and grubs. Like many other small animals it is certainly not above tasting flesh if it chances across a corpse, and, as I shall have presently to describe, will even sometimes eat its own friends and relations!

Though I have given quite a long list of things which I have found that voles will eat, there is hardly anything which they are sufficently fond of to be any use as a bait for trapping them. Cheese does not attract them, and they are the most difficult of all small creatures to catch. The only bait that I have found any good at all is a split yellow crocus bulb. Even then $I$ am not sure if luck has not more to do with the voles being caught than anything else. Indeed I quite believe that an unbaited trap set in a vole's run is just as likely to catch one as a baited! 
This being so, it may be asked how I managed to get the mice which I kept for some time to watch and study. One I disturbed when walking through some long grass, pounced on it, and managed to grab it, carrying it home in my pocket-handkerchief, the vole in the meantime amusing itself by nibbling holes in the handkerchief, so that never again was it any use. The second had made itself a warm and comfortable bed under a cock of hay, in which nest it was no doubt sleeping happily when a pickle was thrust into the hay and its covering rudely torn off it. I was standing by, and as the man raised the cock $I$ saw the startled mouse run away. Before it had time to recover its wits $I$ had grabbed it and, despite the fact it began to use its small but sharp yellow teeth on my fingers, kept hold of it until it was put safely into a pocket, therein to be carried to join the other vole in its cage in the sitting-room. The first comer, instead of being pleased to have company, greeted it with angry squeaks. Rising on their hind legs they glared at each other; they thrust with their little paws, they boxed, and revolved round each other in furious combat, their abusive squeaks continuing the while, 274 


\section{THE SHORT-TAILED FIELD VOLE}

and, though they were both females, I fear the language was most unladylike. Presently they retreated to opposite corners and there washed their faces. Again they came out, and once more danced squeaking round each other; but the fighting did not last so long this time, and a longer interval of peace succeeded. At last they settled down, and before night were sleeping happily together in the same bed.

Apparently what happens in a wild state is that in the spring time a pair of mice will go off by themselves, make a nest in some snug corner, and from it, as headquarters, begin to tunnel in all directions. As their families grow up the party gets larger and larger, for they are good-natured creatures with those they know, and the old ones do not turn the young out into the world. By the end of the summer, what in the spring had been a solitary couple founding a colony has now become a large and well-populated settlement, of which all the members are related to one another. They know each other and are on the best of good terms, but woe to the stranger from another clan that ventures into their highways and byways, for he will soon be bundled out neck and crop, if he suffers nothing worse at their hands. 
The third vole was a big buck, and of the way I came by him I am rather ashamed, for he was turned out of house and home by decidedly unfair means. Down by the pond in the garden was a system of vole runs, at which my brother and I were looking one day. There was a hole going apparently straight down into the ground, and my brother, who had the watering-can in his hand, looked at me and said, 'Just a little water and the mouse would have to come out.' 'It seems a mean thing to do!' I answered weakly, as a steady stream of water poured down into its stronghold. There was a gurgling sound, something was coming up the hole, and a moment later a large meadow vole shot out of it like a Jackin-the-box. He came out with such a jump that he sprang straight into the pond. Already half-drowned by the water in the hole he did not swim as well as he would otherwise have done, but a butterfly net was near, and with it he was soon rescued. However, the cold and wet had cramped him so that I rushed off with him to the kitchen fire, and holding him before the blaze awaited results. In a minute or two he evidently felt better, for he sat up and began to lick himself and put his fur in order. Then 276 
he squeaked when I moved my fingers, giving me, when I put my hand over him, such a sharp nip that I nearly dropped the old fellow. As he seemed quite recovered I took him to the cage and put him in with the two females. It was evident that he was now quite all right, for when they popped out of their nest to see who was coming he not only squeaked at them, but boxed their ears in turn. They did the same for him, after which greetings they behaved more civilly to one another, and presently I saw him go home to the nest with them. Though this particular old male was a very fine mouse, it is not always the males which are the biggest; some of the females grow to a large size. Meadow voles vary a good deal, some being much bigger than others, and I believe they go on growing until quite old, at any rate, until after they have brought up a family or two.

My three voles soon settled down and made themselves at home. They ate surprisingly, grass and lettuce leaves disappearing at a great pace; indeed they seemed to spend their whole time nibbling at something or other. Their method of eating always interested me, for the blade of grass was cut off with the teeth, 
held in the mouth, and, the vole having sat up on its hind legs, then transferred it to the hand-like fore paws, when it was a matter of nibble, nibble, nibble, until the grass had gone. I never saw one of these voles eat in any other attitude, and the way they did it always made me think of a person eating celery. They were just as particular about the care of their fur as the more dainty-looking, long-tailed field mice, washing themselves frequently, and always after being startled. They would sit up on their hind legs, and licking their 'hands' pass them quickly over head and ears, then turn to their body, and dress every scrap of fur. They might not be so sleek and smooth-looking as the mice just mentioned, but still they were very dainty fascinating small creatures. They got quite tame, and took no notice whatever of things which moved on their own level. For instance, if I tapped on the glass side of the cage, any vole that was out eating would barely trouble to turn its head to see what the noise was, yet if so much as a shadow moved overhead, that same mouse would be gone in a flash. It was evident that they regarded the worst dangers as coming from above. Time after time $I$ tested them, and it was always 278 
the same result--anything on the ground level did not matter, but that which was overhead was to be feared. Though tame in the sense that they were not afraid of one's hand, did not run away, and would take food from the fingers, yet they resented being touched, and if I attempted to stroke a vole it invariably stood up, squeaked, and struck at me with its fore feet.

Some time after they had settled down happily, I began to suspect that something interesting was going on in a new nest that had appeared in one corner of the cage. Very faint squeaks could be heard occasionally, but I took great care not to in any way interfere, for mice when upset are apt to kill their young ones, so the cage was not cleaned out, and even fresh food was carefully put down on the opposite side of the cage to that where the nursery was placed. I did not wish for a repetition of a horrible murder such as $I$ once saw happen. In that case I had found a field vole's nest in a hayfield, and more by luck than anything else caught the mother as she ran out of it. With some difficulty, for she kept nipping my fingers, I got her into my handkerchief, after which I examined the nest. 
There was at least half a dozen naked blind pink babies in it. They might have been a day old but were certainly not more, for the wee mites were only about half an inch long. If they were left where they were they would certainly be killed, as they were right in the track of the men and wagons that kept going backwards and forwards, so I picked up the nest and family and took them all home, thinking that if I gave them a comfortable place to live in they would be all right and that I should see how baby voles were brought up. It was a glass-fronted cage that I put them into, so, having provided everything that they could possibly want, grass, lettuce leaves, water, and even a wisp of hay to make some fresh dry bedding, I sat down some way off to watch what the mother would do. First of all she washed herself carefully, then she went to the nest, in which the little ones were lying quite quiet and still, pushed aside the finely shredded soft covering and pulled out one of the babies. Before you could guess what was going to happen, she had given it a sharp bite and killed it. She murdered them all !

What made her do it? Was it to save them from an unknown fate? Or was it wild fear 280 


\section{THE SHORT-TAILED FIELD VOLE}

and excitement, so that she did not really know what she was doing? All I can say is that she acted perfectly coolly and collectedly, and appeared neither hurried nor flurried; but how can we tell what her motives were, or what caused her to act as she did act?

Fearing that if I looked at them the latter family might come to a similar untimely end, I did not even peep at the babies until they crawled out of the nest of their own accord. On the 3rd June a little vole toddled out. It was clothed in a smooth thin coat of brown fur, and was a very babyish little person. Its head looked much its biggest part, and a feeble attempt to sit up and wash its face was a failure. But it managed to sit up and eat some grass. Next day there were two or three peeping out, and by the third day I was convinced that the family was no small one. On the 7th I knew there were at least nine, but they grew so quickly, and were now so active, that they were most difficult to count, and you could not be sure to two or three. Their mother no longer worried herself about them; they were able to eat well, and already quite independent, so I made up my mind to 
put them in a cage by themselves, and on the morning of the 8th secured them, one by one, and moved them over. They were no less than ten! By July 11th another family had been reared, reached independence, and set free in the meadow. These were but five. When catching up this lot I found that there was another litter of five, quite young ones, perhaps three or four days old, but I could not be sure which vole was the mother. By July 21st yet another family had turned up, six in number this time, but the same day I found one of the old mice lying dead under a heap of grass. Shocking to say, her friends had been acting on the principle of 'waste not, want not,' and had begun to eat her. What caused her death I did not find out, but perhaps it was the worries of so many young ones. The other female did not look well, and I grew anxious lest she too should be going wrong. However, she managed to rear her family. In the meantime old 'Billie,' as we called him, had disappeared. What became of him I could not find out. That he was not in the cage was certain, yet how he could have got out of it was a puzzle. The mystery was never solved, and I only hope that he got safely away out of 282 


\section{THE SHORT-TAILED FIELD VOLE}

doors. As there was now only the one mother and the six young ones left, I took them out into the garden and set them free in some long grass. They slipped away like brown shadows between the stems, and that was the last that was seen of them.

How quaint and amusing they had been, perhaps their funniest habit being that of taking jam or honey off the end of a pencil. I have already mentioned how fond of sweet things they were, so when we wanted to give them a treat my brother and I used to dip the end of a pencil into the honey jar, and then hold it towards one of the voles, when, standing up on its hind legs, it would take the pencil in its fore paws and carefully lick off every trace of sweet stuff.

A point that always struck me was the good nature of Billie, who never interfered with or otherwise ill-treated any of the many young ones that were continually running about the cage. He never showed the least bad temper with them, but field voles are in general very easy-going creatures, and it is only strangers who are attacked. Just before I turned the old female out, a new female was put in her cage, thinking that she might be glad of the 
company, but she flew straight at her, and the fight was so furious that $I$ had to remove the stranger for fear she would be killed.

Charming and fascinating as the field vole is, it must not be forgotten what a serious matter it is when the little creature increases too much. It can multiply so fast that were there nothing to check it, it could in the course of one summer overrun the country, eating the land bare before it. It is to the owls, hawks, and weasel that we owe it, in great measure, that a mouse plague is really rare. This is why it is such a mistake to kill the vole-eaters-they are our friends and helpers. By not interfering with them we preserve the 'Balance of Nature,' and then no animal gets too plentiful; there is just the right number of each, and so all is well, no kind being plentiful enough to do harm.

(The Meadow Vole or Grass Mouse of Northern Europe, which was named Mus agrestis by Linnæus, has been found by modern systemists to consist of a number of forms, no less than eleven species and sub-species being recognised in the British Isles. As only two of these are found on the mainland, the rest belonging to the Orkneys and to the Hebrides, 284 


\section{THE SHORT-TAILED FIELD VOLE}

it will be sufficient to say here that the common Meadow Vole of England is known scientifically as Microtus agrestis hirtus, and that a larger and darker Vole found in the Highlands of Scotland is called M. agrestis neglectus.)

\footnotetext{
Details of books likely to interest readers of

-Wild Creatures of Garden and Hedgerow' will be found overleaf.
} 


\title{
BOOKS ABOUT PLANTS
}

\section{THE NATURE STUDENT'S NOTE-BOOK}

By Rev. Canon Steward, M.A., and Alice E.

Mitchell. Interleaved with Writing Paper.

Contains Nature Notes, Diary, Detailed

Classification of Plants, Trees, Animals, and Insects.

\section{jo \\ B O T A N Y}

An Handy Scientific Text-Book. By E. Brucker. Illustrations.

(Thresholds of Science Series.)

\section{0}

\section{PLANT PHYSIOLOGY AND ECOLOGY}

By Frederic E. Clements, Ph.D., Professor of Botany in the University of Minnesota.

I25 Illustrations.

\section{so}

COTTAGE GARDENING, as Taught n Elementary Schools. By GeORGE H. TAYLOR, F.R.H.S.

\section{so}

INSECT PESTS AND PLANT DISEASES in the Vegetable and Fruit Garden. By F. Martin Duncan, F.R.M.S., etc. Author 'Cassells' Natural History,' 'Wonders of Insect Life.' Illustrated.

A Text-Book for the Amateur Gardener and Allotment Holder

\author{
jo \\ CONSTABLE \& COMPANY LTD \\ IO-12 ORANGE STREET \\ LONDON, W.C. 2
}




\section{BOOKS ABOUT ANIMALS}

ECONOMIC ZOOLOGY \& ENTOMOLOGY An Elementary Text-Book. By VERNON L. KELLOGG and C. W. DOANE.

Devotes special attention to the economic relations between scientifically classified animal groups.

so

\section{Z OOLOGY}

An Flandy Scientific Text-Book. By E. Brucker.

Illustrations.

(Thresholds of Science Series.)

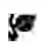

FARM ANIMALS: HOW TO BREED, FEED, CARE FOR AND USE THEM

By E. V. Willcox, Ph.D., of the U.S.A. Department of Agriculture. Fully Illustrated.

5

EXTINCT ANIMALS

By Sir E. Ray Lankester, F.R.S. Portrait and numerous Illustrations. Revised Edition.

e

OUTLINES OF EVOLUTIONARY B IOLOGY

By Arthur Dendy, D.Sc., F.R.S. Professor of Zoology in the University of London, etc. etc. Second Enlarged Edition. Fourth Impression. Fully Illustrated.

\footnotetext{
$\infty$

CONSTABLE \& COMPANY LTD IO-I2 ORANGE STREET LONDON, W.C. 2
} 


\section{HENRY DAVID THOREAU}

The Riverside Edition of Thoreau's

Works in II Vols.

A WEEK ON THE CONCORD AND

MERRIMAC RIVERS

WARDEN : OR LIFE IN THE WOODS

THE MAINE WOODS

CAPE COD

EARLY SPRING

SUMMER

AUTUMN

WINTER

EXCURSIONS

MISCELLANIES

FAMILIAR LETTERS

gr

\section{ERNEST THOMPSON SETON}

Readers for School Use

LEGEND OF THE WHITE REINDEER

BIOGRAPHY OF A SILVER FOX

THE SLUM CAT

LITTLE WAR HORSE

MONARCH THE BIG BEAR

For particulars of these

Readers and of other works

by Ernest Thompson Seton

write to

CONSTABLE \& COMPANY LTD

10.12 ORANGE STREET

LONDON, W.C. 2

Printed by T. and A. Constarle, Printers to His Majesty at the Edin burgh Univeraity Press 



